November 2000 • NREL/TP-580-28705

\title{
Environmental Life Cycle Implications of Using Bagasse- Derived Ethanol as a Gasoline Oxygenate in Mumbai (Bombay)
}

\author{
Kiran L. Kadam
}

Prepared for the National Energy Technology Laboratory Pittsburgh, Pennsylvania, USA and USAID, New Delhi, India
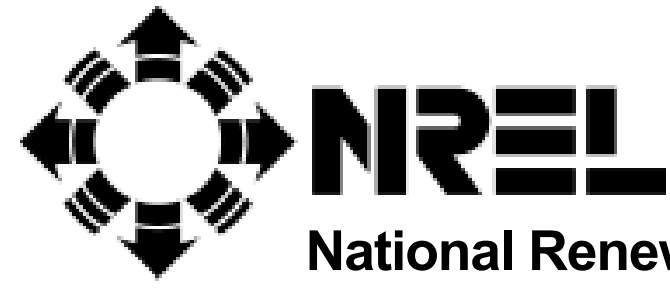

National Renewable Energy Laboratory

1617 Cole Boulevard

Golden, Colorado 80401-3393

NREL is a U.S. Department of Energy Laboratory

Operated by Midwest Research Institute $\bullet$ Battelle $\bullet$ Bechtel

Contract No. DE-AC36-99-G010337 
November $2000 \quad$ • NREL/TP-580-28705

\title{
Environmental Life Cycle Implications of Using Bagasse- Derived Ethanol as a Gasoline Oxygenate in Mumbai (Bombay)
}

\author{
Kiran L. Kadam
}

Prepared for the National Energy Technology Laboratory Pittsburgh, Pennsylvania, USA and USAID, New Delhi, India

Prepared under Task No. WG88.0101

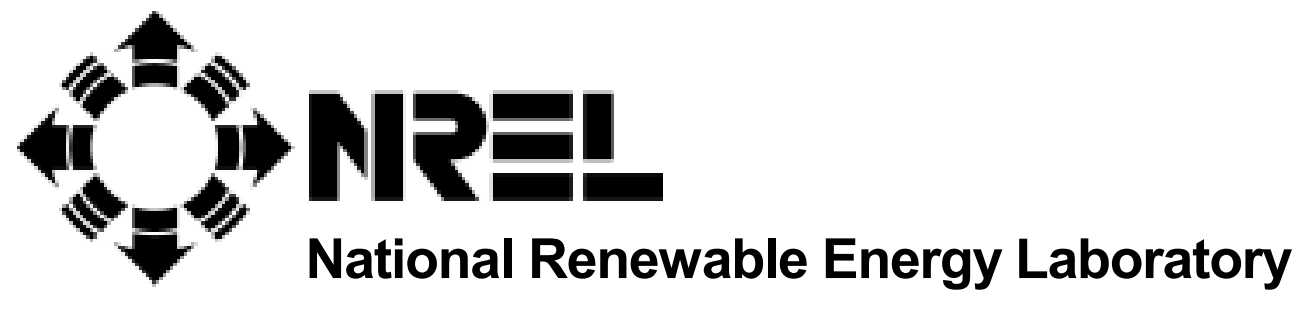

1617 Cole Boulevard Golden, Colorado 80401-3393

NREL is a U.S. Department of Energy Laboratory Operated by Midwest Research Institute $\bullet$ Battelle $\bullet$ Bechtel

Contract No. DE-AC36-99-G010337 


\section{NOTICE}

This report was prepared as an account of work sponsored by an agency of the United States government. Neither the United States government nor any agency thereof, nor any of their employees, makes any warranty, express or implied, or assumes any legal liability or responsibility for the accuracy, completeness, or usefulness of any information, apparatus, product, or process disclosed, or represents that its use would not infringe privately owned rights. Reference herein to any specific commercial product, process, or service by trade name, trademark, manufacturer, or otherwise does not necessarily constitute or imply its endorsement, recommendation, or favoring by the United States government or any agency thereof. The views and opinions of authors expressed herein do not necessarily state or reflect those of the United States government or any agency thereof.

Available electronically at http://www.doe.gov/bridge

Available for a processing fee to U.S. Department of Energy and its contractors, in paper, from:

U.S. Department of Energy

Office of Scientific and Technical Information

P.O. Box 62

Oak Ridge, TN 37831-0062

phone: 865.576 .8401

fax: 865.576.5728

email: reports@adonis.osti.gov

Available for sale to the public, in paper, from:

U.S. Department of Commerce

National Technical Information Service

5285 Port Royal Road

Springfield, VA 22161

phone: 800.553.6847

fax: 703.605.6900

email: orders@ntis.fedworld.gov

online ordering: http://www.ntis.gov/ordering.htm 


\section{TABLE OF CONTENTS}

Acknowledgments

$v i i$

Executive Summary

Background

Study Objective and Results

Next Phase of the Project

1 Introduction

2 Project Scope

3 Sugarcane and Sugar Production

3.1 World Sugar Situation

3.2 Sugarcane Production in India ___ 4

3.3 Sugar Industry in Maharashtra ___ 4

4 Bioethanol Production in Maharashtra _ 7

4.1 Ethanol Capacity _ 8

4.2 Bagasse Storage _ 8

5 Life Cycle Assessment __ 9

$5.1 \quad$ Related Research __ 9

5.2 Study Objective _ 9

5.3 Study Phases___ 9

5.4 Life Cycle Assessment Principles ___ 9

5.5 Methodology _ 11

5.5.1 Functional Unit 11

5.5.2 Definition of System Boundaries

5.5.3 Interpretation: Life Cycle Impact Assessment___ 12

6 Scoping Options and Decisions___ 12

6.1 Project Parameters 13

6.1.1 General System Boundaries _ 13

6.1.2 Environmental Issues Considered___ 14

6.1.3 Geographical Scope __ 16

6.1.4 Temporal Scope __ 17

6.2 Product Parameters__ 18

6.2.1 Scenarios 18

6.2.2 Functional Unit__ 18

6.3 Process Parameters __ 19

6.4 LCA-Specific Parameters __ 20

6.4.1 Allocation Rules__ 20 
6.5 Summary of Scoping Decisions and Approaches __ 20

$7 \quad$ Life Cycle Modeling__ 21

7.1 LCA Software__ 21

7.2 General Bagasse Data __ 21

7.3 Bagasse Burning__ 25

7.4 Ethanol Production _ 25

7.4.1 Enzymatic Process 26

7.4.2 Two-Stage Dilute Acid Process __ 28

7.4.3 Data Summary for Bagasse-to-Ethanol Processes __ 29

7.5 Sulfuric Acid Production__ 29

7.6 Ammonia___ 30

7.7 Lime__ 31

7.8 Electricity Production __ 31

7.9 Steam Production__ 31

7.10 Gasoline System _ 32

7.11 Gasoline and E10 Fuel Combustion

7.11.1 Tailpipe Emissions __ 32

7.11.2 Biomass versus Fossil Fuel $\mathrm{CO}_{2}$

$8 \quad$ Data Quality and Sources __ 34

8.1 Data Sources__ 34

8.2 Data Quality __ 35

9 Results and Discussion___ 36

9.1 Presentation of Results __ 36

9.2 Explanation of Negative Flows ___ 36

9.3 Hydrocarbon Emission __ 36

9.4 Time-Space Implications of Emissions___ 36

9.5 Life Cycle Energy Balance __ 36

9.6 LCI for Burning versus Diverting Bagasse to Ethanol: Enzyme Process ___ 38

9.6.1 Resource Depletion 40

9.6.2 Air Pollutants 40

9.6.3 Waste Generation 40

9.6.4 Energy Consumption and GHGs_ 40

9.7 LCI for Burning versus Diverting Bagasse to Ethanol: Dilute Acid Process __ 48

9.7.1 Resource Depletion__ 49

9.7.2 Air Pollutants 49

$\begin{array}{lll}9.7 .3 & \text { Waste Generation } & 49\end{array}$

9.7.4 Energy Consumption and GHGs__ 49

9.8 LCIA for Burning versus Diverting Bagasse to Ethanol __ 49

9.8.1 Greenhouse Potential — 50

9.8.2 Natural Resource Depletion Potential__ 50

9.8.3 Air Acidification Potential __ 51 
9.8.4 Eutrophication Potential _ 51

9.8.5 Human Toxicity Potential 54

9.8.6 Air Odor Potential______ 54

9.8.7 Maximum Incremental Reactivity Potential __ 54

10 Conclusion 56

$11 \quad$ Next Phase of the Project___ 57

List of Acronyms and Abbreviations _ 59

References__ 60

Appendix A: Project Review _ 63

Appendix B: Impact Assessment___ 64

Background __ 64

Overview of Life Cycle Impact Assessment Indices___ 66

Greenhouse Potential___ 66

Acidification Potential $\quad 66$

Eutrophication Potential _ $\quad 67$

Natural Resources Depletion Index___ 68

Human Toxicity Index _ـ 70

Stratospheric Ozone Depletion Index __ 74

Index Calculation — 74

Odor Index __ 76

Appendix C: List of Alcohol Manufacturers in Maharashtra __ 78 


\section{LIST OF TABLES}

Table 1. India's leading sugarcane-producing states 4

Table 2. Comparison of Maharashtra state and Indian national sugar statistics__ 6

Table 3. Number of sugar mills in India by cane crushing capacity___ 6

Table 4. Sugar factories in Maharashtra by geographical region -7

Table 5. Data for VSSK Ltd. 's sugar mill in Sangli, Maharashtra __ 7

Table 6. Environmental inventory flows considered __ 16

Table 7. Equivalency between current gasoline and E10 blend ___ 18

Table 8. Summary of scoping decisions and approaches ___ 21

Table 9. Proximate chemical composition of bagasse produced in Florida and Hawaii (oven-dry basis) __ _ 22

Table 10. Proximate chemical composition of commercially baled sugarcane bagasse (oven-dry basis) __ 23

Table 11. Calorific value and the elemental analysis for bagasse ___ 24

Table 12. Recent data on bagasse composition __ 24

Table 13. Changes in bagasse composition due to storage___ 24

Table 14. Data summary for bagasse-to-ethanol processes ___ 30

Table 15. Combustion-related properties of green feedstock and ligneous residues __ 30

Table 16. Overall emissions for current gasoline and E10 blend ___ 32

Table 17. Overview of change in emissions from low-level and high-level ethanol blends __ 33

Table 18. Apportioned emissions for E10 Blend____ 34

Table 19. Data sources and quality ___ 35

Table 20. Explanation of negative flows___ 37

Table 21. Life cycle inventory for burning versus diverting bagasse to ethanol: Summary for enzyme process _ 39

Table 22. Natural gas consumption and CODs for key modules ___ 39

Table 23. Life cycle inventory for burning versus diverting bagasse to ethanol: Summary for dilute acid process_ 48

Table 24. Life cycle impact assessment for burning versus diverting bagasse to ethanol: Summary for enzyme process

Table 25. Life cycle impact assessment for burning versus diverting bagasse to ethanol: Summary for dilute acid process

Table 26. Ozone-forming potential of selected compounds

Table 27. Greenhouse gas potential factors

Table 28. Acidification potential reactions _ 67

Table 29. Eutrophication potential factors__ 68 


\section{LIST OF FIGURES}

Figure 1. Geographical distribution of sugarcane production in India............................................................ 5

Figure 2. Schematic representation of extending system boundaries. .................................................................. 10

Figure 3. Elements of the scoping phase for life cycle analysis.................................................................... 13

Figure 4. General system boundaries for the comparison of burning of excess bagasse versus its diversion to ethanol

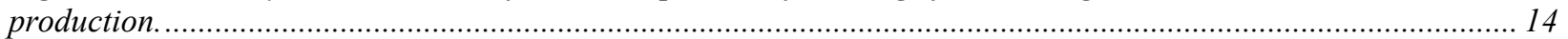

Figure 5. Energy and mass equivalency between current and future scenarios in the context of the functional unit. 19

Figure 6. Enzymatic process flow diagram................................................................................................ 26

Figure 7: Two-stage dilute-acid process flow diagram. ......................................................................... 28

Figure 8. Comparison of burning versus diverting bagasse to ethanol: Coal usage .......................................... 41

Figure 9. Comparison of burning versus diverting bagasse to ethanol: Natural gas usage ................................... 41

Figure 10. Comparison of burning versus diverting bagasse to ethanol: Crude oil usage. .................................... 42

Figure 11. Comparison of burning versus diverting bagasse to ethanol: Water usage.......................................... 42

Figure 12. Comparison of burning versus diverting bagasse to ethanol: Carbon monoxide emissions................... 43

Figure 13. Comparison of burning versus diverting bagasse to ethanol: Hydrocarbon (except methane) emissions. 43

Figure 14. Comparison of burning versus diverting bagasse to ethanol: Sulfur oxides $\left(\mathrm{SO}_{x}\right.$ as $\left.\mathrm{SO}_{2}\right)$ emissions...... 44

Figure 15. Comparison of burning versus diverting bagasse to ethanol: Nitrogen oxides $\left(\mathrm{NO}_{x}\right.$ as $\left.\mathrm{NO}_{2}\right)$ emissions.. 44

Figure 16. Comparison of burning versus diverting bagasse to ethanol: Particulate matter (unspecified) emissions.

Figure 17. Comparison of burning versus diverting bagasse to ethanol: Lead emissions. ..................................... 45

Figure 18. Comparison of burning versus diverting bagasse to ethanol: Fossil $\mathrm{CO}_{2}$ emissions............................ 46

Figure 19. Comparison of burning versus diverting bagasse to ethanol: Methane emissions. .............................. 46

Figure 20. Comparison of burning versus diverting bagasse to ethanol: Process energy usage ........................... 47

Figure 21. Comparison of burning versus diverting bagasse to ethanol: Nonrenewable energy usage.................... 47

Figure 22. Comparison of burning versus diverting bagasse to ethanol: Greenhouse effect potential..................... 52

Figure 23. Comparison of burning versus diverting bagasse to ethanol: Depletion of non-renewable resources..... 52

Figure 24. Comparison of burning versus diverting bagasse to ethanol: Air acidification potential....................... 53

Figure 25. Comparison of burning versus diverting bagasse to ethanol: Eutrophication potential........................ 53

Figure 26. Comparison of burning versus diverting bagasse to ethanol: Human toxicity potential. ........................ 55

Figure 27. Comparison of burning versus diverting bagasse to ethanol: Air odor potential. ................................. 55

Figure 28. Comparison of burning versus diverting bagasse to ethanol: EPA-Maximum incremental reactivity

potential.

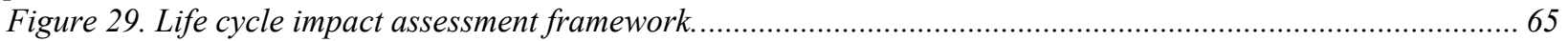




\section{ACKNOWLEDGMENTS}

This work was supported by the National Energy Technology Laboratory, Pittsburgh, PA, USA, and the U.S. Agency for International Development (USAID), New Delhi, India. The author wishes to thank these entities for financing the study and members of the Review Committee (see Appendix A) for their thoughtful review of this report and many useful comments and suggestions. Vince Camobreco of Ecobalance Inc. and John Sheehan of NREL deserve a special mention for their help throughout this project. 


\section{EXECUTIVE SUMMARY}

\section{Background}

Bagasse is the fibrous residue generated during sugar production and can be a desirable feedstock for fuel ethanol production. About $15 \%-25 \%$ of the bagasse is left after satisfying the mills' energy requirements, and this excess bagasse can be used in a bioconvesion process to make ethanol. It is estimated that a 23 million L/yr ( $\sim 6$ million gal/yr) ethanol facility is feasible by combining excess bagasse from three sugar mills in Maharashtra state. The annual gasoline consumption in Mumbai is estimated to be 400-500 million L, and the plant could supply about half of the ethanol demand, assuming that all gasoline is sold as an E10 fuel, a blend of 90\% gasoline and $10 \%$ ethanol by volume.

This study discusses the potential benefits of using bagasse-derived fuel ethanol in India. This strategy is pertinent to the Indian scene because it can: 1) reduce the net emissions of carbon dioxide, 2) improve air quality in major metropolitan areas such as Mumbai when used as an oxygenate additive to gasoline, 3) spur rural economic development, and 4) improve the country's energy security by reducing its reliance on foreign oil and associated risks.

\section{Study Objective and Results}

The study objective is to conduct a life cycle assessment (LCA) to quantify the environmental benefits of using bagasse-derived ethanol as a gasoline oxygenate in Mumbai. The LCA results would serve as a basis for deploying bagasse-to-ethanol production in Maharashtra, because positive environmental benefits - both in terms of local air quality and climate change - align with USAID's mission and objectives.

The LCA performed in this study demonstrates the potentially significant benefits of using ethanol derived from bagasse in Maharashtra. The overall results revealed a fundamental difference between Scenario 1 (burning excess bagasse as a disposal option) and Scenario 2 (conversion to ethanol) in terms of energy derived from renewable sources and the concomitant benefits of reduced greenhouse gas emissions. In particular, lower net values for the ethanol scenario were observed for the following:

- Carbon monoxide

- Hydrocarbons (except methane)

- $\mathrm{SO}_{\mathrm{x}}$ and $\mathrm{NO}_{\mathrm{x}}$

- Particulates

- Carbon dioxide and methane

- Fossil energy consumption

Hence, implementing the ethanol scenario would reduce air emissions and fossil energy consumption. Reduced carbon dioxide and methane emissions, although not regulated or mandated by state or national laws, are also desirable attributes. The lower greenhouse potential of Scenario 2 can be important if greenhouse gas trading is possible, or in the case of Joint 
Implementation because India is a developing country. Additional drivers are the lower values observed for the following six impact assessment categories for the ethanol scenario, when compared to the burning scenario:

- Greenhouse potential

- Depletion of natural resources

- Air acidification potential

- Eutrophication potential

- Human toxicity potential

- Air odor potential

Hence, the ethanol scenario distinguishes itself by demonstrating lower burdens than the burning scenario for key environmental criteria, both regulated and unregulated.

\section{Next Phase of the Project}

The next phase should address how to deploy this option in India by capitalizing on the environmental benefits of diverting the excess bagasse to ethanol production. The action plan would involve institutional and stakeholder networking and would address deployment this technology with the help of relevant parties in India, from both the public and private sectors.

Early this year, India's Minister of Petroleum and Natural Gas approved the use of ethanol as a fuel/additive. During his recent trip to India, President Clinton signed a joint statement on cooperation between India and the United States in the areas of energy and environment; the statement has language about Clean Development Mechanism as specified under the Kyoto Protocol. Hence, these recent developments in India portend a fertile ground for deploying the bioethanol option in India. 


\section{INTRODUCTION}

Worldwide economic development will lead to increased emissions of greenhouse gases (GHGs) well into the next century. Developing countries like India and China are expected to be major contributors to atmospheric carbon dioxide $\left(\mathrm{CO}_{2}\right)$ build-up and are potential targets for the deployment of biomass-based technologies, given the large amounts of biomass available within their borders.

India is the world's sixth largest and second fastest growing producer of greenhouse gases. In 1992, India's carbon emissions were 177 Mt (million metric tons), the third largest among nonOECD (Organization for Economic Cooperation and Development) countries. Fossil fuel energy consumption was about 7.5 quadrillion Btu, $15 \%$ of which was attributable to the transportation sector. About the same fraction of the total carbon emissions was associated with the transportation sector. Hence, significant carbon emissions arise from the use of fossil fuels for transportation in India. Vehicular emissions also contribute to local air pollution. Delhi, Mumbai (formerly Bombay), and Chennai (formerly Madras) are three of the world's ten most polluted cities. For the specific case of Mumbai, the National Environmental Engineering Research Institute in Nagpur, India, estimates that motor vehicles will contribute nearly $90 \%$ of the $255,000 \mathrm{t} / \mathrm{yr}$ of carbon monoxide (CO) emissions. Oxygenating the gasoline with ethanol can reduce $\mathrm{CO}$ emissions.

This report discusses the potential benefits of using bagasse-derived fuel ethanol, a strategy that is relevant to India, as it can: 1) reduce the net emissions of $\mathrm{CO}_{2}$ into the atmosphere, 2) improve air quality in major urban centers such as Mumbai when used as either a $10 \%$ (by volume) oxygenate additive to gasoline (short-term) or as an alternative to gasoline (long-term), 3) provide rural economic development, and 4) improve the country's energy security by reducing its exposure to risks associated with foreign oil.

\section{Project Scope}

The primary objective is to conduct a life cycle assessment (LCA) to quantify the environmental benefits of using bagasse-derived ethanol as a gasoline oxygenate in Mumbai. The LCA results will serve as a basis for deploying bagasse-to-ethanol production in Maharashtra, because positive environmental benefits - both in terms of local air quality and climate change - align with USAID's (U.S, Agency for International Development) mission and objectives. A brief discussion is also provided on how Joint Implementation (JI) and Clean Development Mechanism (CDM) initiatives and emissions trading, opportunities available to developing countries under the United Nations Framework Convention on Climate Change, can be used to help deploy bagasse-to-ethanol production India. 


\section{Sugarcane And Sugar Production}

\subsection{World Sugar Situation}

Brazil and India are the world's two largest sugarcane (Saccharum officinarum) growers with production of 300 and $285 \mathrm{Mt} / \mathrm{yr}$, respectively (Lower and Barros 1999; Singh 2000). These two countries are also expected to account for nearly $75 \%$ of the future increase in sugarcane production. World sugar consumption in 1999-2000 is estimated at $131.3 \mathrm{Mt}$, up $2 \%$ from the previous year's level, with Brazil and India contributing 19.0 and 17.9 Mt, respectively (World Bank 2000).

\subsection{Sugarcane Production in India}

As demonstrated in Table 1, India's leading sugarcane-producing states are Uttar Pradesh, Maharashtra, and Tamil Nadu, together accounting for about $70 \%$ of the national output (Smouse et al. 1998; Deccan Herald 1999). Although the focus of this study is Maharashtra, similar ethanol-producing facilities are possible in Uttar Pradesh and Tamil Nadu, and these could provide ethanol for an E10 blend, respectively, for Delhi and Chennai, the other two Indian cities to have the dubious distinction of being on the list of the world's 10 most polluted cities. The geographical distribution of this important crop for the entire country is shown in Figure 1 (USDA 1998).

Table 1. India's leading sugarcane-producing states

\begin{tabular}{l|cc|cc|cc}
\hline & \multicolumn{2}{|c|}{ 1989-1990 } & \multicolumn{2}{c|}{ 1995-1996 } & \multicolumn{2}{c}{ 1998-1999 $^{\text {a }}$} \\
\hline State & $\begin{array}{c}\text { Production, } \\
\text { Mt }\end{array}$ & $\begin{array}{c}\text { \%o of } \\
\text { Total }\end{array}$ & $\begin{array}{c}\text { Production, } \\
\text { Mt }\end{array}$ & $\begin{array}{c}\text { \%o of } \\
\text { Total }\end{array}$ & $\begin{array}{c}\text { Production, } \\
\text { Mt }\end{array}$ & $\begin{array}{c}\text { \%o of } \\
\text { Total }\end{array}$ \\
\hline Uttar Pradesh & 97.0 & 44.6 & 109.9 & 43.1 & NA & NA \\
Maharashtra & 34.0 & 13.5 & NA $^{\text {b }}$ & NA & 55.2 & 19.9 \\
Tamil Nadu & 21.9 & 11.2 & 13.1 & 12.3 & NA $^{\mathrm{b}}$ & NA $^{\mathrm{b}}$ \\
\hline
\end{tabular}

${ }^{\mathrm{a}}$ Estimates.

${ }^{\mathrm{b}}$ Not available.

\subsection{Sugar Industry in Maharashtra}

Maharashtra State is a leader in both agriculture and industrial growth in India. As shown in Table 1, Maharashtra is the second largest sugarcane producing state in India. Typical sugar industry statistics for Maharashtra are shown below (REPSO 1998).

- Annual average cane production: $40-45 \mathrm{Mt}$

- Average sugar recovery: $\quad 11.11 \mathrm{Mt}$

- Number of sugar mills: 109 (cooperatives)

A comparison of Maharashtra state with the country as a whole, in terms of key industry parameters for the last 5 years, is presented in Table 2 (Maharashtra State Govt. 1998). Table 3 
indicates that Maharashtra ranks second in India, based on the number of cane sugar mills (Maharashtra State Govt. 1998). However, in sugar production, it ranks first and surpasses even Uttar Pradesh, due to its high yield of sugar per $t$ of cane. Since 1987, a minimum capacity of 2,500 t crushed per day (TPD) has been imposed for new mills, and incentives are in place to encourage expansion of existing mills to 5,000 TPD (Winrock International 1993). Maharashtra has 12 and 6 mills with crushing capacities of >3,500 TPD and >5,000 TPD, respectively.

The southern and western Maharashtra regions have a greater share of cooperative sugar factories in the state. Table 4 offers regional distribution of sugar factories in Maharashtra (Maharashtra State Govt. 1998).

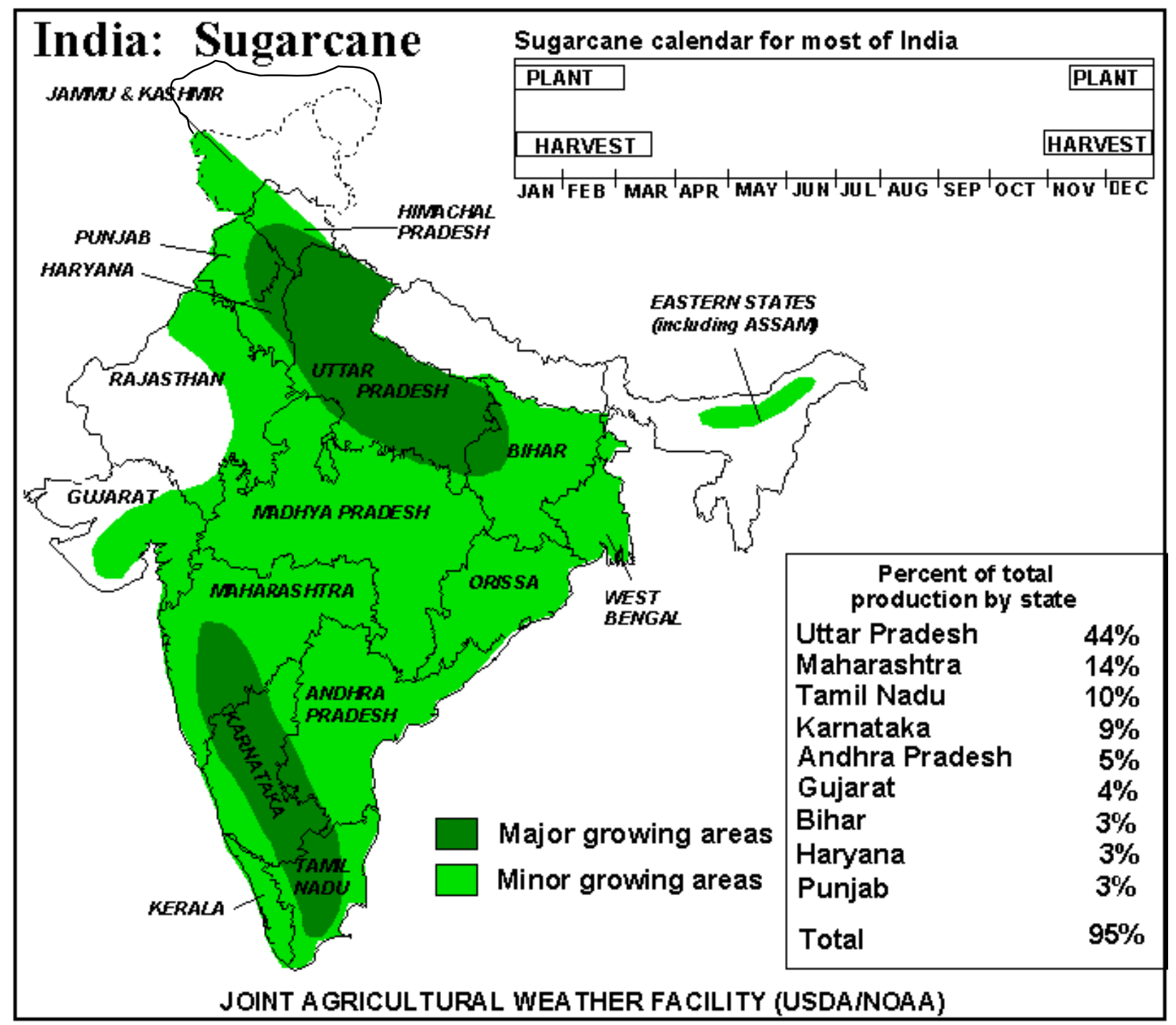

Figure 1. Geographical distribution of sugarcane production in India. 
Table 2. Comparison of Maharashtra state and Indian national sugar statistics

\begin{tabular}{|c|c|c|c|c|c|c|c|c|}
\hline & \multicolumn{4}{|c|}{ Maharashtra State $^{a}$} & \multicolumn{4}{|c|}{ India } \\
\hline & $\begin{array}{r}1993- \\
1994\end{array}$ & $\begin{array}{r}1994- \\
1995\end{array}$ & $\begin{array}{r}1995- \\
1996\end{array}$ & $\begin{array}{r}1996- \\
1997\end{array}$ & $\begin{array}{r}1993- \\
1994\end{array}$ & $\begin{array}{r}1994- \\
1995\end{array}$ & $\begin{array}{r}1995- \\
1996\end{array}$ & $\begin{array}{r}1996- \\
1997\end{array}$ \\
\hline $\begin{array}{l}\text { Sugarcane } \\
\text { cultivation, } \\
\text { ‘000 ha }\end{array}$ & $\begin{array}{r}344 \\
(10 \%) \\
\end{array}$ & $\begin{array}{r}519 \\
(14 \%) \\
\end{array}$ & $\begin{array}{r}580 \\
(14 \%) \\
\end{array}$ & $\begin{array}{r}516 \\
(12 \%) \\
\end{array}$ & 3422 & 3867 & 4147 & 4168 \\
\hline Yield, $\mathrm{t} / \mathrm{ha}$ & 81.1 & 85.5 & 80.4 & 81.0 & 67.1 & 71.3 & 67.8 & 66.5 \\
\hline $\begin{array}{l}\text { Sugarcane } \\
\text { production, } \mathrm{Mt}\end{array}$ & $\begin{array}{r}27.89 \\
(12 \%) \\
\end{array}$ & $\begin{array}{r}44.26 \\
(16 \%) \\
\end{array}$ & $\begin{array}{r}46.65 \\
(17 \%) \\
\end{array}$ & $\begin{array}{r}41.80 \\
(15 \%) \\
\end{array}$ & 229.66 & 275.54 & 281.10 & 277.25 \\
\hline $\begin{array}{l}\text { Crushing } \\
\text { capacity, } \\
\text { Mt }\end{array}$ & $\begin{array}{l}24.68 \\
(25 \%) \\
\end{array}$ & $\begin{array}{l}45.99 \\
(31 \%) \\
\end{array}$ & $\begin{array}{l}51.47 \\
(30 \%) \\
\end{array}$ & $\begin{array}{l}31.01 \\
(24 \%) \\
\end{array}$ & 98.33 & 147.64 & 174.72 & 130.38 \\
\hline $\begin{array}{l}\text { No. of sugar } \\
\text { mills }\end{array}$ & $\begin{array}{r}97 \\
(25 \%)\end{array}$ & $\begin{array}{r}107 \\
(26 \%)\end{array}$ & $\begin{array}{r}109 \\
(26 \%)\end{array}$ & $\begin{array}{r}105 \\
(26 \%)\end{array}$ & 394 & 408 & 416 & 412 \\
\hline $\begin{array}{l}\text { Average } \\
\text { recovery, \% } \\
\text { cane }\end{array}$ & 11.13 & 10.92 & 10.48 & 11.11 & 10.00 & 9.92 & 9.42 & 9.90 \\
\hline $\begin{array}{l}\text { Sugar } \\
\text { production, Mt }\end{array}$ & $\begin{array}{r}2.75 \\
(28 \%)\end{array}$ & $\begin{array}{r}5.02 \\
(34 \%)\end{array}$ & $\begin{array}{r}5.39 \\
(33 \%)\end{array}$ & $\begin{array}{r}3.44 \\
(27 \%)\end{array}$ & 9.83 & 14.64 & 16.45 & 12.90 \\
\hline
\end{tabular}

a\% numbers in parentheses represent Maharashtra's contribution to the national statistics.

Table 3. Number of sugar mills in India by cane crushing capacity

\begin{tabular}{l|ccccc|c}
\hline \multicolumn{1}{c|}{ State } & $\begin{array}{c}\text { TPD } \\
\mathbf{1 1 2 5 0}\end{array}$ & $\begin{array}{c}\text { TPD } \\
\mathbf{1 2 5 0}-\mathbf{2 5 0 0}\end{array}$ & $\begin{array}{c}\text { TPD } \\
\mathbf{2 5 0 0}-\mathbf{3 5 0 0}\end{array}$ & $\begin{array}{c}\text { TPD } \\
\mathbf{3 5 0 0}-\mathbf{5 0 0 0}\end{array}$ & $\begin{array}{c}\text { TPD } \\
\mathbf{> 5 0 0 0}\end{array}$ & $\begin{array}{c}\text { Total } \\
\text { Number } \\
\text { of Mills }\end{array}$ \\
\hline & \multicolumn{7}{c}{ Number of Mills at Specified Capacities } \\
Uttar Pradesh & 36 & 13 & 43 & 7 & 12 & 111 \\
Maharashtra & 39 & 17 & 35 & 12 & 6 & 109 \\
Andhra Pradesh & 20 & 3 & 9 & 1 & 3 & 36 \\
Tamil Nadu & 5 & 6 & 19 & 2 & 2 & 34 \\
Karnataka & 13 & 3 & 7 & 4 & 4 & 31 \\
Bihar & 15 & 10 & 3 & 0 & 1 & 29 \\
Gujarat & 6 & 1 & 6 & 2 & 4 & 19 \\
Punjab & 5 & 2 & 11 & 1 & 0 & 19 \\
Haryana & 4 & 2 & 3 & 1 & 1 & 11 \\
\hline
\end{tabular}


Table 4. Sugar factories in Maharashtra by geographical region

\begin{tabular}{lcc}
\hline Geographical Region & $\begin{array}{c}\text { Number of Sugar } \\
\text { Factories }\end{array}$ & $\begin{array}{c}\text { Installed Capacity, } \\
\text { TPD }\end{array}$ \\
\hline Total cooperatives & 81 & 209,650 \\
South and west & 78 & 204,600 \\
Central & 27 & 51,250 \\
Eastern & 19 & 21,250 \\
\hline
\end{tabular}

Table 5 lists data for Vasantdada Shetkari Sakhar Karkhana Ltd.'s (VSSK) sugar mill in Sangli, Maharashtra (Winrock International 1993; Smouse et al. 1998). The cane-crushing capacity at VSSK can be expanded to 7,500 TPD; however, mill management does not plan to expand beyond 6,000 TPD. This mill is considered as a typical candidate mill pertaining to ethanol production.

Table 5. Data for VSSK Ltd.'s sugar mill in Sangli, Maharashtra

\begin{tabular}{lc}
\hline Parameter & Value \\
\hline Mill capacity, TPD & 5000 \\
Cane crushed, t/year & 924,048 \\
Crop duration, days/year & 200 \\
Average cane crushing rate, TPD & 4,972 \\
Downtime, \% of milling season & 19.4 \\
Fiber, \% of cane & 13.7 \\
Bagasse, \% of cane & 30.8 \\
Moisture, \% of bagasse & 50.6 \\
Bagasse produced, t & 284,422 \\
\hline
\end{tabular}

\section{Bioethanol Production in Maharashtra}

Bagasse is the fibrous residue left after extraction of sugar from the cane and can be a good feedstock for bioethanol (i.e., biomass-derived ethanol) production. Bagasse is preferably used by the sugar mills for steam and power generation to satisfy internal needs; however, about $15 \%$ $25 \%$ of the bagasse is left after satisfying the mills' energy requirements, and this excess is not burned in the mill boilers. (Steam consumption in Indian sugar mills is as high as 50-55\% on cane compared to $40 \%$ in Hawaii. With improvements in or replacement of existing boilers, the excess bagasse figure could be higher.)

A bagasse-based ethanol project is in the planning/development stage in the United States. BC International (BCI) is adapting a non-operational molasses-to-ethanol plant in Jennings, Louisiana, to process local agricultural residue (USDOE 1998). This is a first stand-alone, commercial, biomass-to-ethanol plant and is expected to produce about 75 million L/yr (20 million gal) of ethanol a year from sugarcane bagasse and rice hulls as feedstock. This project is proceeding toward commercialization, and being an industrial-scale demonstration of the biomass-to-ethanol technology, it can be used as a model for a plant in Maharashtra. Such an 
ethanol plant could be centrally located to utilize bagasse from several sugar mills within a 50$\mathrm{km}$ radius.

\subsection{Ethanol Capacity}

Assuming that the typical sugar mill data in Table 5 apply, bagasse produced by a mill is about $285,000 \mathrm{t} / \mathrm{yr}$. If $20 \%$ of the bagasse is excess, then each mill has an extra 57,000 t/yr. If three mills combine their excess bagasse, $171,000 \mathrm{t} / \mathrm{yr}$ of bagasse is available for ethanol (at $50 \%$ moisture, 85,500 t/yr of dry bagasse). This corresponds to a 23 million L/yr (ca. 6 million gal/yr) ethanol facility, which is fairly large by Indian standards. The annual petrol (gasoline) consumption in Mumbai is estimated to be 400-500 million L. Thus, the plant could supply about half of the ethanol demand, assuming that all gasoline is sold as E10 fuel-a blend of 90\% gasoline and $10 \%$ ethanol by volume. If the other three large mills also contribute $20 \%$ of their bagasse, all the ethanol needed in Mumbai could be supplied by building a second plant, or a larger single plant.

Bagasse availability could be increased beyond the current levels via the following means (Rao 1997): 1) by introducing energy conservation measures in the sugar factories to reduce steam consumption, thereby reducing in-house bagasse usage, and 2) by substituting bagasse with other fuels in sugar factory boilers. One of the sugar factories in India is considering installing solar boilers. However, these measures are currently not in practice, and the increased bagasse availability is not assumed in this study.

An alternative feedstock that is available is cane trash, also known as cane residue or farm waste. For every $100 \mathrm{t}$ of clean sugarcane, about $28 \mathrm{t}$ of cane trash is left in the field and simply burned (Rao 1997). Based on this ratio, cane trash availability in Maharashtra alone can be estimated at approximately $16 \mathrm{Mt} / \mathrm{yr}$ (wet basis). However, the evaluation of cane trash for ethanol production is beyond the scope of this study.

\subsection{Bagasse Storage}

Crushing season for Maharashtra can be assumed as 200 days, running from October to May. Bagasse during the crushing season can be used as is, i.e., at $50 \%$ moisture. Whereas, for the rest of the 165 days, bagasse may need to be dried. Although bagasse drying with flue gases is an idea that is attractive in theory, it may not be feasible in India. Field experience in Hawaii has shown the potential for high maintenance and energy costs from parasitic power needed to operate the dryer and accessory equipment (Winrock International 1993). Solar drying is an attractive and potentially feasible option (Winrock International 1993, Rao 1997). Bagasse could be solar dried and stored before the onset of monsoon to last during the rainy season, which is finished by the beginning of the crushing season. A detailed discussion of this operation is beyond the scope of this analysis. An annual weighted-average moisture of $34 \%$ is used in process modeling. 


\section{Life CyCle Assessment}

\subsection{Related Research}

Biomass-derived ethanol has recently been the subject of life cycle analyses (NREL 1993, Wang et al. 1997, Wang et al. 1998). There has also been a series of studies estimating the life cycle energy balance of ethanol derived from corn (Morris and Ahmed 1992; Shapori et al. 1995). A recently completed study by Kadam et al. (1999) developed estimates of environmental flows, including air emissions, water effluents, solid waste, and the depletion of resources, associated with the disposal options for three types of biomass in California.

\subsection{Study Objective}

The objective of the current LCA study is to quantify and compare, over their life cycles, the comprehensive sets of flows to and from the environment (raw material and energy use, wastes, emissions, etc.) associated with the options of converting excess bagasse to ethanol versus discarding it as waste. Introduction of an E10 fuel blend (containing $10 \%$ bioethanol by volume) for motor vehicle use in Mumbai is compared with the gasoline currently being consumed. All of these flows are examined over the product life cycle, from production and extraction of raw materials through intermediate conversion processes, transportation, distribution, and use. Net life cycle energy consumption ("energy balance") is one component of the more comprehensive scope of an LCA such as undertaken in this study. Life cycle cost assessment is outside the scope of the current study.

\subsection{Study Phases}

The LCA study was divided into three phases as shown below; during each phase peer review was sought and comments were incorporated, when appropriate.

Phase I: Establish approach to LCA

Phase II: Develop database for LCA

Phase III: Conduct LCA

Step 1: Develop LCA models

Step 2: Generate final report

\subsection{Life Cycle Assessment Principles}

LCA is a technique for assessing the environmental aspects and potential impacts associated with a product, by:

- Compiling an inventory of relevant inputs and outputs of a system (life cycle inventory [LCI])

- Evaluating the potential environmental impacts associated with those inputs and outputs

- Interpreting the results of the inventory and impacts in relation to the objectives of the study. 
LCA studies the environmental aspects and potential impacts throughout a product's life (i.e., from cradle to grave) from raw material acquisition through production, use, and disposal. The general principle for extending the system boundaries, to include various processes involved in producing and using a product, is illustrated in Figure 2, although the boundaries may not all be relevant to the LCA of a transportation fuel.

In the most straightforward and transparent approach to LCI interpretation, the inventory results may be used as-is to help identify and prioritize opportunities for pollution prevention or increases in material and energy efficiency for processes within the life cycle. A particular advantage of LCI applied in this way is its comprehensiveness. LCAs help detect the shifting of environmental burdens from one life cycle stage to another (e.g., lower energy consumption during use, achieved at the cost of much higher manufacturing energy consumption), or from one medium to another (e.g., lower air emissions at the cost of increased solid waste).

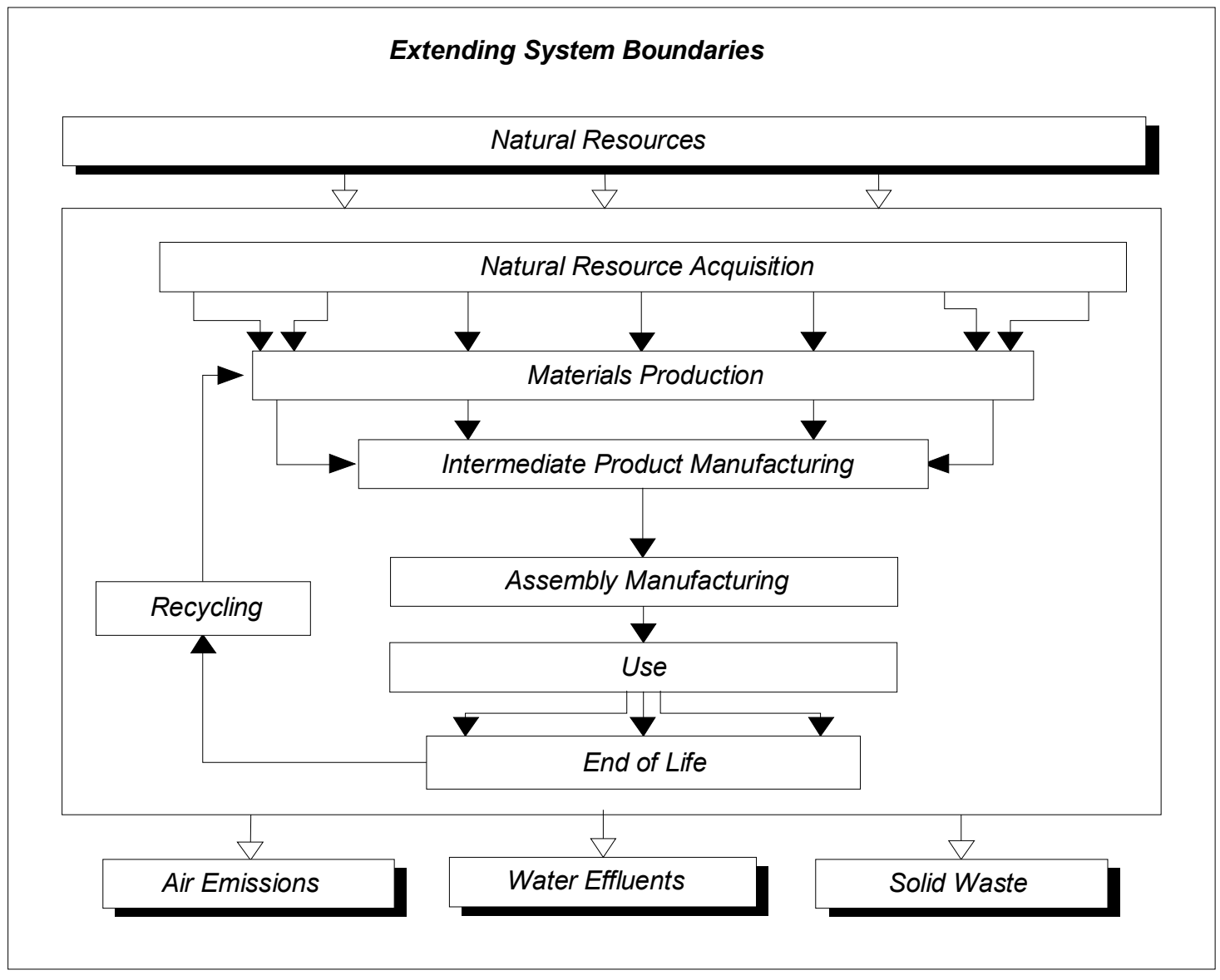

Figure 2. Schematic representation of extending system boundaries.

Because the number of flows calculated during an LCI analysis is often very large, subsets of the flows are sometimes consolidated or aggregated to facilitate interpretation, especially when two or more products or processes are being compared using LCA. This consolidation and aggregation of flows has been given the (perhaps misleading) name of life cycle impact 
assessment (LCIA). In fact, it is not the impacts of the environmental flows in the inventory that are estimated using LCIA. Instead, the inventory flows are consolidated and aggregated using information about their relative potential strength of influence on separate categories of potential environmental impacts, thereby generating indicators. The results within each LCIA impact category are useful for comparison of one product or process versus another, but have little meaning in an absolute sense (i.e., relative to estimating the actual environmental impacts of a product or process).

Because the results of an LCI and an LCIA are influenced by a significant number of assumptions and uncertainties, the interpretation phase usually includes some sensitivity analyses. This allows an assessment of the robustness of the baseline results, project assumptions, methodological choices, future scenarios, and uncertainties. In this study, data quality was assessed for its 1) precision, 2) completeness, 3) representativeness, 4) consistency, and 5) the origin of the data (measured, calculated, or estimated).

Principal aspects of LCI and LCIA are discussed briefly in the sections that follow. Further information about LCA methodology is provided in a number of publications from the Society of Environmental Toxicology and Chemistry (SETAC 1991; SETAC 1993a; SETAC 1993b; SETAC 1994), the U.S. Environmental Protection Agency (EPA) (EPA 1993a; EPA 1993b; EPA 1995a), the International Organization for Standardization (ISO 1996; ISO 1997), as well as other sources (Heijungs et al. 1992; SETAC-Europe 1992).

\subsection{Methodology}

\subsubsection{Functional Unit}

The comparison of different industrial systems can only be achieved if they perform the same function. Once this shared function is defined, a unit has to be chosen in order to compare the systems on the same quantitative basis. All the energy and mass flows in the inventory are normalized to this functional unit. Examples of how this is done are presented below.

- The comparison of different indoor paints (solvent-borne, water-borne, etc.) would be made on the following basis:

* Function: covering a surface

* Functional unit: the quantity of paint required to cover $5 \mathrm{~m}^{2}$ of wall (this function could be further refined to take into account secondary functions like opacity, washability, durability and lifetime, etc.)

- The comparison of different gasolines could be made on the following basis:

* Function: energy needed to travel $1 \mathrm{~km}$

* Functional unit: the quantity of gasoline or E10 fuel required to provide the necessary energy

\subsubsection{Definition of System Boundaries}

For each option being compared on a life-cycle basis, the corresponding systems are then determined (i.e., relevant processes to be included in the system are selected). The three main issues to address, for each of the systems, are discussed below. 
1) Exhaustivity of the systems. The LCA theoretical principle implies that each material and constituent be studied and traced back to natural resources, and forward through final disposal. The strict application of this principle would lead to the study of almost every industrial process, because all industrial operations work within a complex network. In order to focus LCA projects on the main operations, quantitative rules are applied to exclude the constituents and ancillary materials whose impacts are estimated to be negligible compared to those of the overall studied system.

2) Identification of steps/operations that are different from one system to another. As the project focuses on a comparison, steps that are functionally equivalent for the compared products could be excluded from both systems. On the other hand, steps or operations that are not functionally equivalent for the compared products should be taken into account, i.e., included in the system boundaries.

3) Identification of coproducts and determination of the appropriate partitioning parameter. This facilitates proper allocation to a defined product its share of the total pollution, energy consumption, and material flows for which the process is responsible.

\subsubsection{Interpretation: Life Cycle Impact Assessment}

In this element of the LCA, after the inventory has been prepared, there are two further steps that need to be considered:

1) Whether and how to aggregate and/or consolidate the inventory data using information about each flow's relative potential strength of influence with respect to separate categories of potential environmental impact; and

2) Whether and how to aggregate the results of the step mentioned above, across the impact categories considered.

Note that the first of these two steps is pursued in addition to the LCIA, not as a replacement for it. Those attempting to develop a final "score" for comparing products or processes only use the second of these two aggregation steps. It was not used in this project because it requires value judgements (e.g., is water pollution more sinister than air pollution?), which are beyond the scope of this analysis.

\section{SCOPING OPTIONS AND DECISIONS}

This section presents the various parameters that should be considered in order to precisely define the scope of the project. These parameters can be addressed sequentially, as indicated in Figure 3. The process begins by first considering "project" level parameters that involve highlevel choices that can have a profound impact on the general orientation and outcome of the project. These choices involve geographic, temporal, technical, and environmental aspects of the life cycle scenarios considered. Next, we need to consider more specific product parameters, including the exact nature and form of the products studied and the type of application in which they are used. The third group of parameters involves the production processes used to make the product. The types of choices made for high-level project parameters influence both product- 
and process-related parameters. Finally, there is a group of parameters that must be defined regarding the LCA methodology itself.

Subsequent sections address the separate scoping elements in turn, as follows:

$\begin{array}{lll}\text { Project Parameters } & \Rightarrow & \text { Section 6.1 } \\ \text { Product Parameters } & \Rightarrow & \text { Section 6.2 } \\ \text { Process Parameters } & \Rightarrow & \text { Section 6.3 } \\ \text { LCA-Specific Parameters } & \Rightarrow & \text { Section 6.4 }\end{array}$

The key criteria that have been employed in selecting an option for each parameter are:

- Relevance to the project's goals

- Availability of data

- Time and cost constraints

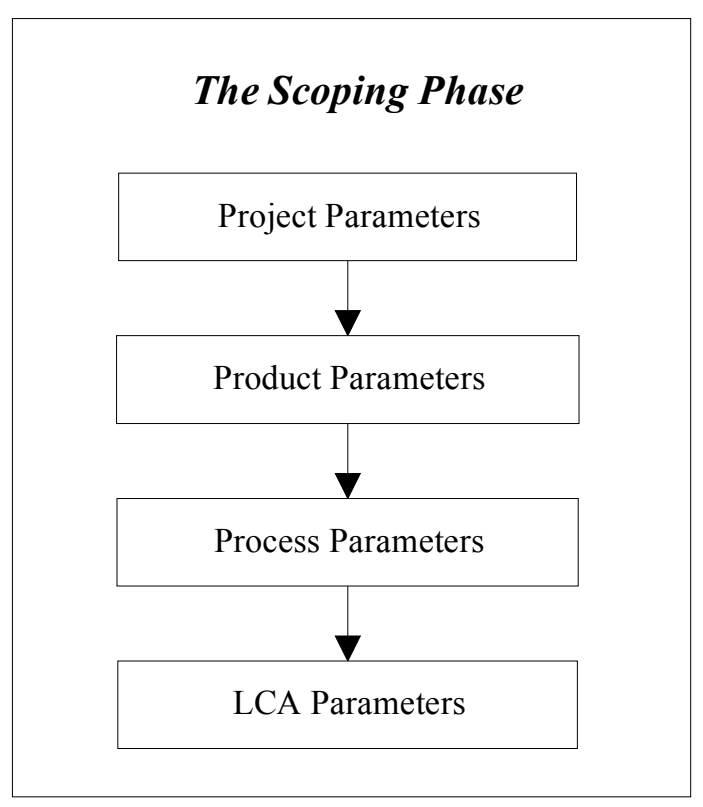

Figure 3. Elements of the scoping phase for life cycle analysis.

\subsection{Project Parameters}

\subsubsection{General System Boundaries}

Figure 4 shows the general system boundaries for the two scenarios considered in this study. In one scenario, bagasse is disposed of by burning (Scenario 1) and gasoline is used for transportation needs. In the alternative scenario, bagasse is converted into ethanol and used in reformulated gasoline (Scenario 2). Bagasse disposal by burning represents the status quo; this LCA compares bagasse conversion to ethanol with the status quo. 


\subsubsection{Environmental Issues Considered}

The LCA methodology traditionally calls for complete mass and energy balances for each process, including energy consumption, raw material consumption, air emissions, water effluents, and solid waste. This comprehensive compilation exercise results in a quantification of all existing flows into the environment. However, this scheme has become increasingly questionable because of the following reasons.

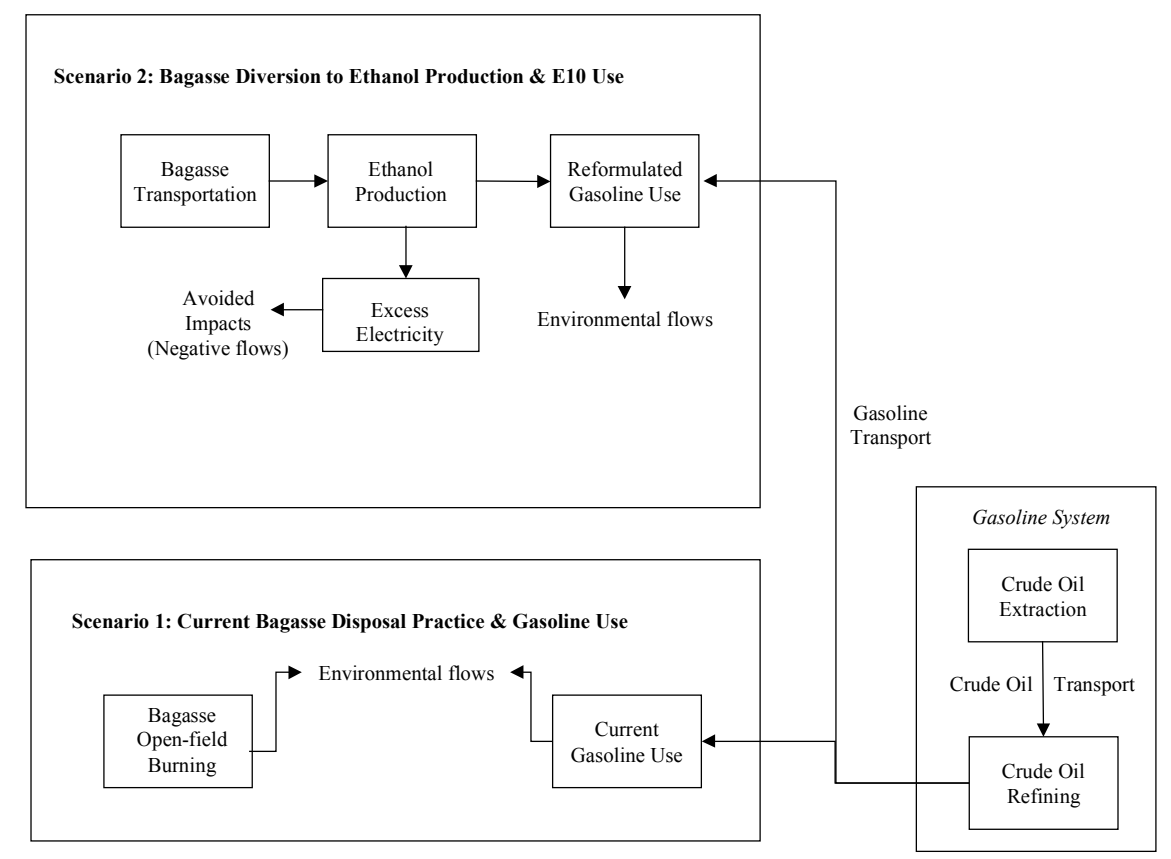

Figure 4. General system boundaries for the comparison of burning of excess bagasse versus its diversion to ethanol production.

- Practical Reasons: An ever-expanding number of parameters can be tracked within an inventory, reflecting more comprehensive data measurements. For instance, including U.S. Toxic Release Inventory (TRI) data would result in a list of approximately 200 pollutants being released during gasoline production. Similarly, including radionucleide emissions from electricity production would result in tracking more than 150 specific flows. Therefore, managing such a large inventory list adds to the complexity of carrying out as well as interpreting the LCA because these additional flows should be collected for all sources within the system for the sake of consistency.

- More Fundamental Reasons: By restricting the inventory data collection to the data actually needed in a subsequent decision analysis, a more focused LCA can be carried out, which ensures that the issues at stake receive the highest priority and data quality. Some studies even restrict their data collection to pollutants contributing to a single effect (e.g., greenhouse gases). 
Therefore, it is important to understand the issues or impacts that are of greatest concern to the users (or decision-makers) of the LCA and then tailor the data collection to meet their needs. It should be noted that an inventory number (e.g., quantity of lead) is only an indication of a potential impact. Additional data such as ambient concentration, pathways to human and ecological toxicity, and the existence of thresholds would be needed to assess the actual impact of this emission. These additional data are of the type required in risk assessment in which exposure data are collected for a few emissions at a single site. An actual LCA would need to gather these additional data for all inventory flows and for all sites included in the system boundaries (generally well over a hundred). Because the limitations of inventories are well known, this type of actual impact assessment is as difficult as it is impractical.

LCA should consequently be considered as providing an indication of potential environmental impact, complementary to actual impacts evaluated by other tools. The following steps were used to facilitate interpretation of the inventory results through impact assessment.

- Classification: The organization of inventory data into environmental impact and resource consumption categories, such as global warming potential, acidification potential, eutrophication potential, natural resource depletion, etc.

- Characterization: Weighted summing of inventory data within each environmental impact category, based upon each flow's relative strength of potential influence upon the identified environmental impact or effect

The characterization step takes explicit account of the latest scientific assessments of the uncertainty inherent in the equivalency factors, such as global warming potentials. In addition, the discussion accompanying the characterization results clearly states that the results of a characterization analysis serve strictly to normalize the multiple flows within the LCI with respect to a particular environmental issue in terms of their relative strength of potential contribution to that issue. Characterization is not in any way intended to estimate the actual impact of the emissions upon environmental issues.

Furthermore, some of the inventory flows themselves may be highly uncertain, with an estimable magnitude of uncertainty. This uncertainty is appropriately combined with the uncertainty inherent in the equivalency factors used in the characterization step. Table 6 indicates the environmental inventory flows and their corresponding impact assessment categories considered in this study.

Some of these environmental flows can potentially have impacts on the environment that go beyond the effects caused by just the flow itself. For this study, the potential impacts of the lifecycle flows have been assessed for the following impact assessment indicators: greenhouse effect potential, natural resource depletion, acidification potential, eutrophication potential, human toxicity potential, air odor potential, and ozone-forming potential.

To calculate the impact indicators, each flow that is determined to be a contributor to one of these categories is weighted according to its impact in comparison to a set baseline, e.g., for the greenhouse effect potential indicator, the baseline is grams of $\mathrm{CO}_{2}$ equivalent. The value for the flow is multiplied by this weighting factor to give an impact score for the particular flow. The

Environmental Life Cycle Implications of Using Bagasse-Derived Ethanol as a Gasoline Oxygenate in Mumbai (Bombay) 
impact scores for all contributing flows are then summed to give an overall impact score for potential impact. The weighting of the environmental flows is based upon the best available scientific knowledge; however, the score should be interpreted as potential impacts, not actual impacts. The exact methodology is discussed in more detail in Appendix B.

Table 6. Environmental inventory flows considered

\begin{tabular}{|c|c|}
\hline Environmental Flow & Associated Impact Category \\
\hline \multicolumn{2}{|l|}{ Natural Resources } \\
\hline Oil & Natural resources depletion 1 \\
\hline Coal & Natural resources depletion \\
\hline Natural Gas & Natural resources depletion \\
\hline $\begin{array}{l}\text { Other significant resources depending } \\
\text { on decision rules }\end{array}$ & Natural resources depletion \\
\hline \multicolumn{2}{|l|}{ Water Effluents } \\
\hline Chemical oxygen demand (COD) & Eutrophication potential \\
\hline Biological oxygen demand (BOD) & Eutrophication potential \\
\hline Nitrates & Eutrophication potential \\
\hline Phosphates & Eutrophication potential \\
\hline Total suspended solids & Direct use $^{\mathrm{a}}$ \\
\hline Metals & Direct use $^{\mathrm{a}}$ \\
\hline \multicolumn{2}{|l|}{ Air Emissions } \\
\hline $\mathrm{CO}_{2}$ & Greenhouse effect potential \\
\hline $\mathrm{CH}_{4}$ & Greenhouse effect potential \\
\hline $\mathrm{N}_{2} \mathrm{O}$ & Greenhouse effect potential \\
\hline $\mathrm{NO}_{\mathrm{x}}$ & Acidification potential \\
\hline $\mathrm{SO}_{\mathrm{x}}$ & Acidification potential \\
\hline Particulate & Direct use $^{\mathrm{a}}$ \\
\hline Hydrocarbons & Ozone-forming potential \\
\hline $\mathrm{CO}$ & Ozone-forming potential \\
\hline \multicolumn{2}{|l|}{ Solid Waste } \\
\hline Nonhazardous & Direct use $^{\mathrm{a}}$ \\
\hline Hazardous & Direct use $^{\mathrm{a}}$ \\
\hline \multicolumn{2}{|l|}{ Energy Use } \\
\hline Total primary energy & Direct use $^{\mathrm{a}}$ \\
\hline Process energy & Direct use $^{\mathrm{a}}$ \\
\hline Fossil fuel energy & Direct use $^{\mathrm{a}}$ \\
\hline
\end{tabular}

\subsubsection{Geographical Scope}

The focus of the project is the use of excess bagasse in Maharashtra state and the use of E10 gasoline in Mumbai, Maharashtra. However, the geographic scope of particular data items

\footnotetext{
${ }^{1}$ Inflows such as sand, limestone, etc. could be used in the natural resources depletion index although their impact is negligible because of their abundance in nature.
} 
pertains to whatever locations are dictated by actual plant locations, feedstock origins, sources of electricity, etc.

\subsubsection{Gasoline System}

In 1993, no unleaded gasoline was available in India. In that year, the $3.5 \mathrm{Mt}$ of leaded gasoline used in India contained 0.56 grams of lead per liter $(\mathrm{g} \mathrm{Pb} / \mathrm{L})$ (Earth Summit Watch 1995). The Government of India has adopted a program to introduce unleaded petrol in a phased manner. The plan proposes to reduce the maximum lead content in petrol to $0.15 \mathrm{~g} \mathrm{~Pb} / \mathrm{L}$. The Government is also undertaking a program for production of unleaded petrol at specific refineries, which could be supplied to Delhi and Mumbai in the initial phase.

The desirability of removing lead from gasoline is clear, and the EPA and the World Bank have discussed several aspects of this issue (EPA 1985; Lovei 1996; World Bank 1998). Supplying unleaded petrol throughout all of India may be possible with the commissioning of new refineries by 2005 . India is one of the 10 countries that are the most likely candidates for phasing out the use of lead in gasoline by 2005 but that have not yet made firm decisions to do so (Earth Summit Watch 1999). Because there is no official commitment yet to adopt unleaded gasoline, leaded gasoline was assumed to be the "current gasoline" in this analysis.

The production and combustion of reformulated leaded gasoline, E10 fuel (10\% ethanol and 90\% leaded gasoline), was assumed to occur in Maharashtra. Currently, there is no biomass-derived ethanol being produced in India, and gasoline data from India is not readily available. Hence, surrogate data were used in the analysis. Leaded gasoline data was from Ecobalance Inc.'s database for European leaded gasoline production and use.

\subsubsection{Ethanol System}

The biomass used to make ethanol is of Maharashtra origin, and ethanol production is assumed to also occur in Maharashtra. However, for modeling purposes, U.S. average data are used. Data on ancillary materials needed for biomass to ethanol conversion was based on a U.S. average situation. The combustion of the E10 blend was assumed to follow an emissions profile based on Canadian Renewable Fuels Association data (CRFA 1999).

\subsubsection{Electricity Production}

Electricity production was based on Ecobalance Inc.'s data for India. This database was considered to be applicable to electricity production in Maharashtra.

\subsubsection{Temporal Scope}

The issue here is whether to study a current situation, or to model a future situation, or to model both current and future scenarios. Current and future scenarios could be quite different. For example, current scenarios would be limited to existing ethanol production technology as well as existing transportation vehicle scenarios and biomass availability scenarios.

One reason for studying a mid- to long-term time frame, is that a widespread use of biomassderived ethanol in the very near term is not probable. However, the results of this study are datadriven, and the use of forecast or modeled (rather than current, empirically based) production, conversion, and end-use technology parameters would greatly increase the uncertainty in the 
final results. For this study, the middle part of the decade has been selected as the production period.

\subsection{Product Parameters}

\subsubsection{Scenarios}

Sugar mills generally use the boilers as incinerators to get rid of their bagasse. However, after satisfying their energy needs, the leftover bagasse is essentially a waste stream. Excess bagasse, which is $15 \%-25 \%$ of the total generated, is usually burned on the land, i.e., open-field burned (Wayman and Parekh 1990). All the three Indian mills in the USAID study considered excess bagasse as a problem (Winrock International 1993), and they currently operate under conditions where excess bagasse causes operational problems of storage and handling with no economic benefits as an energy source. Also, the same study mentions decomposing as a current alternative for bagasse disposal. Hence, it is reasonable to set decomposition or open-field burning as an existing scenario representing the status quo; the latter is used as the existing disposal mode in this study. Diversion of excess bagasse to ethanol production represents the alternative scenario.

\subsubsection{Functional Unit}

The functional unit of this study is the disposal of a defined amount of bagasse, i.e., 1 dry $t$. Bagasse-derived ethanol is used in reformulated gasoline (E10), which replaces current gasoline on an energy-equivalent basis. The equivalency between current gasoline and E10 blend is explained in Table 7. The environmental burdens are calculated on a differential basis in the case of gasoline. This approach is explained in section 5.5.2 on Definition of System Boundaries. The gasoline burdens of both the scenarios are reduced by the amount of gasoline required in the ethanol scenario. This is further illustrated in

Figure 5.

Table 7. Equivalency between current gasoline and E10 blend

\begin{tabular}{lcc}
\hline & Current Gasoline & E10 Blend \\
\hline Heating value, $\mathrm{MJ} / \mathrm{L}$ & 31.1 & 30.1 \\
Oxygen content, wt \% & 0 & 3.50 \\
Density, kg/L & 0.750 & 0.754 \\
Weight fraction ethanol & 0 & 0.105 \\
Weight fraction gasoline & 1 & 0.895 \\
Volume to achieve 31.1 MJ, L & 1.000 & 1.035 \\
Total fuel, kg & 0.750 & 0.780 \\
Gasoline, $\mathrm{kg}$ & 0.750 & 0.698 \\
Ethanol, $\mathrm{kg}$ & 0.000 & 0.082 \\
\hline \multicolumn{2}{c}{ En a differential basis: } & $1 \mathrm{~kg}$ ethanol equivalent to: $0.633 \mathrm{~kg}$ current gasoline \\
\hline
\end{tabular}




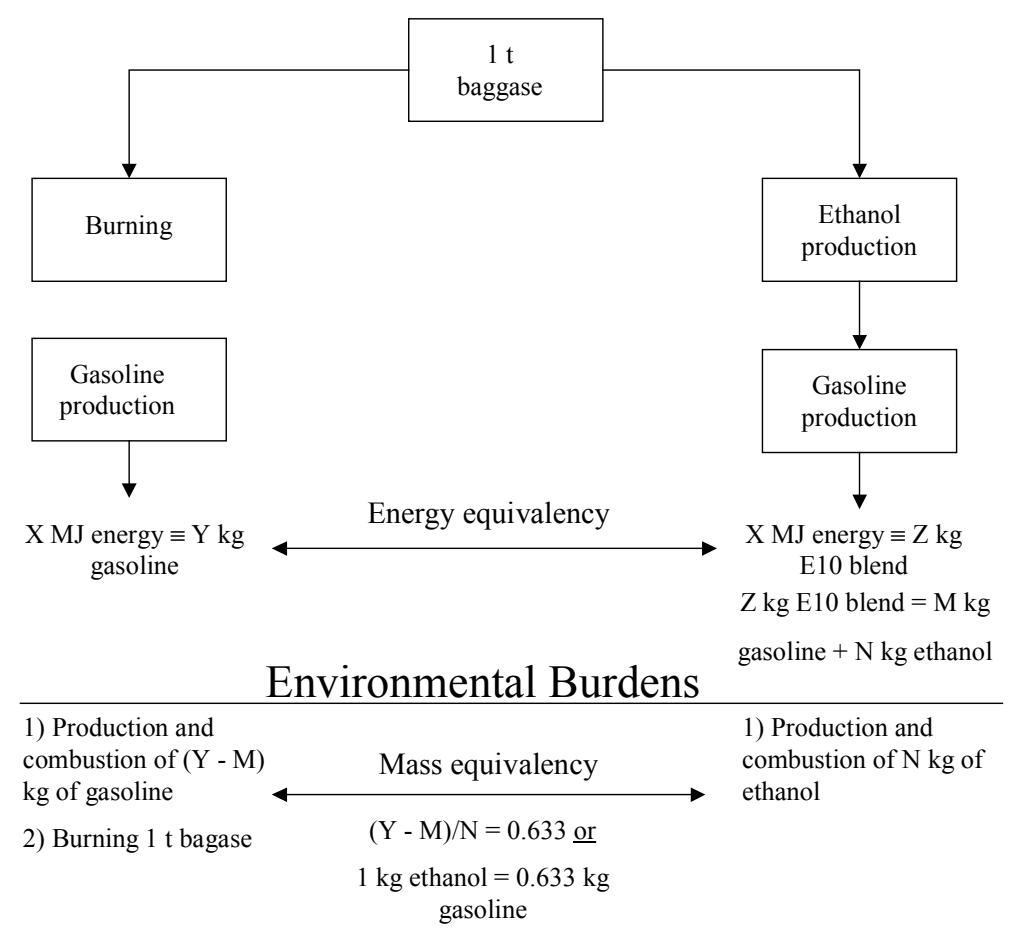

Figure 5. Energy and mass equivalency between current and future scenarios in the context of the functional unit.

\subsection{Process Parameters}

Process parameters are strongly affected by the choices made on the project-related and productrelated parameters. For example, the assumption of using technology based on the middle part of the decade for all processes leads to a number of conclusions about fuel production and feedstock supplies.

Feedstock for gasoline is crude oil produced domestically and imported from foreign countries. Data characterizing the split between foreign and domestic crude oil supplies to fuel production were used, with regional differences taken into account. Given that the data were from the United States or Europe, "domestic" refers to these locations.

For the ethanol scenario, two ethanol production processes were evaluated: an enzyme-based process and a dilute-acid-based process. BC International is adapting an existing (nonoperational) molasses-to-ethanol plant in Jennings, Louisiana to process local agricultural residues using a dilute-acid process. The dilute-acid process can be a near-term option because it does not involve enzyme production, which is considered a longer-term process at this juncture. 


\subsection{LCA-Specific Parameters}

\subsubsection{Allocation Rules}

The production of both fuel ethanol and gasoline generates other products, which are recovered and used in other product systems. They are considered coproducts. The problem is the apportioning or allocating of energy resources, raw materials, pollutants, etc. from the common production steps to the product studied (fuels) and the coproducts. Inputs and outputs of the common steps can be partitioned across the coproducts on various bases, including (for example):

- Mass

- Dry mass

- Energy content

For this analysis, there were two main processes that required allocation. Crude oil refining produces a number of petroleum products. This study was mainly interested in one of those products, namely gasoline. Allocation of the refinery energy use and emissions was done on an energy basis. Another process that required allocation was ethanol production. The production of ethanol also produces lignin as a coproduct, which can be used as an energy source. The allocation technique used in the study was to expand the system boundaries to include the use of the lignin residue for on-site cogeneration. In this way the emissions from an alternate energy production method were offset by the use of the lignin. These offset emissions were accounted for as negative values in the life cycle.

\subsubsection{Modeling Biomass-Based $\mathrm{CO}_{2}$ Emissions}

The carbon in the biomass portion of the ethanol is derived from the $\mathrm{CO}_{2}$ absorbed by plants during photosynthesis. These carbon atoms are released at the end of the products' life, predominantly in the form of $\mathrm{CO}_{2}$, but also in the form of $\mathrm{CO}$, hydrocarbons or methane $\left(\mathrm{CH}_{4}\right)$ molecules. These carbon releases are offset (though not all at the same rate) by the $\mathrm{CO}_{2}$ uptake or sequestering during plant growth. A distinction was made between net carbon emissions from the production and subsequent combustion of biomass products and carbon emissions from the combustion of fossil fuels. The carbon uptake by plants was accounted for as a credit. Only fossil $\mathrm{CO}_{2}$ is used in estimating greenhouse potential.

\subsection{Summary of Scoping Decisions and Approaches}

Table 8 summarizes the scoping decisions and approaches used in this project, which were described in the previous sections 6.1 through 6.4 . 
Table 8. Summary of scoping decisions and approaches

\begin{tabular}{lll}
\hline Element & Parameter Type & Decision or Approach \\
\hline$\underline{\text { Project }}$ & Spatial & Biomass: Maharashtra \\
& & Fuel production: Worldwide \\
& & Fuel use: Maharashtra \\
& Temporal & 2005 \\
\hline$\underline{\underline{\text { Product }}}$ & Biomass & Bagasse \\
& Current disposal & Burning \\
& alternative & \\
& Functional Unit & Conversion of 1 dry t of bagasse to ethanol \\
\hline$\underline{\text { Process }}$ & Ethanol & Bioconversion technology: 1) dilute acid pretreatment, \\
& & followed by enzyme hydrolysis/fermentation or 2) \\
& & two-stage dilute acid hydrolysis followed by \\
& & fermentation \\
& Gasoline & Feedstock: domestic plus imported crude oil \\
& Electricity & Refining: 2005 \\
\hline$\underline{\text { LCA }}$ & Coproduct allocation & Electricity production for India (average) \\
& & Energy based for petroleum products \\
& & Expansion of system boundaries to include lignin residue \\
& Interpretation & use for on-site cogeneration \\
& & Classification and characterization \\
& & Perform sensitivity analysis, if necessary, on uncertain or \\
& & variable input parameters \\
\hline
\end{tabular}

\section{LIFE CyCLE MOdeling}

\subsection{LCA Software}

The TEAM ${ }^{\mathrm{TM}}$ software (version 3.0) developed by Ecobalance Inc. (Bethesda, Maryland) was used in this analysis.

\subsection{General Bagasse Data}

Proximate chemical compositions, of both unbaled and commercially baled, bagasse produced in Florida, Hawaii, and Louisiana are given in Table 9 and Table 10. This data collected by Atchison (1993) is old but still useful.

The calorific value and the elementary analysis for bagasse are shown in Table 11. Recent data on bagasse composition, both from the literature (Johnson et al. 1992) and this study (based on NREL laboratory analysis), are provided in Table 12. Both sets of data agree quite well with each other. Johnson et al. (1992) also studied the changes in bagasse composition due to storage; their data, shown in Table 13, does not predict significant sugar loss. In this analysis no change in bagasse composition upon storage is assumed. 
Table 9. Proximate chemical composition of bagasse produced in Florida and Hawaii (oven-dry basis)

\begin{tabular}{|c|c|c|c|c|c|c|c|c|c|c|}
\hline \multirow[b]{2}{*}{ Variety } & \multirow[b]{2}{*}{ Source } & \multirow[b]{2}{*}{$\begin{array}{l}\text { Crop } \\
\text { Year }\end{array}$} & \multirow[b]{2}{*}{$\begin{array}{l}\text { Ash } \\
\%\end{array}$} & \multirow[b]{2}{*}{$\begin{array}{l}\text { Lignin } \\
\%\end{array}$} & \multirow[b]{2}{*}{$\begin{array}{l}\text { Pentosans }{ }^{\mathrm{a}} \\
\%\end{array}$} & \multicolumn{3}{|c|}{ Solubility in } & \multirow{2}{*}{$\begin{array}{l}\text { Cross \& } \\
\text { Bevan } \\
\text { Cellulose } \\
\%\end{array}$} & \multirow[b]{2}{*}{$\begin{array}{l}\text { Alpha- } \\
\text { cellulose }^{b} \\
\%\end{array}$} \\
\hline & & & & & & $\begin{array}{l}\text { Hot } \\
\text { Water } \\
\%\end{array}$ & $\begin{array}{l}\text { Alcohol } \\
\text { Benzene } \\
\%\end{array}$ & $\begin{array}{l}1 \% \\
\text { NaOH } \\
\%\end{array}$ & & \\
\hline \multicolumn{11}{|l|}{ Florida } \\
\hline- & Clewiston & 1948 & 2.2 & 18.1 & 27.9 & 11.2 & 10.8 & 39.9 & 52.0 & 33.7 \\
\hline CI.41-223 & Clewiston & 1952 & 1.0 & 18.2 & 26.6 & 15.1 & 7.0 & 40.7 & 48.0 & 30.6 \\
\hline F.31-436 & Clewiston & 1952 & 1.6 & 16.4 & 27.4 & 15.5 & 6.4 & 43.2 & 48.8 & 30.8 \\
\hline F.31-962 & Clewiston & 1952 & 2.2 & 18.6 & 28.7 & 9.8 & 8.0 & 40.0 & 49.0 & 31.5 \\
\hline Mean & & & 1.8 & 17.8 & 27.6 & 12.9 & 8.0 & 41.0 & 49.4 & 31.6 \\
\hline \multicolumn{11}{|l|}{$\overline{\text { Hawaii }}$} \\
\hline 8560 & & 1952 & 5.4 & 21.3 & 27.7 & 5.7 & 3.2 & 33.9 & 50.2 & 31.8 \\
\hline- & Laupahoehoe & - & 1.9 & 22.5 & 31.2 & 3.4 & 2.1 & 31.4 & 55.4 & 34.3 \\
\hline 1933 & Ewa & - & 2.6 & 19.3 & 31.3 & 4.0 & 3.6 & 31.3 & 55.0 & 31.6 \\
\hline 1933 & Oahu & - & 3.3 & 20.1 & 31.0 & 2.7 & 3.4 & 32.0 & 52.0 & 31.7 \\
\hline Mean & & & 3.3 & 20.8 & 30.3 & 4.0 & 3.1 & 32.2 & 53.2 & 32.4 \\
\hline
\end{tabular}

${ }^{\mathrm{a}}$ Pentosans $=$ furfural $\mathrm{x}$ factor 0.8 .

${ }^{\mathrm{b}}$ Corrected for pentosans and ash, basis original material.

Source: "Pulp \& Paper Prospects in Latin America," pp. 294-314, United Nations, NY, 1955; and USDA Mimeo Circ. ARS-71-4, March 1955. 
Table 10. Proximate chemical composition of commercially baled sugarcane bagasse (oven-dry basis)

\begin{tabular}{|c|c|c|c|c|c|c|c|c|c|}
\hline \multirow[b]{2}{*}{$\begin{array}{l}\text { Source \& } \\
\text { Condition }\end{array}$} & \multirow[b]{2}{*}{$\begin{array}{l}\text { Crop } \\
\text { Year }\end{array}$} & \multirow[b]{2}{*}{$\begin{array}{c}\text { Ash } \\
\%\end{array}$} & \multicolumn{3}{|c|}{ Solubility in } & \multirow[b]{2}{*}{$\begin{array}{c}\text { Lignin } \\
\% \%\end{array}$} & \multirow[b]{2}{*}{$\begin{array}{c}\text { Pentosans } \\
\%\end{array}$} & \multirow{2}{*}{$\begin{array}{c}\text { Cross \& } \\
\text { Bevan } \\
\text { Cellulose } \\
\%\end{array}$} & \multirow[b]{2}{*}{$\begin{array}{c}\text { Alpha- } \\
\text { Cellulose } \\
\%\end{array}$} \\
\hline & & & $\begin{array}{c}\text { Alcohol } \\
\text { Benzene } \\
\%\end{array}$ & $\begin{array}{c}\text { Hot } \\
\text { Water } \\
\%\end{array}$ & $\begin{array}{c}1 \% \\
\text { NaOH } \\
\%\end{array}$ & & & & \\
\hline $\begin{array}{l}\text { Lockport, LA, } \\
\text { Baled, stored } \\
9 \text { months }\end{array}$ & 1941 & 2.9 & 1.7 & 4.0 & 32.9 & 21.3 & 29.4 & 58.4 & 36.8 \\
\hline Stored & 1937 & 1.8 & 1.7 & - & - & 26.6 & 29.1 & 60.2 & 43.1 \\
\hline Stored & 1940 & 6.3 & 4.0 & 9.1 & 36.1 & 19.6 & 28.4 & 55.0 & 40.6 \\
\hline $\begin{array}{l}\text { Houma, LA, } \\
\text { dried } \\
\text { immediately, } \\
\text { baled, } \\
\text { represents } \\
\text { fresh bagasse }\end{array}$ & 1941 & 2.4 & 6.0 & 8.1 & 35.9 & 18.9 & 30.0 & 53.3 & 33.4 \\
\hline $\begin{array}{l}\text { Clewiston, FL, } \\
\text { freshly dried, } \\
\text { dry-screened }\end{array}$ & 1948 & 2.2 & 3.5 & 11.2 & 39.9 & 18.1 & 28.5 & 52.0 & 33.7 \\
\hline
\end{tabular}


Table 11. Calorific value and the elemental analysis for bagasse

\begin{tabular}{lc}
\hline \multicolumn{1}{c}{ Parameter } & Value (dry basis) \\
\hline Calorific value & $18,950 \mathrm{~kJ} / \mathrm{kg}$ \\
Carbon & $47.0 \%$ \\
Hydrogen & $5.5 \%$ \\
Nitrogen & $1.7 \%$ \\
Sulfur & $0.1 \%$ \\
Oxygen (by difference) & $45.7 \%$ \\
\hline
\end{tabular}

Table 12. Recent data on bagasse composition

\begin{tabular}{lcc}
\hline $\begin{array}{c}\text { Feedstock } \\
\text { Component }\end{array}$ & $\begin{array}{c}\text { Johnson et al. (1992) } \\
\text { Dry wt \% }\end{array}$ & $\begin{array}{c}\text { Current Study-Hawaiian Bagasse } \\
\text { Dry wt \% }\end{array}$ \\
\hline Glucan & 41.0 & 40.6 \\
Galactan & 0.5 & 0.8 \\
Mannan & 0.4 & 0.2 \\
Xylan & 23.2 & 20.0 \\
Arabinan & 2.2 & 1.7 \\
Lignin & 24.3 & 25.5 \\
Extractives & 3.8 & 1.8 \\
Ash & 2.6 & 3.7 \\
Uronic acids & 2.3 & 5.7 \\
Total & 100.3 & 100.0 \\
\hline
\end{tabular}

Table 13. Changes in bagasse composition due to storage

\begin{tabular}{lc|ccc}
\hline \multicolumn{1}{c}{ Components } & Composition $^{\mathbf{a}}$ & \multicolumn{3}{c}{ \% Change Compared to Day Zero $^{\mathbf{b}}$} \\
\hline & Day Zero & Pile Center & Crust & Compost \\
Extractives $^{\mathrm{c}}$ & $3.8 \pm 0.1$ & -2.1 & $<2$ & +9.2 \\
Ash $^{\mathrm{c}}$ & $2.6 \pm 0.1$ & $<0.2$ & +2.1 & +3.5 \\
Composition Data on an Extractives- $^{\text {free Basis }}$ & & & & \\
Total Lignin & & & & \\
Uronic Acids & & & & \\
Arabinan & $24.3 \pm 0.3$ & +0.5 & +0.8 & +8.6 \\
Xylan & $2.3 \pm 0.7$ & $<1.1$ & $<1.1$ & -1.4 \\
Mannan & $2.2 \pm 0.1$ & -0.5 & -0.5 & -0.8 \\
Galactan & $23.2 \pm 0.4$ & +0.6 & -1.9 & -10.6 \\
Glucan & $0.4 \pm 0.1$ & $<0.1$ & +0.1 & $<0.1$ \\
Mass Closure & $0.5 \pm 0.03$ & $<0.1$ & $<0.1$ & -0.2 \\
& $41.0 \pm 1.0$ & +3.0 & -2.1 & -3.0 \\
\hline
\end{tabular}

${ }^{\mathrm{a}} \mathrm{Wt} \%$ on an oven-dried basis.

${ }^{\mathrm{b}}$ Significant at the $95 \%$ confidence level.

${ }^{\mathrm{c}}$ Contents determined on a whole biomass basis for the $-20 /+80$ mesh fraction.

${ }^{\mathrm{d}}$ Total lignin and other insoluble materials including condensed proteins, but not ash. 


\subsection{Bagasse Burning}

As mentioned earlier, the standard disposal option for bagasse was determined to be burning, which represents the status quo. Because no data were available for bagasse burning, a surrogate data set was used. The air emissions were calculated using emission factors provided by the EPA (EPA 1995b) for biomass burning. Sulfur dioxide and carbon dioxide emissions for each scenario were based on the estimated sulfur and carbon contents, respectively, of green feedstock and ligneous residues. The reason for deviating from the EPA data for sulfur dioxide emissions is the relatively high sulfur content of bagasse.

\subsection{Ethanol Production}

Ethanol production from corn or molasses is a well-established technology with several plants located in the Midwestern United States and Brazil. Using lignocellulosic biomass as a substrate to make ethanol is also a promising approach. Many sources of lignocellulosic biomass, such as agricultural residues, forestry residues, pulp and paper waste streams, and municipal solid waste, are abundant and underutilized resources, which can be converted to ethanol.

The production of ethanol from biomass requires the following basic steps: pretreatment to hydrolyze the hemicellulose, hydrolysis of cellulose to produce glucose, fermentation of sugars to ethanol, and ethanol recovery. There are different process configurations, both enzyme based and nonenzyme based, that can be used to achieve the overall goal. In the nonenzyme based approach, acid is used for both hemicellulose and cellulose hydrolysis, and the mode is separate hydrolysis and fermentation (SHF); both six-carbon (hexoses, i.e., glucose, mannose, and galactose) and five-carbon sugars (pentoses, i.e., xylose and arabinose) are fermented to ethanol. In the enzymatic approach, dilute-acid pretreatment is used to hydrolyze the hemicellulose portion. The saccharification (hydrolysis) of cellulose to cellobiose and eventually to glucose is catalyzed by the synergistic action of cellulase and $\beta$-glucosidase enzymes. The mode of operation used is simultaneous saccharification and cofermentation (SSCF); cofermentation refers to the fermentation of both six-carbon and five-carbon sugars to ethanol. In this study the following two specific biomass-to-ethanol conversion technologies are used:

- Enzyme-based process

- Two-stage dilute-acid process

The flow diagrams for the two technology options are shown in Figure 6 and Figure 7, and process descriptions follow. It is assumed that no corn steep liquor (CSL) is used in fermentations because CSL is not relevant to a plant in India. (CSL is used in the processes described by Kadam et al. 1999.) Instead, an equivalent amount of ammonia, based on nitrogen content, is used; no other nutrients or micronutrients are added (or if necessary, are assumed to be available in the hydrolysis milieu). 


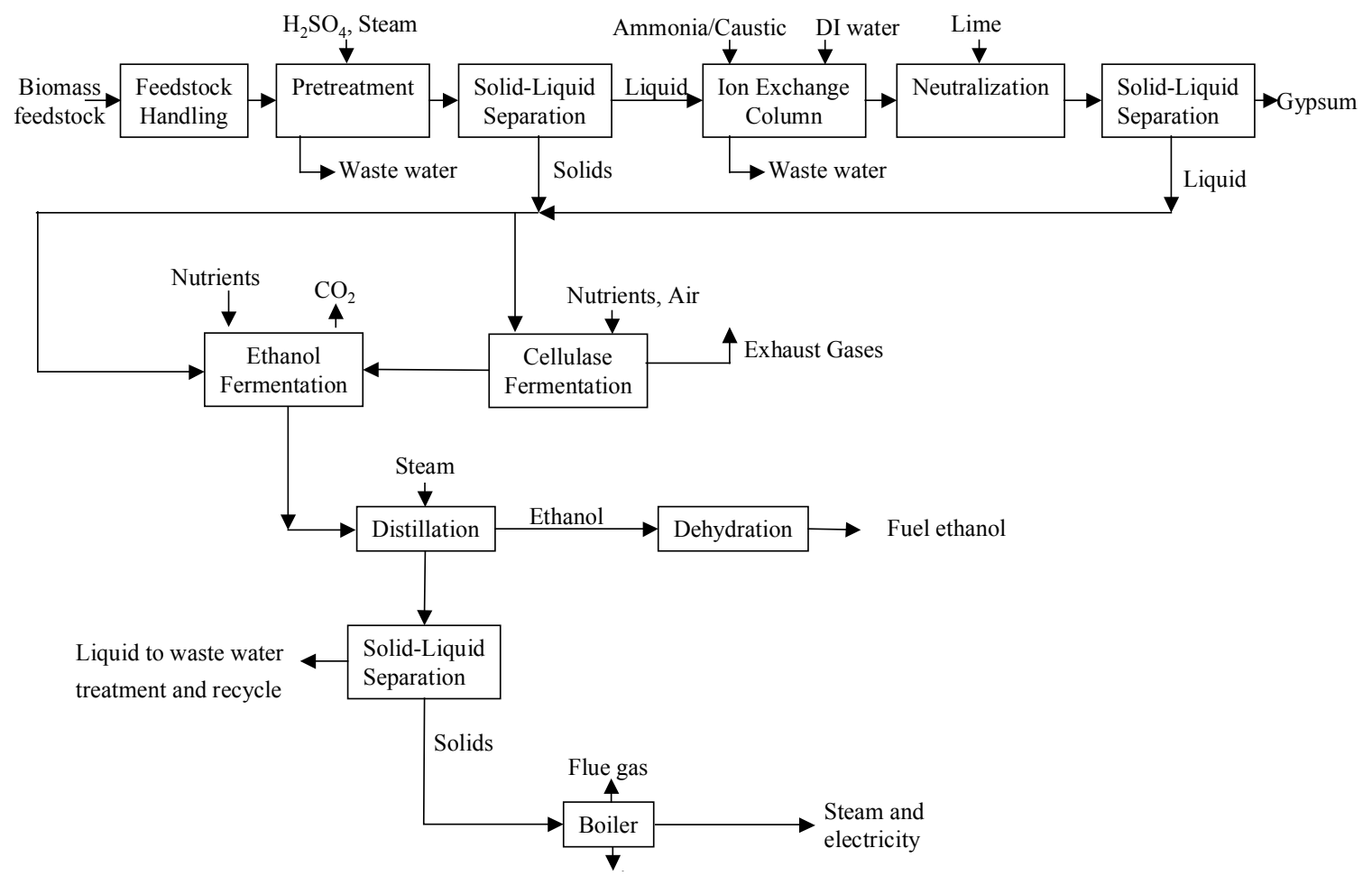

Figure 6. Enzymatic process flow diagram.

\subsubsection{Enzymatic Process}

A generalized process was modeled based on Trichoderma reesei-derived cellulases for cellulose hydrolysis and an appropriate recombinant ethanologen for cofermentation of six-carbon and five-carbon sugars to ethanol. The enzyme-based process, which is a relatively long-term option, consists of four basic unit operations:

1) Pretreatment

2) Cellulase production

3) Ethanol production

4) Product purification

\subsubsection{Feedstock Preparation and Pretreatment}

The biomass is milled to an average size of $15 \mathrm{~mm}$. A screw feeder conveys the biomass from the storage bunker to the acid impregnator. Dilute sulfuric acid and low-pressure steam are also fed to the acid impregnator. The acidic slurry is discharged from the acid impregnator into the pretreatment reactor. High-pressure steam and additional dilute sulfuric acid are fed to the reactor where hemicellulosic sugars are hydrolyzed to their respective monomers and/or oligomers (temperature ranges from $160^{\circ}-180^{\circ} \mathrm{C}$, liquid phase acid concentration ranges from $0.7 \%-1.0 \%$ wt.). 
The hydrolyzed mash is discharged from the acid hydrolysis reactor into a lower-pressure flash drum where cooling quenches the reactions. The hydrolyzate is separated from the solids in a solid-liquid separation step. The hydrolyzate is then pumped to the neutralization and detoxification tank using continuous ion exchange that employs a weak-base anion resin. The process primarily removes acetic acid and other organic species that could be toxic to the microorganisms used during fermentation.

Lime is used to neutralize the detoxified hydrolyzate; the neutralization reaction produces calcium sulfate, which is removed in a solid-liquid separation step. The neutralized hydrolyzate is pumped through a heat exchanger where, using cooling tower water, it is cooled to fermentation temperature. The hydrolyzate and solids from the solid-liquid separation step are then pumped to the ethanol fermentation section.

\subsubsection{Cellulase Production}

Cellulase production is by $T$. reesei using a slipstream of pretreated biomass as a carbon source. The fermentation is conducted in fed-batch mode at $28^{\circ} \mathrm{C}$ and $\mathrm{pH} 5$. For a low-cost product such as ethanol, the enzyme need not be processed to any great extent to be useful. Whole broth from cellulase fermentation is actually more effective for the SSCF process. In this process, the whole fermentation broth is used as a source of cellulase enzyme. Because enzyme production is via the fed-batch mode and the SSCF is a continuous process, a surge storage tank is necessary. It is assumed that cellulase production using pretreated bagasse as substrate is feasible.

\subsubsection{Fermentation}

The SSCF process using cellulase enzymes and a recombinant Zymomonas mobilis converts cellulose and five-carbon sugars to ethanol and $\mathrm{CO}_{2}$. Cellulase catalyzes the hydrolysis of cellulose to glucose. A recombinant xylose-fermenting yeast, recombinant E. coli and Klebsiella oxytoca are also possible choices.

The SSCF operation takes place in continuous anaerobic fermenters. Gravity drives the flow of fermentation broth between fermenters. Fermentation exhaust gases consisting of carbon dioxide and ethanol vapor are sent to the vent scrubber for ethanol recovery. The SSCF broth is pumped to the distillation section.

\subsubsection{Distillation and Ethanol Dehydration}

Ethanol is separated from the fermentation beer by conventional distillation technology and is dehydrated using molecular sieve technology. The still bottoms are collected and the $99.7 \%$ ethanol is sent to fuel storage. The lignin residue is further dewatered in a solid-liquid separation step. The liquid stream is sent to wastewater treatment and the recycle loop.

\subsubsection{Ligneous Residue}

The dewatered ligneous residue is burned on-site to cogenerate steam and electricity that can be used by the process. Excess electricity is generated, which can be sold to the grid. 


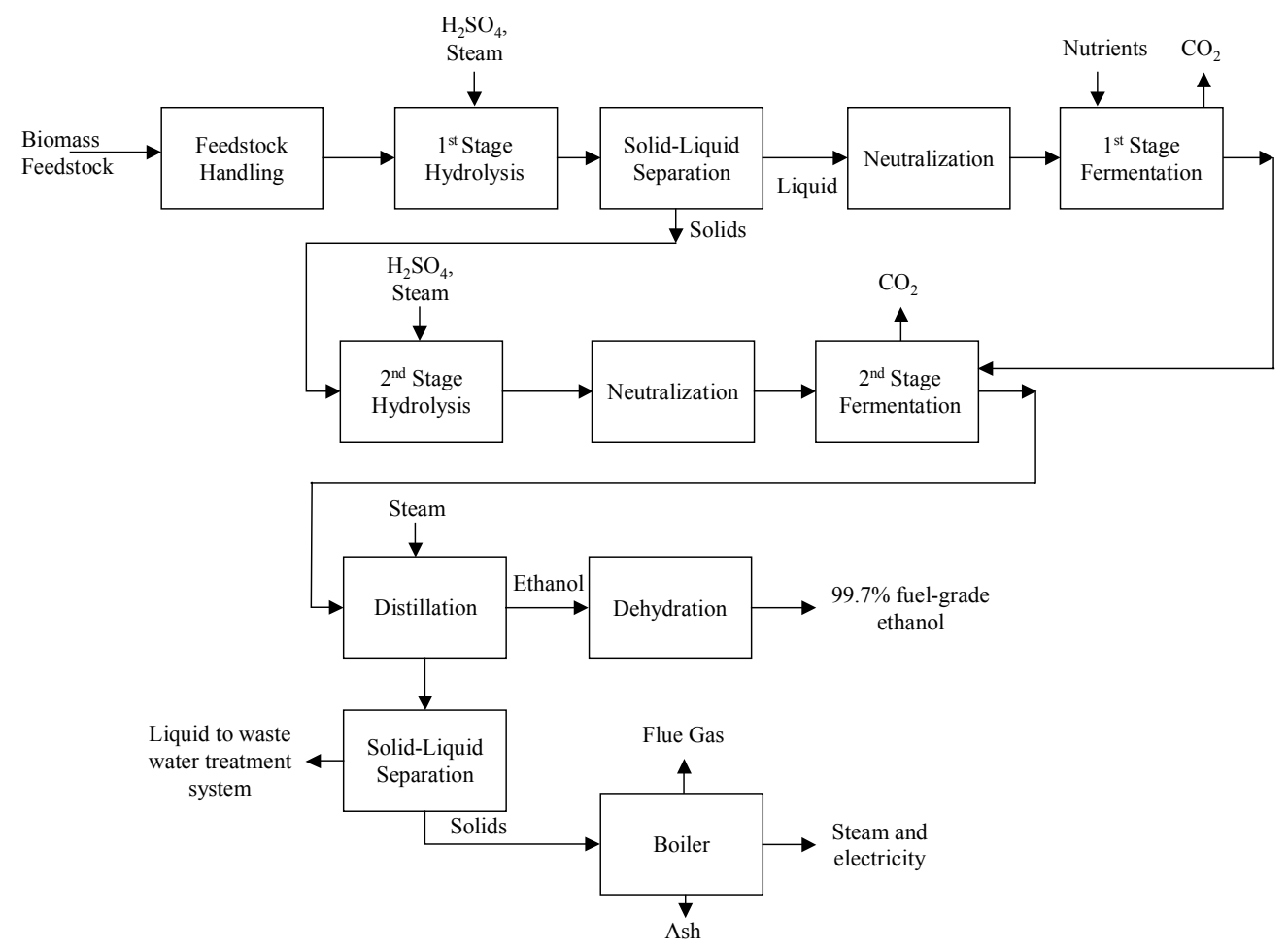

Figure 7: Two-stage dilute-acid process flow diagram.

\subsubsection{Two-Stage Dilute Acid Process}

The two-stage dilute acid process, which is a short-term option appropriate for a plant in India, consists of four basic unit operations:

1) First stage hydrolysis

2) Second stage hydrolysis

3) Ethanol fermentation

4) Product purification

\subsubsection{First-Stage Hydrolysis}

Prior to acid hydrolysis, the biomass is milled to an average size of $15 \mathrm{~mm}$. The feedstock is then mixed with dilute sulfuric acid at a concentration of $0.70 \%$ and soaked at $50^{\circ} \mathrm{C}$ for 3 hours. In the first hydrolysis, the acid-impregnated biomass is heated to $180^{\circ}-185^{\circ} \mathrm{C}$ for $3-5$ minutes in a digester (hydrolyzer) to hydrolyze the hemicellulose; some cellulose hydrolysis also takes place in this step. The resulting slurry is pressed to obtain a liquid stream, which is sent to neutralization. Residual acid in the sugar stream is neutralized by adding lime, which forms a gypsum precipitate. Gypsum is removed in a solid-liquid separation step. The liquid stream is sent to first-stage fermentation. 


\subsubsection{Second-Stage Hydrolysis}

The solids remaining after the first hydrolysis and solid-liquid separation are again acidimpregnated at the same conditions. In the second hydrolysis step, acid-impregnated material is heated for $3-5$ minutes at $200^{\circ}-210^{\circ} \mathrm{C}$ to effect further cellulose hydrolysis. The resulting slurry is neutralized by adding lime. This stream is sent to second-stage fermentation without separating out the gypsum.

\subsubsection{Fermentation}

A recombinant $Z$. mobilis is used to ferment both six-carbon and five-carbon sugars to ethanol and $\mathrm{CO}_{2}$. (A recombinant xylose-fermenting yeast, rDNA E. coli or K. oxytoca can also be used.) First- and second-stage fermentations are carried out in continuous, anaerobic fermenters. The flow of fermentation broth between fermenters is facilitated by gravity. Fermentation off gases, containing mostly $\mathrm{CO}_{2}$ and ethanol vapor, are sent to the vent scrubber for ethanol recovery. The fermentation broth is sent to the distillation section.

\subsubsection{Distillation and Ethanol Dehydration}

Ethanol is separated from the fermentation beer by conventional distillation technology and is dehydrated with molecular sieve technology. The $99.7 \%$ ethanol is sent to fuel storage. The lignin residue is further dewatered in a solid-liquid separation step. The liquid stream is sent to wastewater treatment and the recycle loop.

\subsubsection{Ligneous Residue}

The dewatered ligneous residue, containing mostly lignin and cellulose, is burned on-site to cogenerate steam and electricity that can be used by the process. The net electricity produced is sold to the grid.

\subsubsection{Data Summary for Bagasse-to-Ethanol Processes}

The estimates of inputs and outputs for the two processes were developed using NREL's Aspen ${ }^{\circledR}$-based (Aspen Technology, Inc., Cambridge, MA) models, with technology targets established for the middle of the decade (Wooley et al. 1999). These estimates, using $1 \mathrm{~kg}$ of dry bagasse or $1 \mathrm{~L}$ of ethanol as the basis, are reported in Table 14. Combustion-related properties of green feedstock and ligneous residues are listed in Table 15. These are useful in calculating energy, $\mathrm{CO}_{2}$, and ash generation.

\subsection{Sulfuric Acid Production}

The production of sulfuric acid $\left(\mathrm{H}_{2} \mathrm{SO}_{4}\right)$ was modeled based on the contact process according to the following reactions:

$$
\begin{array}{lll}
2 \mathrm{SO}_{2}+\mathrm{O}_{2} & \rightarrow & 2 \mathrm{SO}_{3} \\
\mathrm{SO}_{3}+\mathrm{H}_{2} \mathrm{O} & \rightarrow & \mathrm{H}_{2} \mathrm{SO}_{4}
\end{array}
$$

Emissions information is based on data collected from a number of production plants worldwide, as well as engineering calculations. 
Table 14. Data summary for bagasse-to-ethanol processes

\begin{tabular}{|c|c|c|c|c|}
\hline \multirow{2}{*}{$\begin{array}{c}\text { Environmental } \\
\text { Flows }\end{array}$} & \multicolumn{2}{|c|}{ Enzymatic Process } & \multicolumn{2}{|c|}{ Two-Stage Dilute Acid Process } \\
\hline & (kg/kg bagasse) & (kg/L ethanol) & (kg/kg bagasse) & (kg/L ethanol) \\
\hline Biomass & 1.000 & 3.318 & 1.000 & 4.242 \\
\hline Lime & 0.009 & 0.030 & 0.013 & 0.057 \\
\hline Water & 1.966 & 6.525 & 3.591 & 15.232 \\
\hline $\mathrm{NH}_{3}$ & 0.028 & 0.093 & 0.025 & 0.106 \\
\hline Diesel & 0.005 & 0.017 & 0.004 & 0.019 \\
\hline $\mathrm{H}_{2} \mathrm{SO}_{4}$ & 0.044 & 0.146 & 0.048 & 0.202 \\
\hline Outputs & (kg/kg bagasse) & (kg/L ethanol) & (kg/kg bagasse) & $(\mathrm{kg} / \mathrm{L}$ ethanol) \\
\hline Ethanol & 0.238 & 0.789 & 0.186 & 0.789 \\
\hline Gypsum & 0.025 & 0.083 & 0.031 & 0.132 \\
\hline Ash & 0.040 & 0.132 & 0.077 & 0.328 \\
\hline Ligneous residue & 0.444 & 1.472 & 0.600 & 2.542 \\
\hline Biogas methane & 0.015 & 0.051 & 0.016 & 0.070 \\
\hline Total $\mathrm{CO}_{2}$ & 1.170 & 3.883 & 1.307 & 5.545 \\
\hline & (MJ/kg biomass) & $(\mathrm{MJ} / \mathrm{L}$ ethanol) & (MJ/kg biomass) & $(\mathrm{MJ} / \mathrm{L}$ ethanol) \\
\hline Net electricity & 0.859 & 2.849 & 1.146 & 4.863 \\
\hline
\end{tabular}

Table 15. Combustion-related properties of green feedstock and ligneous residues

\begin{tabular}{lccc}
\hline & $\begin{array}{c}\text { Green } \\
\text { Feedstock }\end{array}$ & $\begin{array}{c}\text { Enzyme } \\
\text { Process Fuel } \\
\text { Residue }\end{array}$ & $\begin{array}{c}\text { Acid Process } \\
\text { Fuel Residue }\end{array}$ \\
\hline Average heating value, MJ/kg & 19.29 & 21.54 & 19.22 \\
Carbon content, dry wt \% & 48.76 & 57.91 & 52.74 \\
Ash content, dry wt \% & 3.70 & 8.21 & 11.63 \\
\hline
\end{tabular}

\subsection{Ammonia Production}

Synthetic anhydrous ammonia production was modeled based on the natural gas-reforming process. Natural gas is used both as feedstock and fuel in this process at the following levels:

- $60 \%$ feedstock (the feedstock value of the ammonia $=23.61 \mathrm{MJ}$ )

- $40 \%$ fuel

The process modeled assumes no $\mathrm{CO}_{2}$ recovery. 


\subsection{Lime Production}

The process model for lime production includes: limestone extraction, limestone crushing, and limestone calcination. The production of lime was modeled according to the following reactions:

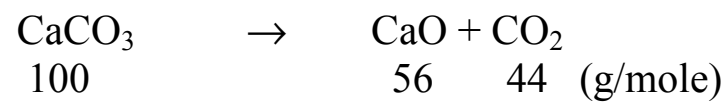

Transport of limestone to a user facility is not taken into account because its impact is negligible.

\subsection{Electricity Production}

The electricity grid model includes the following:

- Precombustion processes: coal mining (surface and underground) and transportation, natural gas extraction and transportation, crude oil extraction (off-shore and on-shore) refining, and transportation, production of nuclear fuel ( $\mathrm{UF}_{6}$ accumulation and fuel rod manufacturing), and hydroelectric power production

- Combustion in power plants

- Distribution (losses: 7.7\%)

An average situation for India modeled by Ecobalance Inc. was used.

\subsection{Steam Production}

The energy necessary to convert water to steam is based on the enthalpy of the steam $(2.6 \mathrm{MJ} / \mathrm{kg}$ at approximately $150 \mathrm{psi}$ and $350^{\circ} \mathrm{F}$ ) and a boiler efficiency of $80 \%$. Steam is assumed to be produced by combusting fuel in industrial boilers. The fuel can consist of coal, natural gas, heavy fuel oil, or ligneous residue (from ethanol fermentation). The heating values for ligneous residues are given Table 15; those for the other fuels are as follows:

- Natural Gas - $52 \mathrm{MJ} / \mathrm{kg}$

- Heavy Fuel Oil - $42 \mathrm{MJ} / \mathrm{kg}$

- Coal $-29.3 \mathrm{MJ} / \mathrm{kg}$

The emission factors for industrial boilers were obtained from the AP-42 report by the EPA (EPA 1995b). These numbers were compared with a study done by the Argonne National Laboratory (Wang 1996), to verify and expand on the EPA emission factors.

All the factors reported are for uncontrolled emissions. If control technologies are used, the emission factors should be reduced by the efficiencies of the control devices. Emission factors for heavy fuel oil and natural gas production are outlined by Kadam et al. (1999). 


\subsection{Gasoline System}

This system includes precombustion data for gasoline. The precombustion steps include extraction of crude oil from the ground, transportation of the crude oil to a refinery, and refining the crude oil into finished refinery products. Transportation of the finished refinery products to the point of use is also included at this stage.

\subsection{Gasoline and E10 Fuel Combustion}

The modeling of gasoline combustion is based on emissions from E10 (oxygenated gasoline) and current gasoline.

\subsubsection{Tailpipe Emissions}

Toxic air pollutants can be emitted from motor vehicle systems by two emission-producing processes: combustion products from the exhaust system and evaporation from the fuel storage and delivery system. An overall emissions profile from the exhaust system and evaporation is given in Table 16 for the current gasoline and E10 blend. Overall emissions for the current leaded gasoline are from Ecobalance Inc.'s database for European leaded gasoline, and those for the E10 blend were estimated by incorporating the change in emissions discussed in Table 17 for low-level ethanol blends, such as E10 (CRFA 1999). For example, a 20\% reduction in CO (lower than that in Table 16) for the E10 blend yields $158 \mathrm{~g} \mathrm{CO}$ per $\mathrm{kg}$ fuel (198 x 0.8). Components specific only to gasoline combustion, e.g., benzene were reduced by $10 \%$ for the E10 blend. Although some data are available for emissions of ethanol blends (Harvey and Adler 1988; Taylor et al. 1996; CARB 1998), these are for very specific cases, and the estimates generated in Table 16 were considered to be generally more applicable.

Table 16. Overall emissions for current gasoline and E10 blend

\begin{tabular}{lcc}
\hline & Current Gasoline, $\mathbf{g} / \mathbf{k g}$ & E10 Blend, $\mathbf{g} / \mathbf{k g}$ \\
\hline Benzene & 1.53 & 1.37 \\
Benzo(a)pyrene & $5 \times 10^{-5}$ & $4.5 \times 10^{-5}$ \\
Carbon dioxide & 2775 & 2784 \\
& & $(2583.6$ fossil + \\
Carbon monoxide & & 200.8 biomass $)$ \\
Ethanol & 198 & 158 \\
Hydrocarbons (except methane) & 0 & 0.38 \\
Lead & 38 & 37.5 \\
Methane & 0.2 & 0.18 \\
Nitrogen oxides $\left(\mathrm{NO}_{\mathbf{x}}\right.$ as $\left.\mathrm{NO}_{2}\right)$ & 1.5 & 1.34 \\
Nitrous oxide $\left(\mathrm{N}_{2} \mathrm{O}\right)$ & 31 & 32.6 \\
Sulfur oxides $\left(\mathrm{SO}_{\mathrm{x}}\right.$ as $\left.\mathrm{SO}_{2}\right)$ & 0.13 & 0.13 \\
& 0.26 & 0.23 \\
\hline
\end{tabular}


Table 17. Overview of change in emissions from low-level and high-level ethanol blends

\begin{tabular}{|c|c|c|}
\hline Emission & $\begin{array}{l}\text { Low-Level Blends } \\
\text { (e.g., E10) }\end{array}$ & $\begin{array}{l}\text { High-Level Blends } \\
\text { (e.g., E85) }\end{array}$ \\
\hline Carbon monoxide (CO) & $25-30 \%$ decrease & $25-30 \%$ decrease \\
\hline Carbon dioxide $\left(\mathrm{CO}_{2}\right)$ & $10 \%$ decrease & $\begin{array}{l}\text { Up to } 100 \% \text { decrease } \\
\text { (E100) }\end{array}$ \\
\hline Nitrogen oxides $\left(\mathrm{NO}_{\mathrm{x}}\right)$ & $5 \%$ increase or decrease & Up to $20 \%$ decrease \\
\hline \multicolumn{3}{|l|}{ Volatile organic compounds (VOCs) } \\
\hline Exhaust & $7 \%$ decrease & $30 \%$ or more decrease \\
\hline Evaporative & No change (in Canada) & Decrease \\
\hline $\begin{array}{l}\text { Sulfur dioxide }\left(\mathrm{SO}_{2}\right) \text { and Particulate } \\
\text { matter }\end{array}$ & Decrease & Significant decrease \\
\hline Aldehydes & $\begin{array}{l}30-50 \% \text { increase (but } \\
\text { negligible due to catalytic } \\
\text { converter) }\end{array}$ & Insufficient data \\
\hline Aromatics (benzene and butadiene) & Decrease & More than $50 \%$ decrease \\
\hline
\end{tabular}

Unlike in the United States, where ethanol blends have a regulatory waiver (in most parts of the country) and are allowed to have increased volatility, Canadian regulations require that the volatility of ethanol blends must match that of standard gasoline (CRFA 1999). Hence, the evaporative emissions of VOCs from ethanol blends in Canada are approximately equal to those from conventional gasoline. It is assumed that the Canadian regulatory model is followed in India.

Because the environmental burdens are calculated on a differential basis, i.e., $1 \mathrm{~kg}$ ethanol in Scenario 2 versus $0.633 \mathrm{~kg}$ gasoline in Scenario 1, combustion emissions of Scenario 2 were modified as discussed here. Emissions that were solely from gasoline were omitted from those for ethanol. Those that were common emissions were apportioned to gasoline and ethanol-based on their carbon contribution to the blend. Ethanol's contribution to these emissions was then $6.4 \%$ of the total blend. This was then expressed based on a unit $\mathrm{kg}$ of ethanol (Table 18). This approach was considered to be better for a fair comparison of the two scenarios.

\subsubsection{Biomass versus Fossil Fuel $\mathrm{CO}_{2}$}

A portion of the $\mathrm{CO}_{2}$ that is generated from the combustion of the oxygenated fuel containing ethanol comes from biomass. The amount of biomass-derived $\mathrm{CO}_{2}$ was calculated based on the carbon content of ethanol. $\mathrm{CO}_{2}$ sequestered in the biomass is carried through the LCA as $\mathrm{CO}_{2}$ (biomass) versus $\mathrm{CO}_{2}$ (fossil), which results from the combustion of petroleum resources. Biomass and fossil $\mathrm{CO}_{2}$ were treated individually in the LCA model and reported separately in the results. 
Table 18. Apportioned emissions for E10 Blend

\begin{tabular}{lrrrrr}
\hline & $\begin{array}{c}\text { Current } \\
\text { Gasoline, } \\
\text { g/kg }\end{array}$ & $\begin{array}{c}\text { E10 Blend, } \\
\text { g/kg }\end{array}$ & & $\begin{array}{c}\text { Apportioned Emissions } \\
\text { E10 Blend, g/kg blend }\end{array}$ & $\begin{array}{c}\text { Ethanol } \\
\text { contribution, } \\
\text { g/kg ethanol }\end{array}$ \\
\cline { 5 - 6 } & 1.53 & 1.37 & 1.37 & 0.00 & 0.00 \\
Benzene & $5.00 \mathrm{E}-$ & $4.50 \mathrm{E}-$ & $4.50 \mathrm{E}-05$ & 0.00 & 0.00 \\
Benzo(a)pyrene & 05 & 05 & & & \\
& 0 & 200.2 & 0.00 & 200.2 & 1913.0 \\
Carbon dioxide, biomass & 2775 & 2584 & 2584.0 & 0.00 & 0.00 \\
Carbon dioxide, fossil & 198 & 158 & 148.0 & 10.03 & 95.9 \\
Carbon monoxide & 0 & 0.38 & 0.00 & 0.38 & 3.63 \\
Ethanol & 38 & 37.5 & 35.12 & 2.38 & 22.8 \\
Hydrocarbons (except $\left.\mathrm{CH}_{4}\right)$ & 0.2 & 0.18 & 0.18 & 0.00 & 0.00 \\
Lead & 1.5 & 1.34 & 1.25 & 0.09 & 0.81 \\
Methane & 31 & 32.6 & 30.53 & 2.07 & 19.8 \\
Nitrogen oxides $\left(\mathrm{NO}_{\mathrm{x}}\right.$ as & & & & & \\
$\quad$ NO & & & & & \\
Nitrous oxide $\left(\mathrm{N}_{2} \mathrm{O}\right)$ & 0.13 & 0.13 & 0.12 & 0.01 & 0.08 \\
Sulfur oxides $\left(\mathrm{SO}_{\mathrm{x}}\right.$ as $\left.\mathrm{SO}_{2}\right)$ & 0.26 & 0.23 & 0.23 & 0.00 & 0.00 \\
\hline
\end{tabular}

The net biomass $\mathrm{CO}_{2}$ produced by the system is assumed to be zero. The positive values for biomass $\mathrm{CO}_{2}$ reported in the results are assumed to be offset by biomass $\mathrm{CO}_{2}$ uptake by the biomass during its growth. Plants use solar energy to fix carbon from carbon dioxide during photosynthesis. For this study, it is assumed that $\mathrm{CO}_{2}$ uptake by the sugarcane plant will be released back to the environment through open-field burning of bagasse or through the burning of ethanol and lignin residue emanating from bagasse. Thus, the net $\mathrm{CO}_{2}$ balance for growing and disposal of biomass is zero. Therefore, biomass-derived $\mathrm{CO}_{2}$ is not used in the impact assessment phase to calculate greenhouse gas potential.

\section{Data Quality AND Sources}

For an LCA, there are two different types of data: primary and secondary [SETAC 1993b]. Primary data are obtained directly from individual production plants or companies. Secondary data are published sources such as databases, industry or government publications, journals, or books. Another kind of secondary data also include "educated guesses" or data coming from experts based on their knowledge in the field, but not published.

In general, the goals for data collection, quality, and utilization are to use the most recent data available that are representative of an industry or practice. The goals specifically for this study were to obtain data on the processes leading to the disposal of biomass, the conversion of biomass into ethanol, and the use of E10 and current gasoline.

\subsection{Data Sources}

As it is difficult to obtain data specific for the Indian scenario, and given the limited scope and budget of this project, most of the data used is of U.S. or European origin (see Table 19). 
However, this should not detract from the results because they can be viewed as a first approximation of what benefits can be achieved in India.

Table 19. Data sources and quality

\begin{tabular}{|c|c|c|c|c|}
\hline $\begin{array}{c}\text { Data } \\
\text { Category }\end{array}$ & Description & $\begin{array}{l}\text { Source Type } \\
\text { and Date }\end{array}$ & $\begin{array}{c}\text { Geographic } \\
\text { and Temporal } \\
\text { Representation }\end{array}$ & Reliability and Completeness \\
\hline $\begin{array}{l}\text { Biomass } \\
\text { burning }\end{array}$ & $\begin{array}{l}\text { Materials, } \\
\text { emissions }\end{array}$ & $\begin{array}{l}\text { Secondary/pri } \\
\text { mary; } \\
\text { EPA AP-42, } \\
\text { CARB (1997) }\end{array}$ & $\begin{array}{l}\text { United States } \\
1990 \mathrm{~s}\end{array}$ & $\begin{array}{l}\text { Reliable but incomplete } \\
\text { because the emissions do not } \\
\text { take into account the effect } \\
\text { of burning conditions }\end{array}$ \\
\hline $\begin{array}{l}\text { Ethanol } \\
\text { production }\end{array}$ & $\begin{array}{l}\text { Materials, } \\
\text { energy, } \\
\text { emissions }\end{array}$ & $\begin{array}{l}\text { Primary; } \\
\text { NREL (1999) }\end{array}$ & $\begin{array}{l}\text { United States } \\
1990 \mathrm{~s}\end{array}$ & $\begin{array}{l}\text { Reliable and complete (based } \\
\text { on bench-scale data and } \\
\text { process modeling) }\end{array}$ \\
\hline $\begin{array}{l}\text { Electricity } \\
\text { production }\end{array}$ & $\begin{array}{l}\text { Materials, } \\
\text { energy, } \\
\text { emissions }\end{array}$ & Secondary & $\begin{array}{l}\text { India } \\
1990 \mathrm{~s}\end{array}$ & Reliable and complete \\
\hline $\begin{array}{l}\text { Steam } \\
\text { production }\end{array}$ & $\begin{array}{l}\text { Materials, } \\
\text { energy, } \\
\text { emissions }\end{array}$ & $\begin{array}{l}\text { Secondary; } \\
\text { EPA AP-42 } \\
(1997)\end{array}$ & $\begin{array}{l}\text { United States } \\
1980 \mathrm{~s}, 1990 \mathrm{~s}\end{array}$ & Reliable and complete \\
\hline $\begin{array}{l}\text { Gasoline } \\
\text { production } \\
\text { and use }\end{array}$ & $\begin{array}{l}\text { Materials, } \\
\text { energy, } \\
\text { emissions }\end{array}$ & $\begin{array}{l}\text { Secondary; } \\
\text { see references } \\
\text { in Kadam et al. } \\
(1999)\end{array}$ & $\begin{array}{l}\text { Europe, World } \\
1980 \mathrm{~s}, 1990 \mathrm{~s}\end{array}$ & Reliable and complete \\
\hline E10 use & $\begin{array}{l}\text { Materials, } \\
\text { emissions }\end{array}$ & $\begin{array}{l}\text { Secondary; } \\
\text { EPA AP-42 } \\
(1997), \text { CRF } \\
\text { (1999) }\end{array}$ & $\begin{array}{l}\text { United States } \\
1990 \mathrm{~s}\end{array}$ & Reliable and complete \\
\hline
\end{tabular}

\subsection{Data Quality}

Data in an LCA should have indicators for reliability and completeness. The reliability indicator pertains to how data were obtained and verified, independent of the data quality goals outlined in the study. The completeness indicator pertains to how representative the data samples are, i.e., do the data represent an adequate sample size, and do the data cover an adequate period such that normal fluctuations are evened out? The completeness indicator is also treated as independent of the data quality goals outlined in the study. Currently, actual data indicators have not been established in LCA guidelines. Instead, a table is generally provided to indicate the type of data in each life cycle sector and the reliability and completeness for each. Table 19 provides the general data categories in this study and provides a description of each, the sources and whether they are primary or secondary, a "checklist" of the reliability criteria, including the geographical and temporal extent of the data, and limitations. 


\section{Results ANd Discussion}

\subsection{Presentation of Results}

The results are presented here for the two different scenarios: burning versus diverting bagasse to ethanol. For each scenario, two methods of ethanol production are evaluated: dilute acid process and enzyme process. As mentioned earlier, the basis chosen for the comparison of the two different biomass disposal options is 1 dry $t$ of bagasse.

\subsection{Explanation of Negative Flows}

There are some negative values in the summary tables and in the figures, which arise from the electricity offset of the ethanol scenario. Besides actual flows, percentage differences are also included, which indicate the degree to which the values for the ethanol scenario (Scenario 2) were different from those for the burning scenario (Scenario 1), i.e.,

$$
\% \text { Difference }=\frac{\text { Scenario } 1 \text { value }- \text { Scenario } 2 \text { value }}{\text { Scenario } 1 \text { value }} \times 100
$$

A positive value indicates the percentage by which the values for the ethanol scenario were lower than those for the burning scenario, and vice versa.

\subsection{Hydrocarbon Emission}

As individual speciated emissions data are not available for all modules, all speciated nonmethane hydrocarbon flows have been aggregated to give a value for the net hydrocarbon emissions. These include volatile organic compounds (VOCs), ethanol (air emissions), furfural, hydroxymethyl furfural (HMF), aldehydes, benzene, and hydrocarbons (except methane).

\subsection{Time-Space Implications of Emissions}

It should be noted that this report shows the life-cycle emissions of the two options without considering the spatial and temporal attributes, meaning that the results are aggregated over different locations and different time frames. Therefore, it does not take into account the fact that open burning results in a pulse of emissions at one time and location versus ethanol combustion in a vehicle that takes place over a period of time and at different locations. This report only shows the difference in the total emissions of the two options and does not account for concentrations of pollutants at a given time.

\subsection{Life Cycle Energy Balance}

The energy use of the competing scenarios is one measure of their overall environmental performance. LCIs provide an opportunity to quantify both the total energy demands and the overall energy efficiencies of processes and products. In this study, several different types of energy flows are tracked through each life cycle. For clarity, each of these energy flows is defined below. 
Table 20. Explanation of negative flows

\begin{tabular}{|c|c|c|c|}
\hline & Flow & $\begin{array}{l}\text { Negative Value in the } \\
\text { Totals for Each Option }\end{array}$ & $\begin{array}{c}\text { Negative Value in the \% } \\
\text { Difference Column }\end{array}$ \\
\hline Inflows & $\begin{array}{l}\text { All raw material } \\
\text { inflows }\end{array}$ & $\begin{array}{l}\text { Indicates an offset that is } \\
\text { greater than the use of } \\
\text { materials for the option. } \\
\text { Primarily due to electricity } \\
\text { offset of energy-related } \\
\text { materials. }\end{array}$ & $\begin{array}{l}\text { Indicates that the ethanol } \\
\text { option has higher raw material } \\
\text { inflows than the burning } \\
\text { option. } \\
\text { (Unfavorable to ethanol } \\
\text { scenario) }\end{array}$ \\
\hline Outflows & $\begin{array}{l}\text { All air emissions, } \\
\text { water effluents, and } \\
\text { solid waste }\end{array}$ & $\begin{array}{l}\text { Indicates that electricity } \\
\text { offset is greater than the } \\
\text { emission of the pollutant for } \\
\text { the option resulting in a net } \\
\text { negative value. }\end{array}$ & $\begin{array}{l}\text { Indicates that the ethanol } \\
\text { option has higher emissions } \\
\text { than the burning option. } \\
\text { (Unfavorable to ethanol } \\
\text { scenario) }\end{array}$ \\
\hline \multirow[t]{3}{*}{ Energy } & Nonrenewable energy & $\begin{array}{l}\text { Indicates that electricity } \\
\text { offset is greater than the } \\
\text { energy use of the option } \\
\text { resulting in a net negative } \\
\text { value. }\end{array}$ & $\begin{array}{l}\text { Indicates that the ethanol } \\
\text { option has higher } \\
\text { nonrenewable energy use than } \\
\text { the burning option. } \\
\text { (Unfavorable to ethanol } \\
\text { scenario) }\end{array}$ \\
\hline & Renewable energy & & $\begin{array}{l}\text { Indicates that the ethanol } \\
\text { option has higher renewable } \\
\text { energy use than the burning } \\
\text { option. } \\
\text { (Favorable to ethanol } \\
\text { scenario) }\end{array}$ \\
\hline & Total primary energy & & $\begin{array}{l}\text { Indicates that the ethanol } \\
\text { option has higher total energy } \\
\text { use than the burning option. } \\
\text { (Unfavorable to ethanol } \\
\text { scenario) }\end{array}$ \\
\hline
\end{tabular}

- Total Primary Energy. All raw materials extracted from the environment can contain ${ }^{2}$ energy. In estimating the total primary energy inputs to each life cycle, the cumulative energy content of all resources extracted from the environment is considered.

\footnotetext{
${ }^{2}$ The energy "contained" in a raw material is the amount of energy that would be released by the complete combustion of that raw material. This "heat of combustion" can be measured in two different ways: as a higher heating value or a lower heating value. Combustion results in the formation of $\mathrm{CO}_{2}$ and water. Higher heating values consider the amount of energy released when the final combustion products are gaseous carbon dioxide and liquid water. Lower heating values take into account the loss of energy associated with the vaporization of the liquid water combustion product. The energy content used is based on the lower heating values for each material.
} 
- Feedstock Energy. Energy contained in raw materials that end up directly in the final product is termed "feedstock energy." For ethanol production, feedstock energy includes the energy contained in the biomass. Feedstock energy is a subset of the primary energy inputs.

- Process Energy. The second major subset of primary energy is "process energy." This is limited to energy inputs in the life cycle exclusive of the energy contained in the feedstock (as defined in the previous bullet). It is the energy contained in raw materials extracted from the environment that does not contribute to the energy of the product itself, but is needed in the processing of feedstock energy into its final product form. Process energy is primarily from coal, natural gas, uranium, and hydroelectric power consumed directly or indirectly in the product life cycle.

- Fossil or Nonrenewable Energy. The primary energy that comes from fossil sources specifically (coal, oil, and natural gas) is tracked because it is important to distinguish between fossil and non-fossil energy. All three of the previously defined energy flows can be categorized as fossil or nonfossil energy.

- Renewable Energy. Renewable energy refers to energy obtained from biomass sources and also to electricity production from renewable sources such as biomass and hydroelectricity.

In the summary tables, the following energy values are reported: 1) process energy, 2) fossil or nonrenewable energy, 3) renewable energy, and 4) total primary energy. Criteria air pollutants are linked to the use of both nonrenewable and renewable energy, whereas natural resource depletion $^{3}$ and fossil $\mathrm{CO}_{2}$ emissions are only linked to nonrenewable sources. Renewable energy use in Scenario 1 refers to renewable resources used to produce a portion of electricity used. Process energy indicates the net energy input to the process and can be useful in comparing process options.

\subsection{LCI for Burning versus Diverting Bagasse to Ethanol: Enzyme Process}

For the enzyme process, Scenario 2 leads to a decrease from Scenario 1 for almost all of the key environmental flows (Table 21). The various environmental flows and their implications of these are discussed below. Natural gas consumption and CODs for key modules are given in Table 22; this allows explanation of higher values for these environmental flows in Scenario 2.

\footnotetext{
${ }^{3}$ Soil erosion is not included in the calculation of natural resource depletion because data were not available. The effects of biomass harvesting on soil erosion is more difficult to quantify than the removal of other natural resources, e.g., coal and oil.
} 
Table 21. Life cycle inventory for burning versus diverting bagasse to ethanol: Summary for enzyme process

\begin{tabular}{|c|c|c|c|c|c|}
\hline & Flow & Units & $\begin{array}{c}\text { Scenario 1: } \\
\text { Burning }+ \\
\text { Gasoline use }\end{array}$ & $\begin{array}{c}\text { Scenario 2: } \\
\text { Ethanol } \\
\text { Production }+ \\
\text { E10 use } \\
\end{array}$ & $\begin{array}{c}\text { Change from } \\
\text { Scenario 1 to } \\
\text { Scenario } 2\end{array}$ \\
\hline & & & \multicolumn{2}{|c|}{ Per $t$ of bagasse } & $\%$ \\
\hline \multirow[t]{5}{*}{ Inflows } & Coal (in ground) & $\mathrm{kg}$ & 5.5 & -100.7 & 1938 \\
\hline & Lignite (in ground) & $\mathrm{kg}$ & 0.02 & -0.01 & 149 \\
\hline & Natural gas (in ground) & $\mathrm{kg}$ & 17.7 & 23.1 & -30 \\
\hline & Oil (in ground) & $\mathrm{kg}$ & 172.9 & 4.4 & 98 \\
\hline & Water used (total) & liter & 761 & -73 & 110 \\
\hline \multicolumn{6}{|c|}{ Outflows } \\
\hline \multirow[t]{10}{*}{$\underline{\text { Air }}$} & Carbon Dioxide ( $\mathrm{CO}_{2}$, biomass $)$ & $\mathrm{kg}$ & 1,706 & 1,625 & 5 \\
\hline & Carbon Dioxide $\left(\mathrm{CO}_{2}\right.$, fossil $)$ & $\mathrm{kg}$ & 521 & -77 & 115 \\
\hline & Carbon Monoxide (CO) & $\mathrm{g}$ & 69 & 23 & 66 \\
\hline & Hydrocarbons (except methane) & $\mathrm{g}$ & 8.7 & 10.2 & -17 \\
\hline & Lead $(\mathrm{Pb})$ & $\mathrm{g}$ & 30.9 & -0.14 & 101 \\
\hline & Methane $\left(\mathrm{CH}_{4}\right)$ & $\mathrm{g}$ & 8,465 & -149 & 102 \\
\hline & Nitrogen Oxides $\left(\mathrm{NO}_{\mathrm{x}}\right.$ as $\left.\mathrm{NO}_{2}\right)$ & $\mathrm{kg}$ & 8.5 & 4.5 & 47 \\
\hline & Nitrous Oxide $\left(\mathrm{N}_{2} \mathrm{O}\right)$ & $\mathrm{g}$ & 20 & 21 & -3 \\
\hline & Particulates (uns & $\mathrm{g}$ & 4,195 & 148 & 97 \\
\hline & Sulfur Oxides $\left(\mathrm{SO}_{\mathrm{x}}\right.$ as $\left.\mathrm{SO}_{2}\right)$ & $\mathrm{g}$ & 2,622 & 1,774 & 32 \\
\hline \multirow[t]{4}{*}{ Water } & COD (Chemical Oxygen & $\mathrm{g}$ & 25.8 & 123.8 & -381 \\
\hline & Demand) & & & & \\
\hline & Lead $\left(\mathrm{Pb}^{++}, \mathrm{Pb}^{4+}\right)$ & $\mathrm{g}$ & 0.0085 & -0.0034 & 140 \\
\hline & Nitrates $\left(\mathrm{NO}^{3-}\right)$ & $\mathrm{g}$ & 2.3 & -0.05 & 102 \\
\hline \multirow[t]{3}{*}{$\underline{\text { Solid }}$} & Waste: total & $\mathrm{kg}$ & 41.0 & -13.7 & 134 \\
\hline & Waste: hazardou & $\mathrm{kg}$ & 0.20 & -0.01 & 107 \\
\hline & Waste: radioactive total & $\mathrm{kg}$ & 0.017 & -0.0002 & 101 \\
\hline \multirow[t]{4}{*}{$\overline{\text { Energy }}$} & Process energy & $\overline{\mathrm{MJ}}$ & 21,114 & 12,625 & 40 \\
\hline & Nonrenewable energy & MJ & 8,508 & 226 & 97 \\
\hline & Renewable energy & MJ & 8.4 & 18,841 & $\mathrm{NM}^{\mathrm{a}}$ \\
\hline & Total primary energy & MJ & 27,517 & 19,068 & 31 \\
\hline
\end{tabular}

${ }^{\mathrm{a}}$ Not meaningful to report.

Table 22. Natural gas consumption and CODs for key modules

\begin{tabular}{lccc}
\hline & Basis & Natural gas, & COD, \\
\hline Ammonia & $1 \mathrm{~kg}$ & 0.91 & 3.72 \\
Sulfuric acid & $1 \mathrm{~kg}$ & 0.04 & $1.4 \times 10^{-5}$ \\
Lime & $1 \mathrm{~kg}$ & 0.10 & $2.6 \times 10^{-5}$ \\
Diesel production & $1 \mathrm{~kg}$ & 0.14 & 3.47 \\
Gasoline production & $1 \mathrm{~kg}$ & 0.11 & 0.17 \\
Steam & $1 \mathrm{~kg}$ & 0.063 & 0.002 \\
Electricity & $1 \mathrm{MJ}$ & 0.053 & $2.1 \times 10^{-4}$ \\
\hline
\end{tabular}




\subsubsection{Resource Depletion}

Depletion of nonrenewable resources is an important criterion in judging alternative scenarios. Coal and lignite usage is negative for Scenario 2 due to offset credits from excess electricity (Figure 8). Natural gas usage is higher (Figure 9) and crude oil usage is significantly lower (Figure 10) for Scenario 2 compared to Scenario 1. The reason that natural gas usage is higher for Scenario 2 is because of the ammonia use during ethanol production, which is absent in Scenario 1 (see Table 22). Water usage is also is negative for Scenario 2 owing to offset credits (Figure 11). Depletion of non-renewable resources is also captured in impact assessment (section 9.8).

\subsubsection{Air Pollutants}

$\mathrm{CO}$ emissions for Scenario 2 are a third of those for Scenario 1, which is a significant benefit for Scenario 2 (Figure 12). Nonmethane hydrocarbon emissions are slightly higher for Scenario 2 than those for Scenario 1 (Figure 13). About half of the Scenario 2 hydrocarbon emissions are from ethanol, furfural, and hydroxy-methyl-furfural (HMF) emitted during ethanol production, which is absent in Scenario 1. $\mathrm{SO}_{\mathrm{x}}$ emissions for Scenario 2 are lower by about $30 \%$, while $\mathrm{NO}_{\mathrm{x}}$ emissions for Scenario 2 are lower by about 50\% (Figure 14 and Figure 15). Also, particulate emissions are lower for Scenario 2 by a factor of about 30, again a large reduction for an important air pollutant (Figure 16). It should be noted that most of the particulate emissions and a bulk of the $\mathrm{CO}$ emissions are from biomass burning in Scenario 1. Lead emissions are lower for Scenario 2 due to the partial displacement of gasoline by ethanol (Figure 17).

\subsubsection{Waste Generation}

Nitrates and lead (water-borne) emissions are lower but COD values are significantly higher for Scenario 2 compared to those for Scenario 1. The higher COD values for Scenario 2 stem from the ethanol production step. However, water emissions do not occur during the actual process, but rather during upstream production of raw materials used in the process, e.g., ammonia, sulfuric acid, lime, etc. As shown in Table 22, COD values are especially high for ammonia, which is used only in Scenario 2. Moreover, electricity offsets for COD are very low.

Total solid waste, hazardous waste, and radioactive waste are lower for Scenario 2 compared to that for Scenario 1. Lime is a big contributor to the total solid waste, while ammonia and sulfuric acid also are responsible for some of the waste generation. These raw materials are used only in Scenario 2. In spite of this, solid wastes are lower for Scenario 2 compared to those for Scenario 1 , mainly because of electricity offsets.

\subsubsection{Energy Consumption and GHGs}

Due to electricity offset credits, negative $\mathrm{CO}_{2}$ and $\mathrm{CH}_{4}$ emissions are encountered, thereby more than mitigating all the $\mathrm{CO}_{2}$ and methane emissions from Scenario 1 (Figure 18 and Figure 19). The slightly higher nitrous oxide emissions for Scenario 2, if considered significant, can be explained by the use of diesel in transporting bagasse. This burden is absent in Scenario 1, and electricity offsets do not affect nitrous oxide emissions. Process energy required is less for Scenario 2 by $40 \%$ (Figure 20), and its nonrenewable energy consumption is $97 \%$ lower compared to that for Scenario 1 (Figure 21). As expected, the renewable energy consumption is very high for Scenario 2 and very low for Scenario 1. 


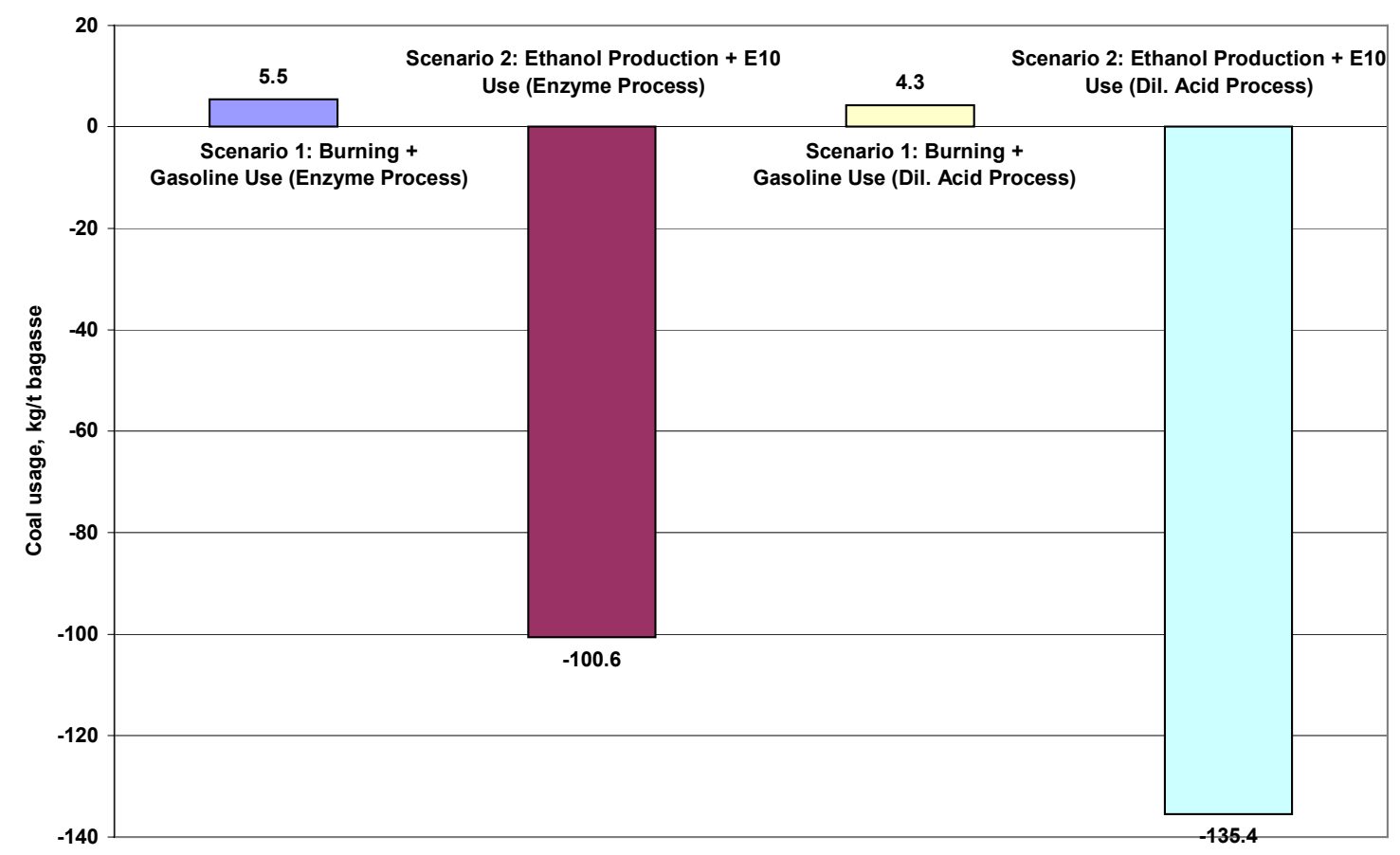

Figure 8. Comparison of burning versus diverting bagasse to ethanol: Coal usage.

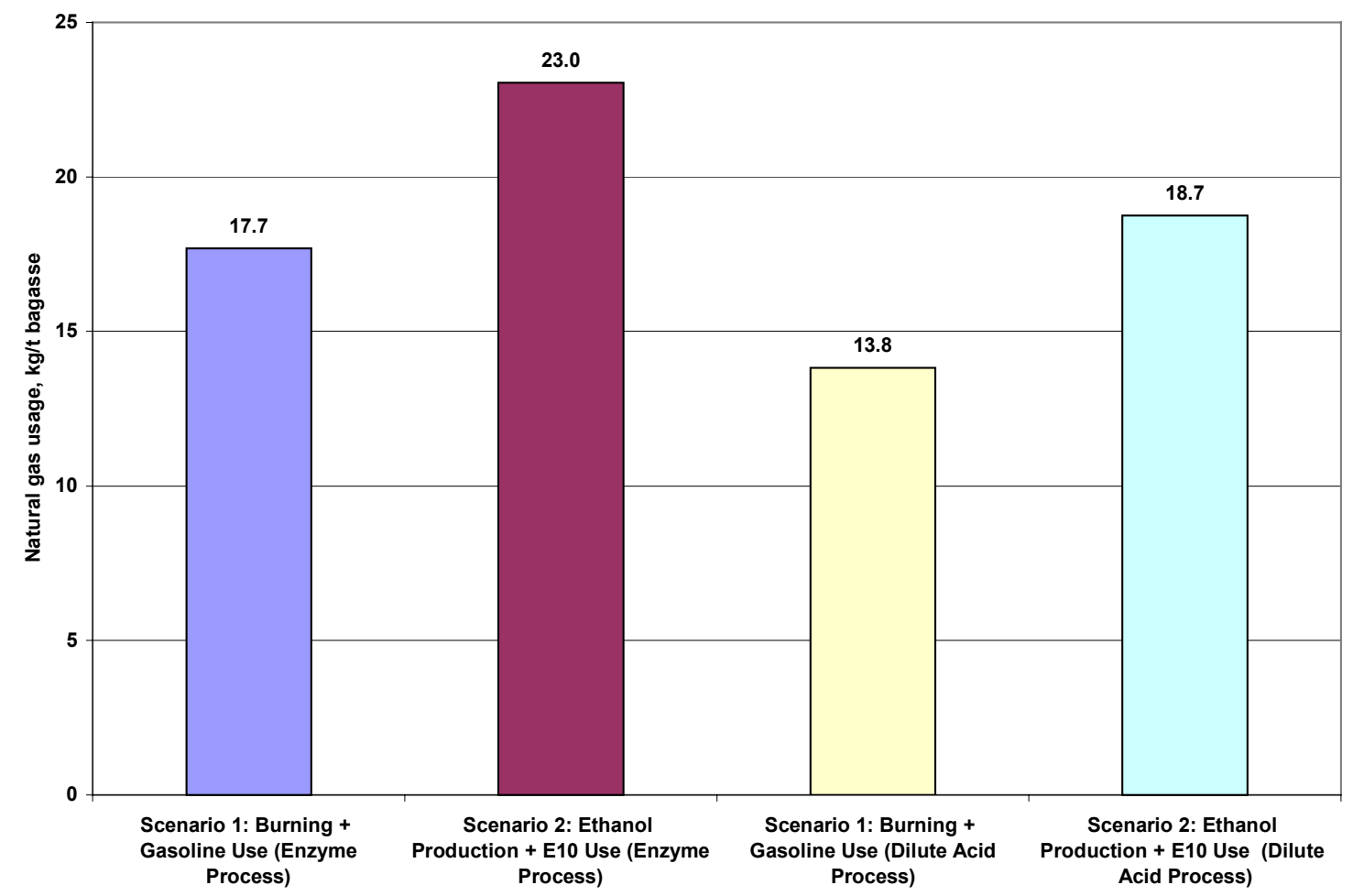

Figure 9. Comparison of burning versus diverting bagasse to ethanol: Natural gas usage. 


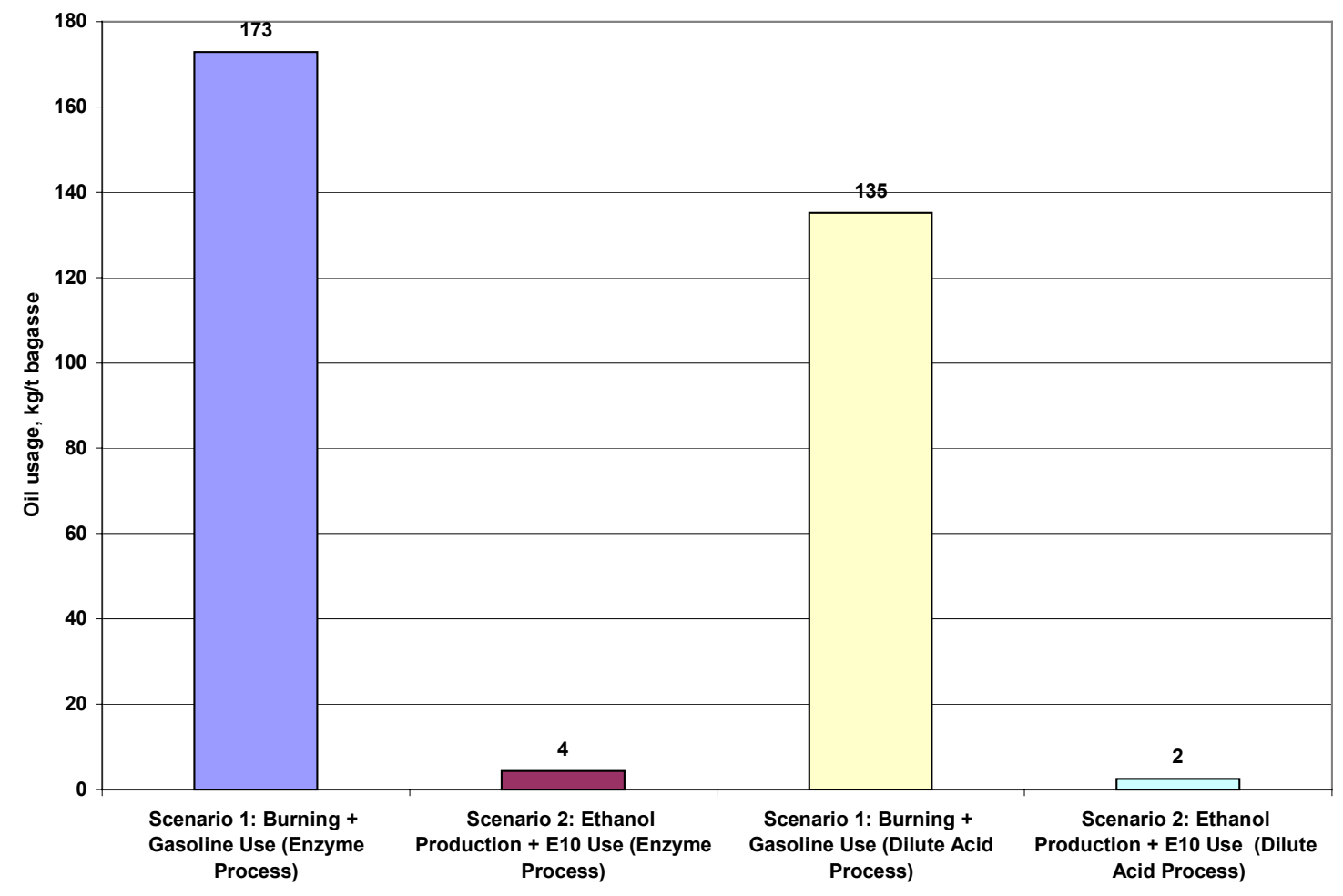

Figure 10. Comparison of burning versus diverting bagasse to ethanol: Crude oil usage.

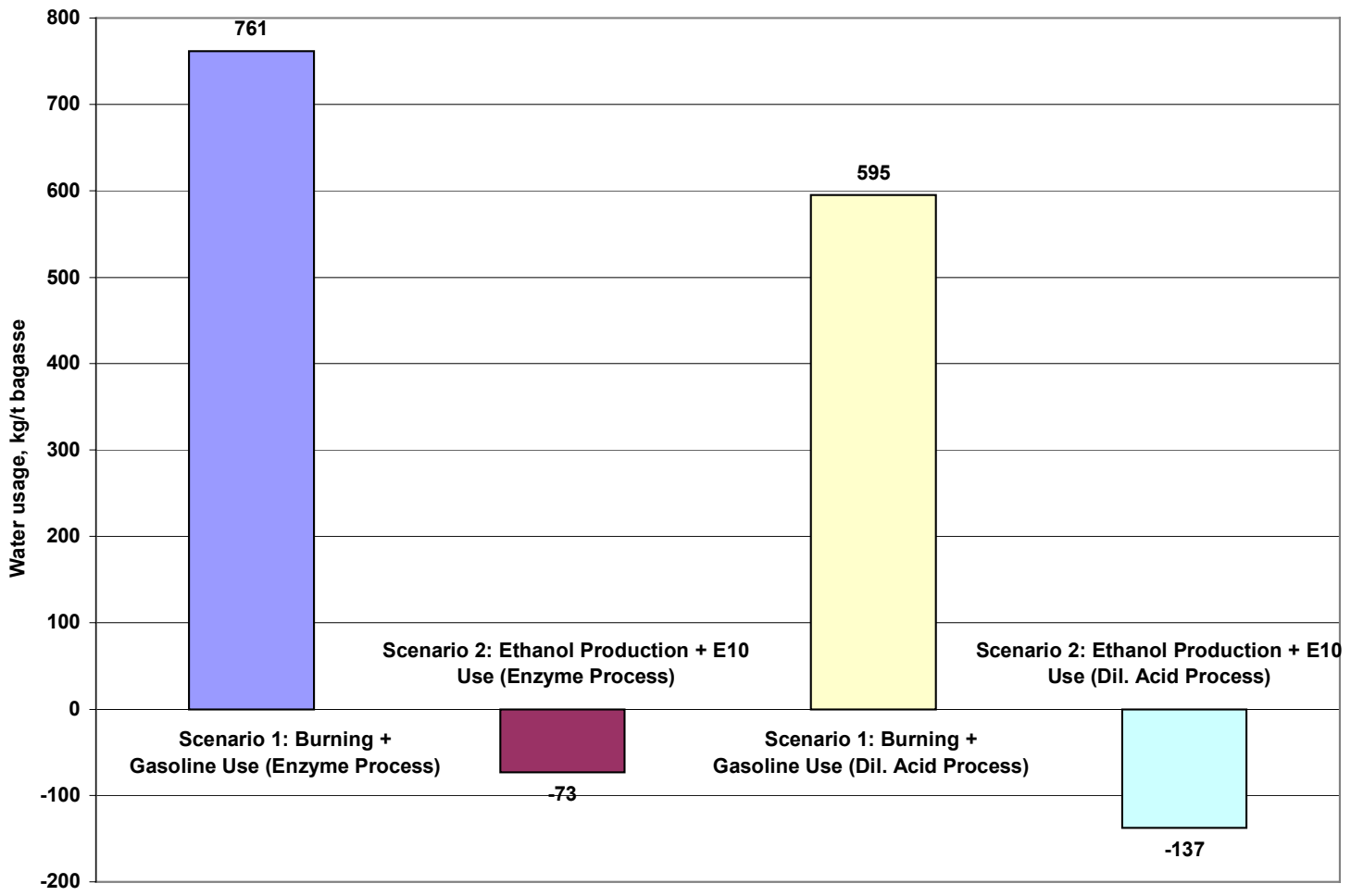

Figure 11. Comparison of burning versus diverting bagasse to ethanol: Water usage. 


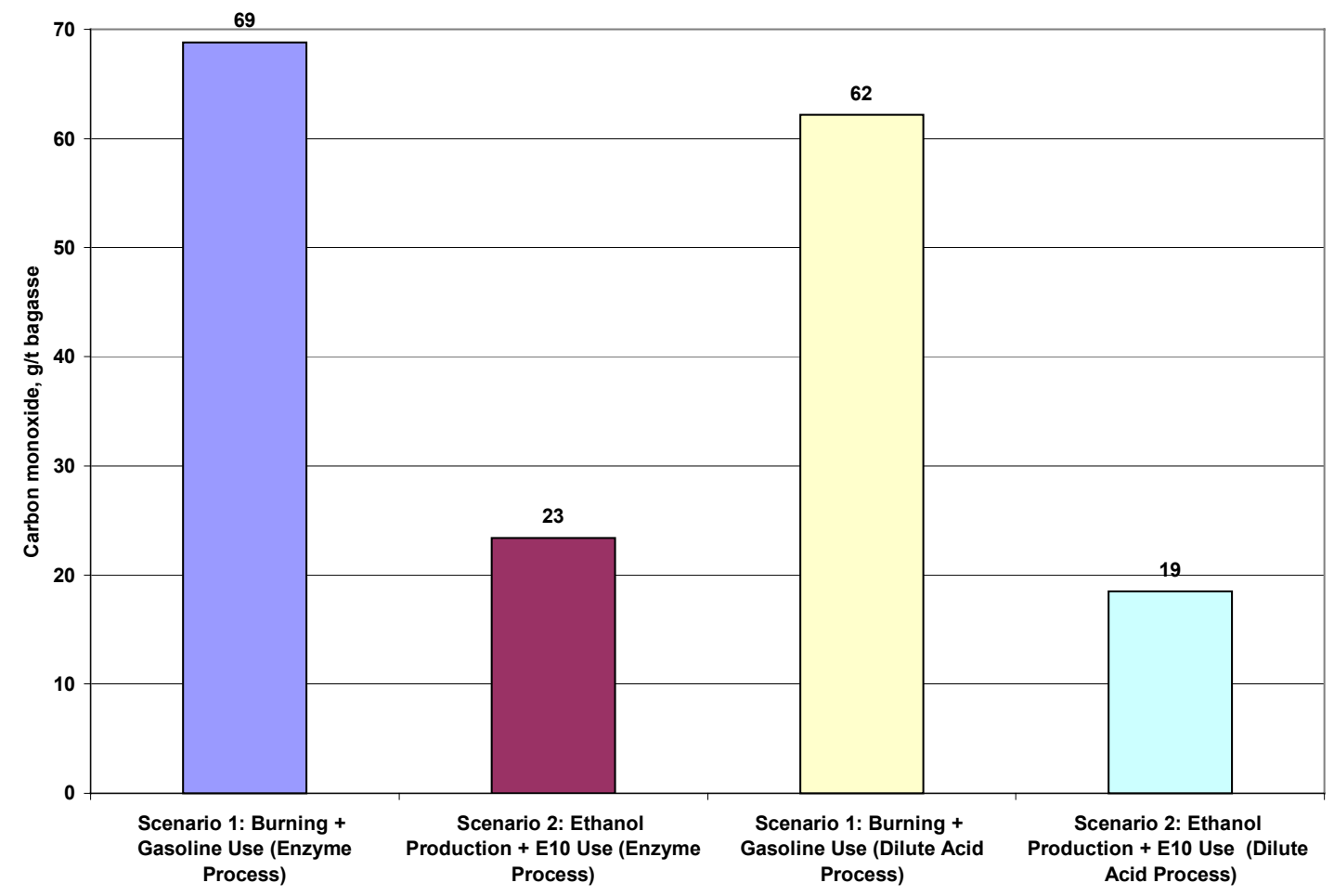

Figure 12. Comparison of burning versus diverting bagasse to ethanol: Carbon monoxide emissions.

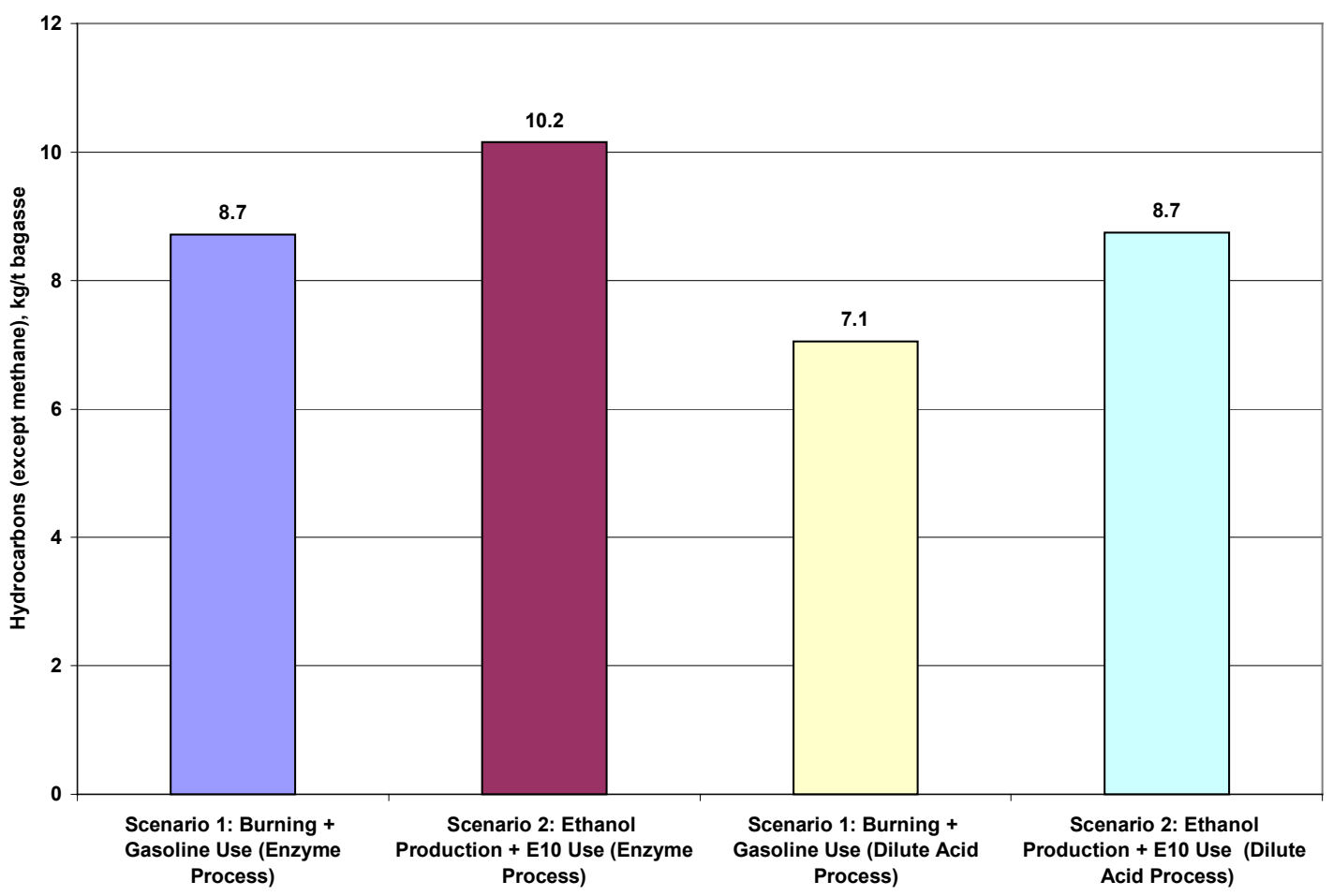

Figure 13. Comparison of burning versus diverting bagasse to ethanol: Hydrocarbon (except methane) emissions. 


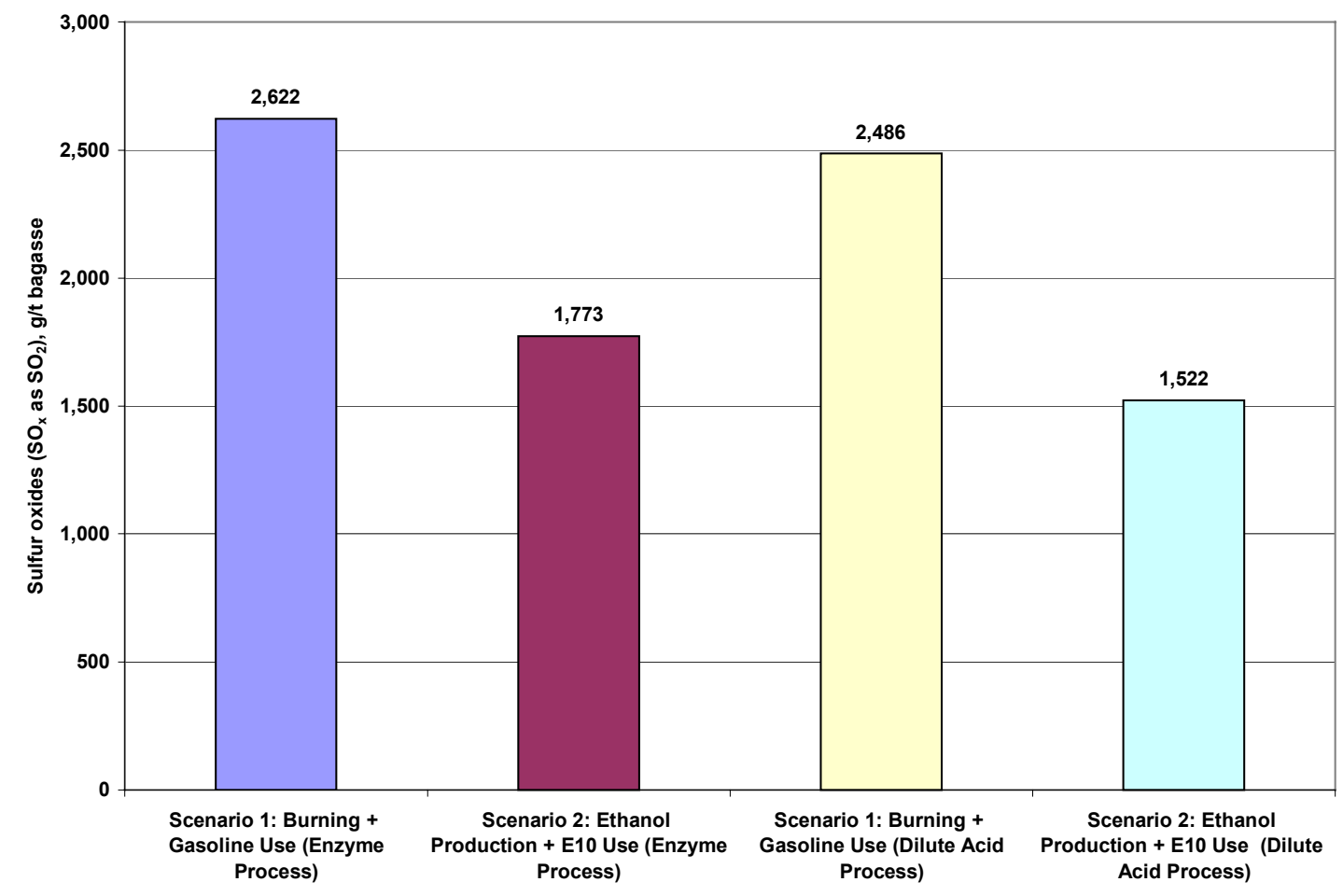

Figure 14. Comparison of burning versus diverting bagasse to ethanol: Sulfur oxides $\left(\mathrm{SO}_{\mathrm{x}}\right.$ as $\mathrm{SO}_{2}$ ) emissions.

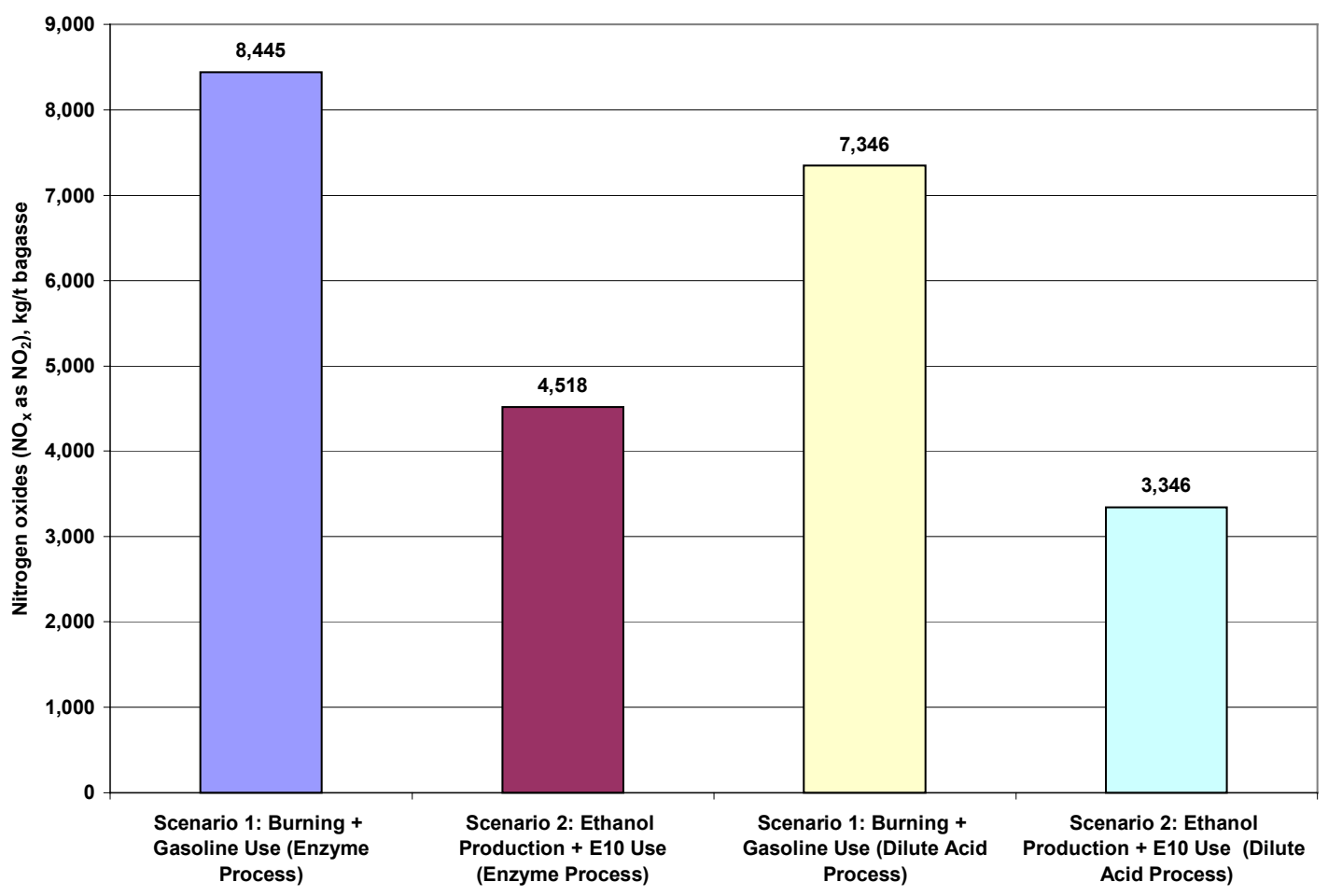

Figure 15. Comparison of burning versus diverting bagasse to ethanol: Nitrogen oxides $\left(\mathrm{NO}_{\mathrm{x}}\right.$ as $\left.\mathrm{NO}_{2}\right)$ emissions. 


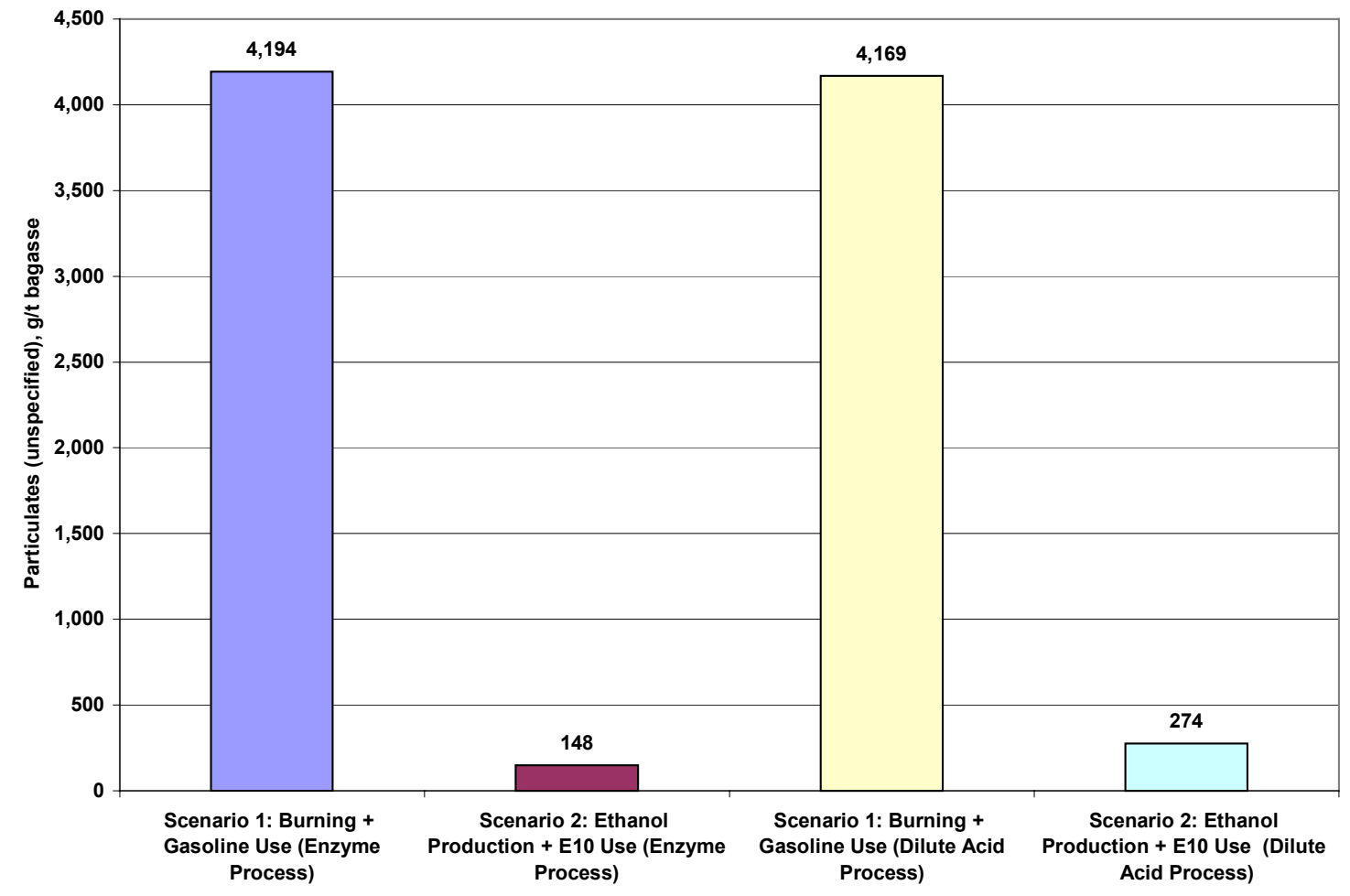

Figure 16. Comparison of burning versus diverting bagasse to ethanol: Particulate matter (unspecified) emissions.

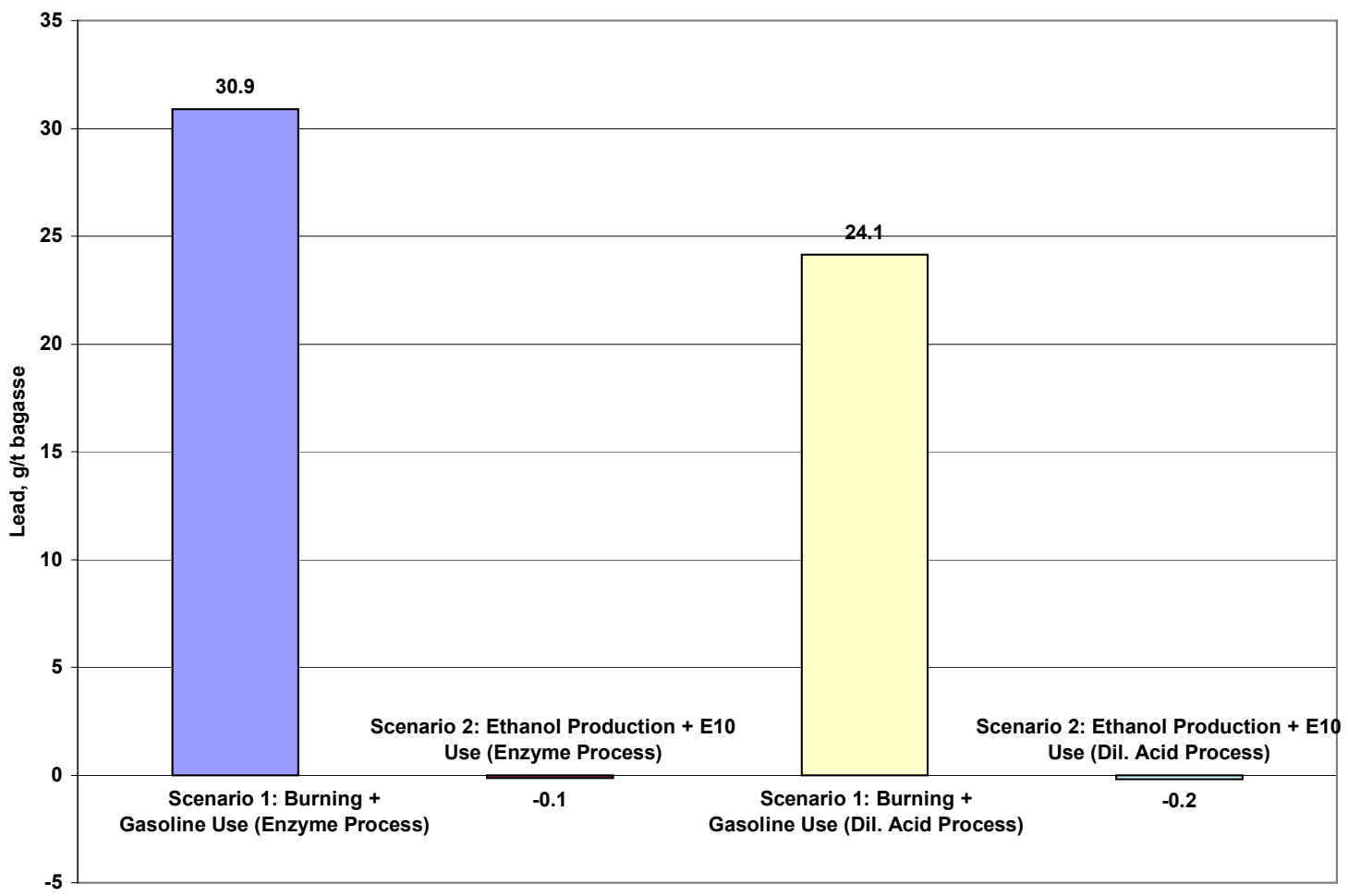

Figure 17. Comparison of burning versus diverting bagasse to ethanol: Lead emissions. 


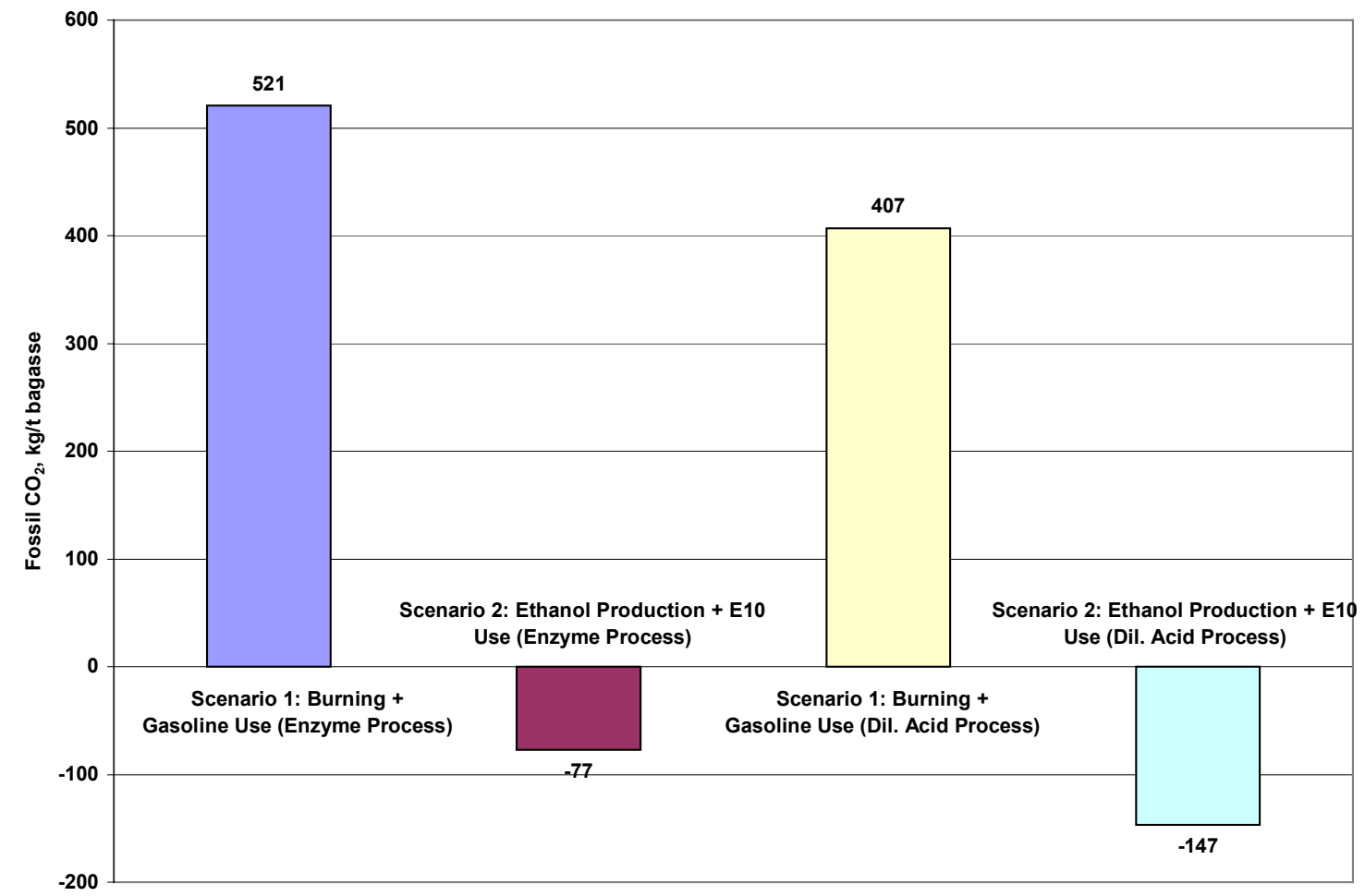

Figure 18. Comparison of burning versus diverting bagasse to ethanol: Fossil $\mathrm{CO}_{2}$ emissions.

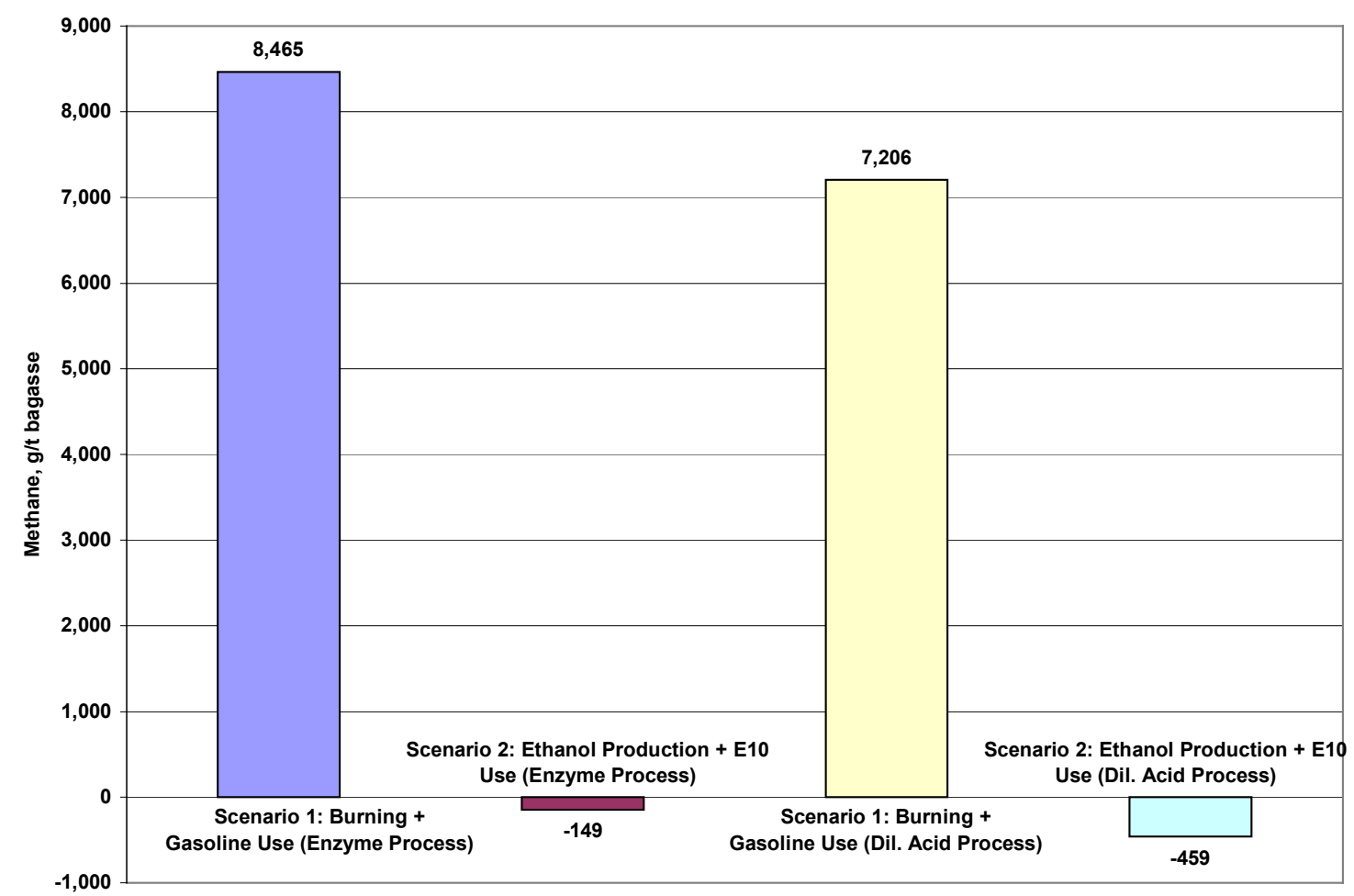

Figure 19. Comparison of burning versus diverting bagasse to ethanol: Methane emissions. 


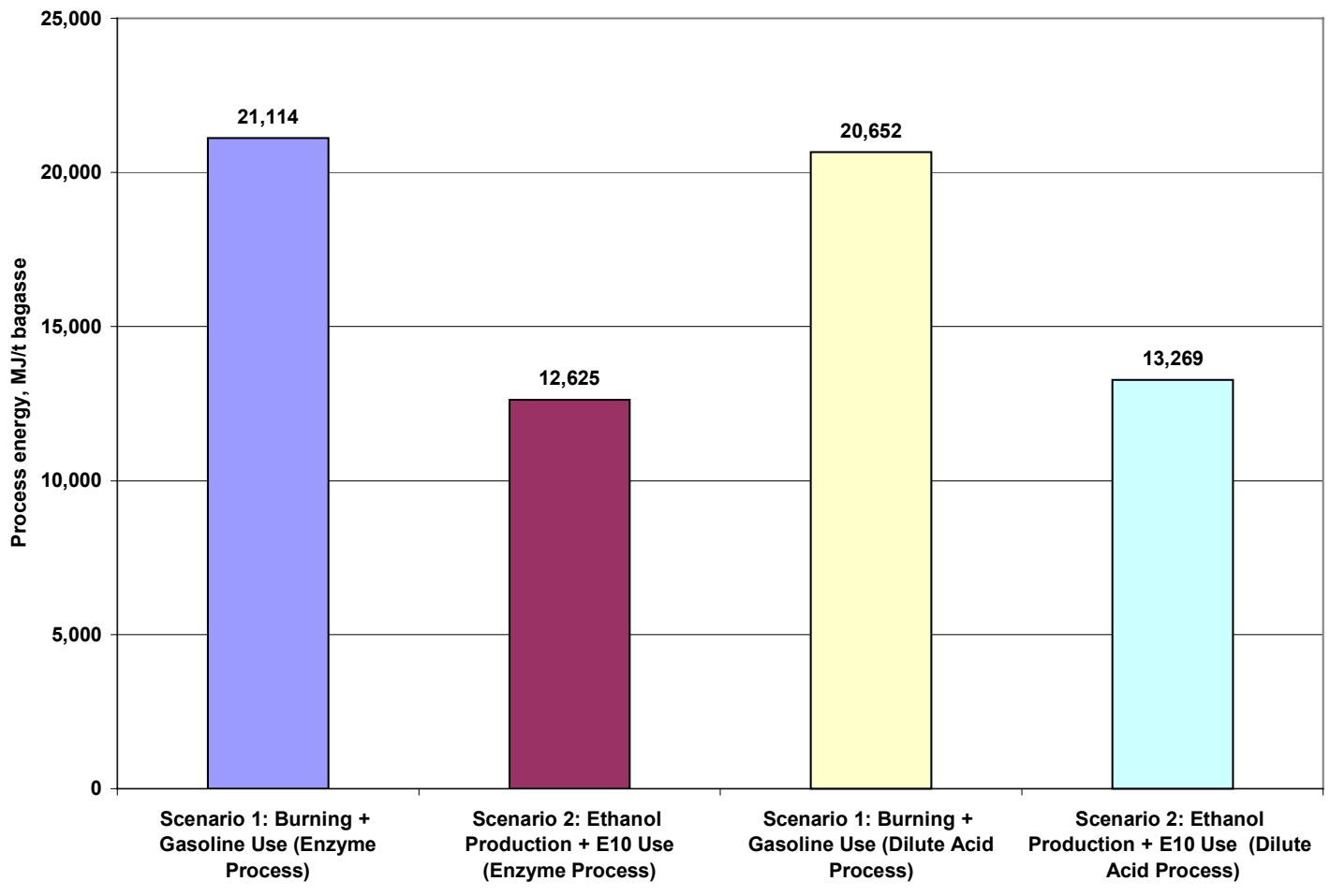

Figure 20. Comparison of burning versus diverting bagasse to ethanol: Process energy usage.

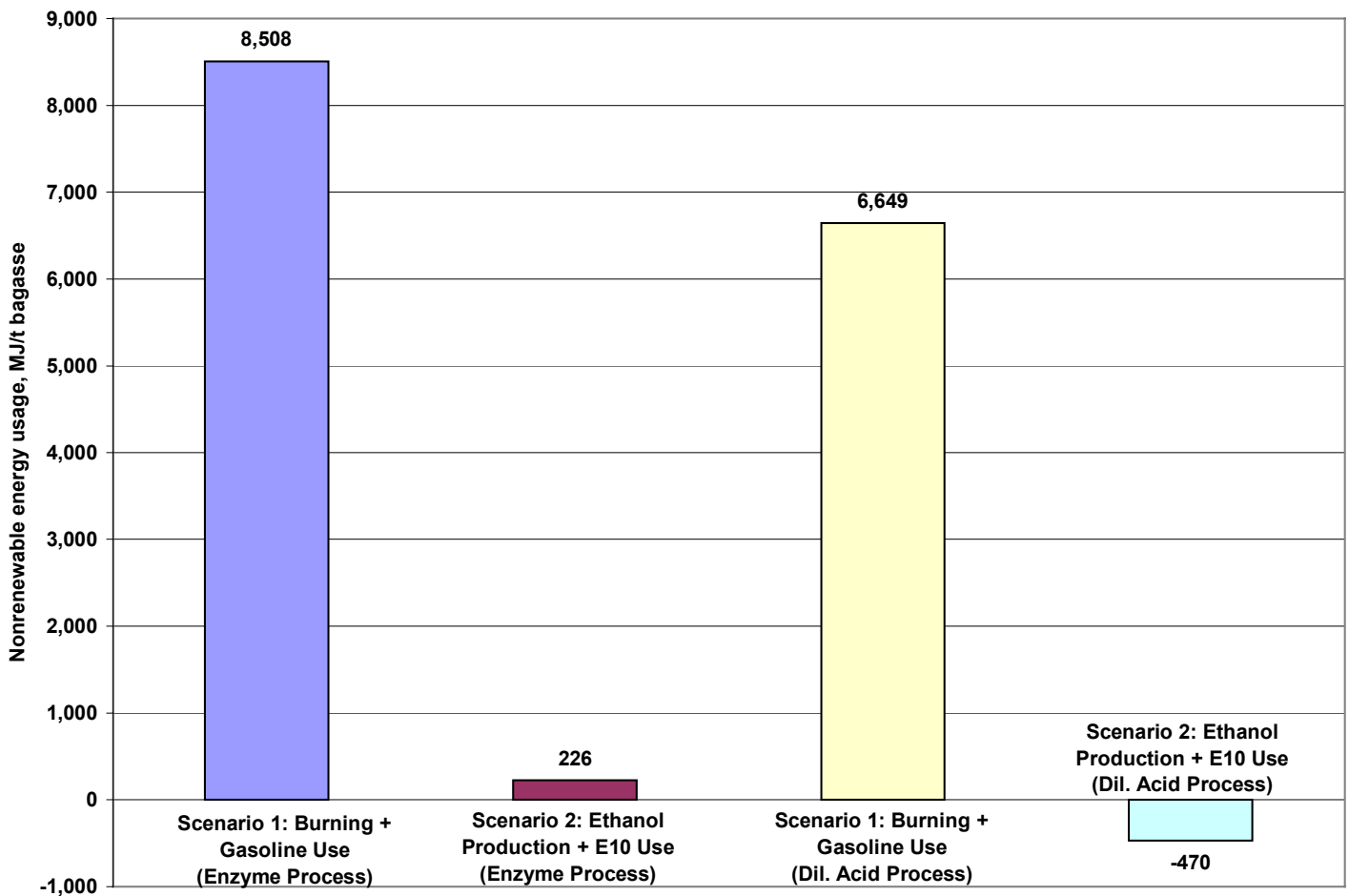

Figure 21. Comparison of burning versus diverting bagasse to ethanol: Nonrenewable energy usage. 


\subsection{LCI for Burning versus Diverting Bagasse to Ethanol: Dilute Acid Process}

Similar results for key environmental flows are obtained using the dilute acid process (Table 23), the specific changes from Scenario 1 to Scenario 2 being affected by the inherent differences in the two processes.

Table 23. Life cycle inventory for burning versus diverting bagasse to ethanol: Summary for dilute acid process

\begin{tabular}{|c|c|c|c|c|c|}
\hline & & Units & $\begin{array}{c}\text { Scenario 1: } \\
\text { Burning + } \\
\text { Gasoline use }\end{array}$ & $\begin{array}{c}\text { Scenario 2: } \\
\text { Ethanol } \\
\text { Production }+ \\
\text { E10 use } \\
\end{array}$ & $\begin{array}{c}\text { Change from } \\
\text { Scenario } 1 \text { to } \\
\text { Scenario } 2\end{array}$ \\
\hline & & & Per to & f bagasse & $\%$ \\
\hline \multirow[t]{5}{*}{ Inflows } & Coal (in ground) & $\mathrm{kg}$ & 4.3 & -135.4 & 3265 \\
\hline & Lignite (in ground) & $\mathrm{kg}$ & 0.017 & -0.014 & 184 \\
\hline & Natural gas (in ground) & $\mathrm{kg}$ & 13.8 & 18.8 & -36 \\
\hline & Oil (in ground) & $\mathrm{kg}$ & 135 & 2.5 & 98 \\
\hline & Water used (total) & liter & 595 & -137 & 123 \\
\hline \multicolumn{6}{|c|}{$\overline{\text { Outflows }}$} \\
\hline \multirow[t]{10}{*}{$\underline{\text { Air }}$} & Carbon Dioxide $\left(\mathrm{CO}_{2}\right.$, biomass $)$ & $\mathrm{kg}$ & 1,706 & 1,663 & 3 \\
\hline & Carbon Dioxide $\left(\mathrm{CO}_{2}\right.$, fossil $)$ & $\mathrm{kg}$ & 407 & -147 & 136 \\
\hline & Carbon Monoxide (CO) & $\mathrm{g}$ & 62 & 19 & 70 \\
\hline & Hydrocarbons (except methane) & $\mathrm{g}$ & 7.1 & 8.8 & -24 \\
\hline & Lead $(\mathrm{Pb})$ & $\mathrm{g}$ & 24 & -0.2 & 101 \\
\hline & Methane $\left(\mathrm{CH}_{4}\right)$ & $\mathrm{g}$ & 7,206 & -459 & 106 \\
\hline & Nitrogen Oxides $\left(\mathrm{NO}_{\mathrm{x}}\right.$ as $\left.\mathrm{NO}_{2}\right)$ & $\mathrm{kg}$ & 7.4 & 3.4 & 55 \\
\hline & Nitrous Oxide $\left(\mathrm{N}_{2} \mathrm{O}\right)$ & $\mathrm{g}$ & 16.0 & 15.6 & 2 \\
\hline & Particulates (unspecified) & $\mathrm{g}$ & 4,169 & 274 & 93 \\
\hline & Sulfur Oxides $\left(\mathrm{SO}_{\mathrm{x}}\right.$ as $\left.\mathrm{SO}_{2}\right)$ & $\mathrm{kg}$ & 2.5 & 1.5 & 39 \\
\hline \multirow[t]{3}{*}{$\underline{\text { Water }}$} & $\begin{array}{l}\text { COD (Chemical Oxygen } \\
\text { Demand) }\end{array}$ & $\mathrm{g}$ & 20 & 109 & -442 \\
\hline & Lead $\left(\mathrm{Pb}^{++}, \mathrm{Pb}^{4+}\right)$ & $\mathrm{g}$ & 0.0067 & -0.0046 & 168 \\
\hline & Nitrates $\left(\mathrm{NO}^{3-}\right)$ & $\mathrm{g}$ & 1.8 & -0.1 & 104 \\
\hline \multirow[t]{3}{*}{$\underline{\text { Solid }}$} & Waste: total & $\mathrm{kg}$ & 40 & 5 & 88 \\
\hline & Waste: hazardous & $\mathrm{kg}$ & 0.16 & -0.02 & 112 \\
\hline & Waste: radioactive total & $\mathrm{kg}$ & 0.01 & -0.0003 & 102 \\
\hline \multirow[t]{4}{*}{ Energy } & Process energy & $\mathrm{MJ}$ & 20,652 & 13,269 & 36 \\
\hline & Nonrenewable energy & MJ & 6,649 & -470 & 107 \\
\hline & Renewable energy & MJ & 6.6 & 18,787 & $\mathrm{NM}^{\mathrm{a}}$ \\
\hline & Total primary energy & MJ & 25,656 & 18,317 & 29 \\
\hline
\end{tabular}

${ }^{\mathrm{a}}$ Not meaningful to report. 


\subsubsection{Resource Depletion}

Coal, lignite, and water usage is again negative due to offset credits. Natural gas usage is again higher; however, crude oil usage is significantly lower. The reason for higher natural gas usage is the same as in the case of the enzyme process.

\subsubsection{Air Pollutants}

$\mathrm{CO}_{2}$ emissions for Scenario 2 are again a third of those for Scenario 1. Also, particulate emissions are lower for Scenario 2 by a factor of about 15. As in the case of the enzyme process, most of the particulate and $\mathrm{CO}_{2}$ emissions are from biomass burning in Scenario 1. $\mathrm{SO}_{\mathrm{x}}$ emissions for Scenario 2 are lower by a factor of about 2, while $\mathrm{NO}_{\mathrm{x}}$ emissions for Scenario 2 are lower by $55 \%$. In general, reductions are higher for the dilute acid process as compared to the enzyme process, because of the higher offsets enjoyed by the former. More of the bagasse is sent as fuel residue to the boiler. This leads to lower $\mathrm{SO}_{\mathrm{x}}, \mathrm{NO}_{\mathrm{x}}$, and fossil $\mathrm{CO}_{2}$ emissions because of the correspondingly high electricity offset credits. Again, about $50 \%$ of the Scenario 2 hydrocarbon emissions are from ethanol, furfural, and HMF emitted during ethanol production, which yields higher hydrocarbon emissions for Scenario 2 compared to Scenario 1.

\subsubsection{Waste Generation}

As in the enzyme case, COD values are significantly higher for Scenario 2 compared to those for Scenario 1. The explanation given above for higher COD values for Scenario 2 applies here as well.

Total solid waste, hazardous waste, and radioactive waste are again lower for Scenario 2 compared to that for Scenario 1, but the decrease for Scenario 2 is lower than that for the enzyme case. This is because the acid process uses more lime than the enzyme process, and lime is the single largest contributor to total solid waste generation.

\subsubsection{Energy Consumption and GHGs}

Process energy required is less for Scenario 2 by $36 \%$ compared to that for Scenario 1 . As in the enzyme case, the nonrenewable energy offset yields a negative value for Scenario 2 giving negative $\mathrm{CO}_{2}$ and methane emissions. The nitrous oxide emissions are about the same for both scenarios.

\subsection{LCIA for Burning versus Diverting Bagasse to Ethanol}

In addition to the environmental flows, impact indicator values were also calculated for the above scenarios. These indicators are used to give a broader insight into the environmental impacts of the competing scenarios, by examining the potential impacts beyond the initial release. The indices calculated are greenhouse potential, natural resources depletion, acidification potential, eutrophication potential, human toxicity potential, air odor potential, and ozone-forming potential (see Appendix B for definitions). It should be emphasized that only fossil $\mathrm{CO}_{2}$ was taken into account in calculating greenhouse potential. Table 24 and Table 25 give the overall values for these impact indicators. It is evident from these tables that for all the indicators, Scenario 1 is worse than Scenario 2, using either of the ethanol production schemes, 
with the exception of the EPA-maximum incremental reactivity potential, the reason for which is explained later.

Table 24. Life cycle impact assessment for burning versus diverting bagasse to ethanol: Summary for enzyme process

\begin{tabular}{|c|c|c|c|c|}
\hline Impact & Units & $\begin{array}{c}\text { Scenario 1: } \\
\text { Burning + } \\
\text { Gasoline Use }\end{array}$ & $\begin{array}{c}\text { Scenario 2: } \\
\text { Ethanol } \\
\text { Production + } \\
\text { E10 Use } \\
\end{array}$ & $\begin{array}{l}\text { Change from } \\
\text { Scenario } 1 \text { to } \\
\text { Scenario } 2\end{array}$ \\
\hline & & \multicolumn{2}{|c|}{ Per $t$ of bagasse } & $\%$ \\
\hline $\begin{array}{l}\text { IPCC-Greenhouse effect } \\
\quad(\text { direct, } 100 \text { years })^{\mathrm{a}}\end{array}$ & $\begin{array}{l}\text { kg equivalent } \\
\mathrm{CO}_{2}\end{array}$ & 731 & -73 & 110 \\
\hline $\begin{array}{l}\text { Depletion of nonrenewable } \\
\text { resources }(\mathrm{CML})^{\mathrm{b}}\end{array}$ & $\begin{array}{l}\text { fraction of } \\
\text { reserve }\end{array}$ & $8.7 \times 10^{-13}$ & $1.5 \times 10^{-13}$ & 82 \\
\hline Air acidification $(\mathrm{CML})^{\mathrm{b}}$ & g equivalent $\mathrm{H}^{+}$ & 266 & 155 & 42 \\
\hline Eutrophication $(\mathrm{CML})^{\mathrm{b}}$ & g equivalent $\mathrm{PO}_{4}$ & 1,120 & 596 & 47 \\
\hline Human toxicity (CML) ${ }^{b}$ & $\begin{array}{l}\mathrm{kg} \text { toxic } \\
\text { compounds }\end{array}$ & 16.8 & 5.7 & 66 \\
\hline Air odor $(\mathrm{CML})^{\mathrm{b}}$ & $\mathrm{m}^{3}$ air & 609 & -611 & 200 \\
\hline $\begin{array}{l}\text { EPA-Maximum incremental } \\
\text { reactivity potential }\end{array}$ & $\begin{array}{l}\mathrm{kg} \text { ozone } \\
\text { equivalent }\end{array}$ & 4.7 & 6.4 & -36 \\
\hline
\end{tabular}

\subsubsection{Greenhouse Potential}

The greenhouse potential values for Scenario 1 are predominantly larger than the values for Scenario 2 (see also Figure 22). The reason behind this is the higher fossil energy use in Scenario 1, which leads to higher fossil $\mathrm{CO}_{2}$ emissions. The difference between the two methods of producing ethanol is due to the higher electricity offsets for the acid process, i.e., higher credit for $\mathrm{CO}_{2}$ emissions.

\subsubsection{Natural Resource Depletion Potential}

The natural resource depletion values are driven to a large degree by how much of a designated natural resource the system consumes, e.g., coal, oil, phosphate, natural gas, uranium, bauxite, iron, etc. The natural resource depletion values for Scenario 1 are driven by gasoline production. Once again, the amount of lignin residue produced during ethanol production leads to electricity offsets, which results in a reduction in natural gas, oil, and coal consumption. Hence, natural resource depletion index for Scenario 1 is larger than that for Scenario 2 (see also Figure 23). 
Table 25. Life cycle impact assessment for burning versus diverting bagasse to ethanol: Summary for dilute acid process

\begin{tabular}{|c|c|c|c|c|}
\hline Impact & Units & $\begin{array}{c}\text { Scenario 1: } \\
\text { Burning }+ \\
\text { Gasoline use }\end{array}$ & $\begin{array}{c}\text { Scenario 2: } \\
\text { Ethanol } \\
\text { Production + } \\
\text { E10 use }\end{array}$ & $\begin{array}{c}\text { Change from } \\
\text { Scenario } 1 \text { to } \\
\text { Scenario } 2\end{array}$ \\
\hline & & \multicolumn{2}{|c|}{ Per $t$ of bagasse } & $\%$ \\
\hline $\begin{array}{l}\text { IPCC-Greenhouse effect } \\
\text { (direct, } 100 \text { years) }^{\mathrm{a}}\end{array}$ & $\begin{array}{l}\mathrm{kg} \text { equivalent } \\
\mathrm{CO}_{2}\end{array}$ & 586 & -152 & 126 \\
\hline $\begin{array}{l}\text { Depletion of nonrenewable } \\
\text { resources }(C M L)^{b}\end{array}$ & $\begin{array}{l}\text { fraction of } \\
\text { reserve }\end{array}$ & $6.8 \times 10^{-13}$ & $9.5 \times 10^{-13}$ & 86 \\
\hline Air acidification $(\mathrm{CML})^{\mathrm{b}}$ & g equivalent $\mathrm{H}^{+}$ & 238 & 120 & 49 \\
\hline Eutrophication $(\mathrm{CML})^{\mathrm{b}}$ & $\mathrm{g}$ equivalent $\mathrm{PO}_{4}$ & 972 & 441 & 55 \\
\hline Human toxicity $(\mathrm{CML})^{\mathrm{b}}$ & $\begin{array}{l}\mathrm{kg} \text { toxic } \\
\text { compounds }\end{array}$ & 14.4 & 4.3 & 70 \\
\hline Air odor $(\mathrm{CML})^{\mathrm{b}}$ & $\mathrm{m}^{3}$ air & 476 & $-2,817$ & 692 \\
\hline $\begin{array}{l}\text { EPA-Maximum incremental } \\
\text { reactivity potential }\end{array}$ & $\begin{array}{l}\mathrm{kg} \text { ozone } \\
\text { equivalent }\end{array}$ & 4.2 & 5.7 & -37 \\
\hline
\end{tabular}

${ }^{\mathrm{a}} \mathrm{IPCC}=$ Intergovernment Panel on Climate Change, United Nations.

${ }^{\mathrm{b}} \mathrm{CML}=$ Centre of Environmental Science, Leiden University, The Netherlands.

\subsubsection{Air Acidification Potential}

Scenario 1 generates a larger acidification impact than the comparative ethanol production scenario (Figure 24). For Scenario 1, the use of electricity in gasoline production process generates most of the emissions that contribute to the acidification values. The burning of the bagasse itself also contributes to this impact value because bagasse has a relatively large sulfur content. However, both the scenarios experience the $\mathrm{SO}_{\mathrm{x}}$ release when either bagasse is burned (Scenario 1) or the lignin residue is burned during cogeneration (Scenario 2). Similar to the greenhouse potential, the air acidification indicator values are affected by the electricity offset from lignin-based cogeneration. This is because electrical plants generate large amounts of $\mathrm{SO}_{\mathrm{x}}$ and $\mathrm{NO}_{\mathrm{x}}$.

\subsubsection{Eutrophication Potential}

Eutrophication impact values are also higher for Scenario 1 than for Scenario 2 (Figure 25). The production of the fuel used to produce gasoline as well as that used during the transportation of the biomass were the main contributors to this value. The eutrophication values for Scenario 2 are also driven by the water-borne emissions from ethanol production. However, it is not the actual process that is the driver, but rather the upstream emissions from the production of raw materials used in the process (e.g., ammonia, sulfuric acid, lime, etc.). It should be noted that, unlike in the case of air-related impacts, the eutrophication potential is not greatly affected by the higher electricity offset credits. Despite this, Scenario 2 has lower eutrophication potential. 


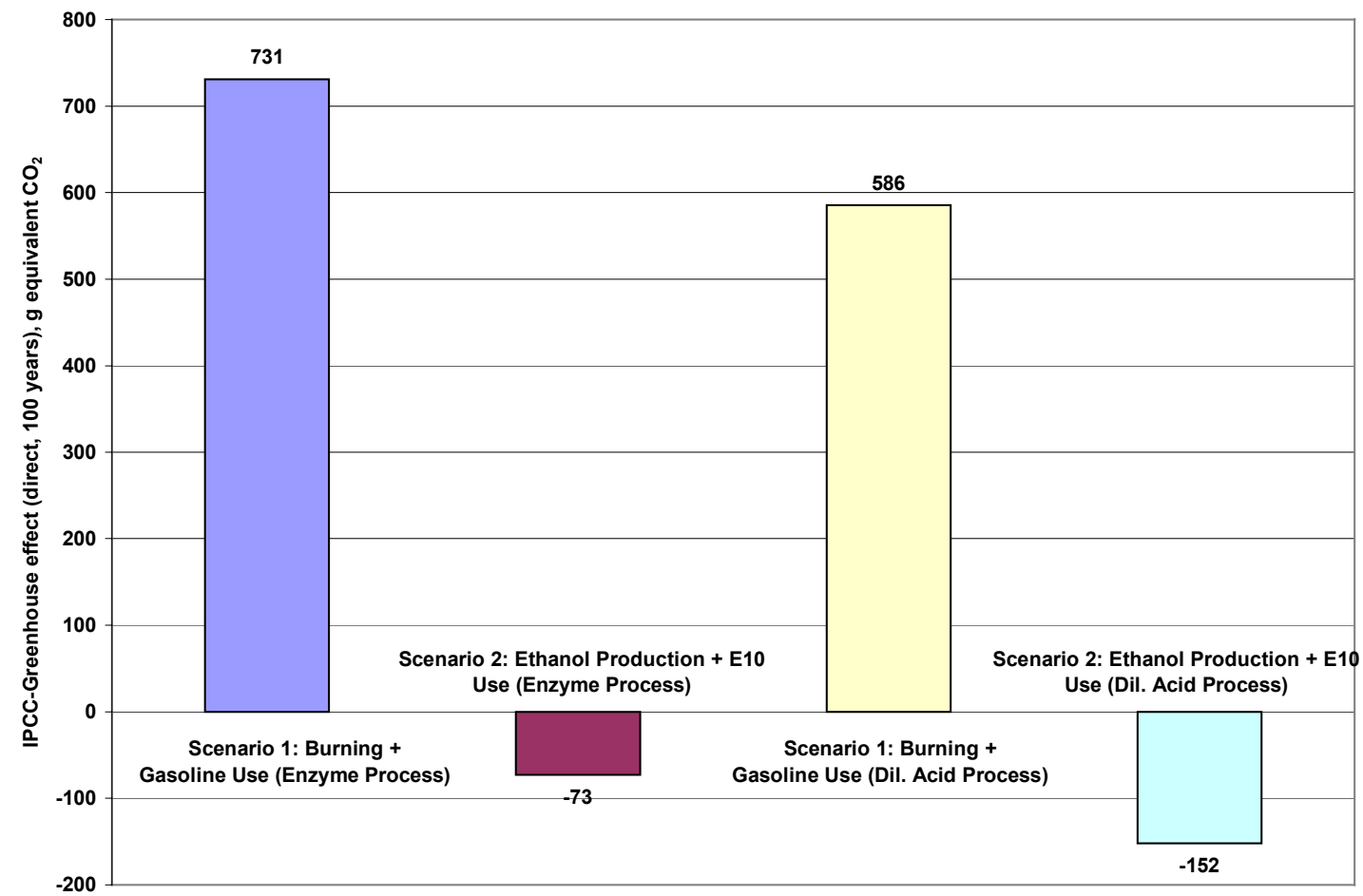

Figure 22. Comparison of burning versus diverting bagasse to ethanol: Greenhouse effect potential.

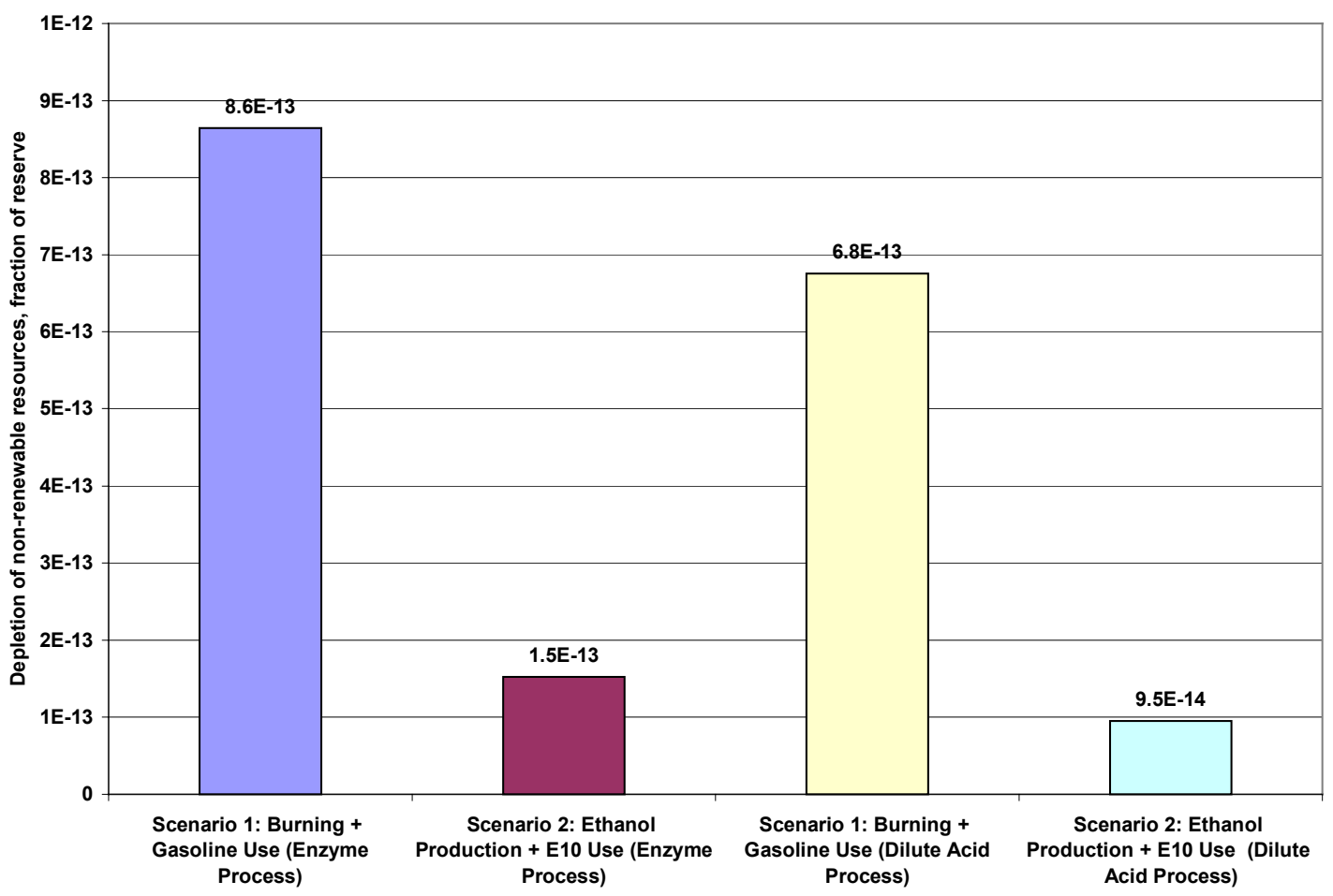

Figure 23. Comparison of burning versus diverting bagasse to ethanol: Depletion of nonrenewable resources. 


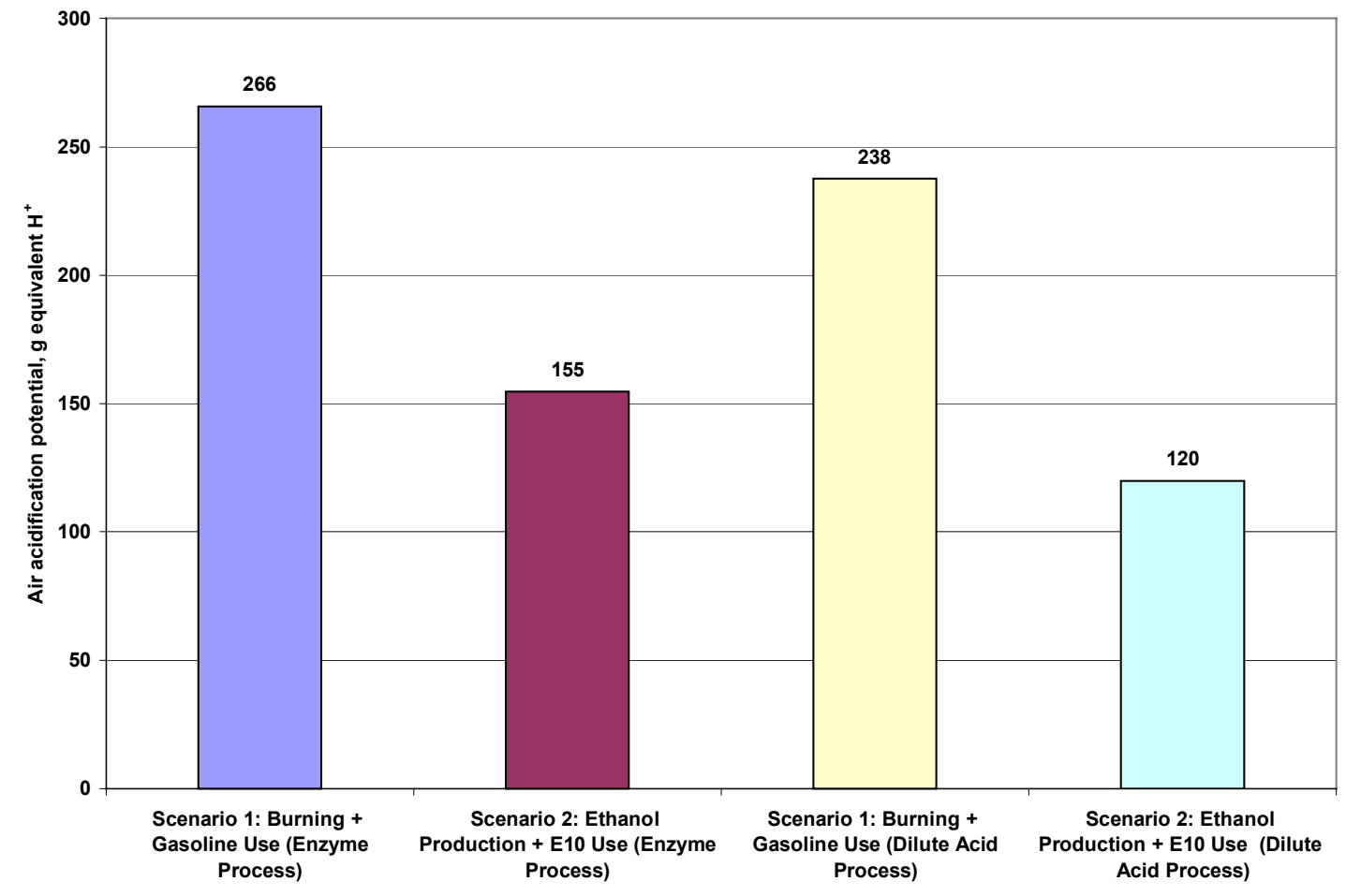

Figure 24. Comparison of burning versus diverting bagasse to ethanol: Air acidification potential.

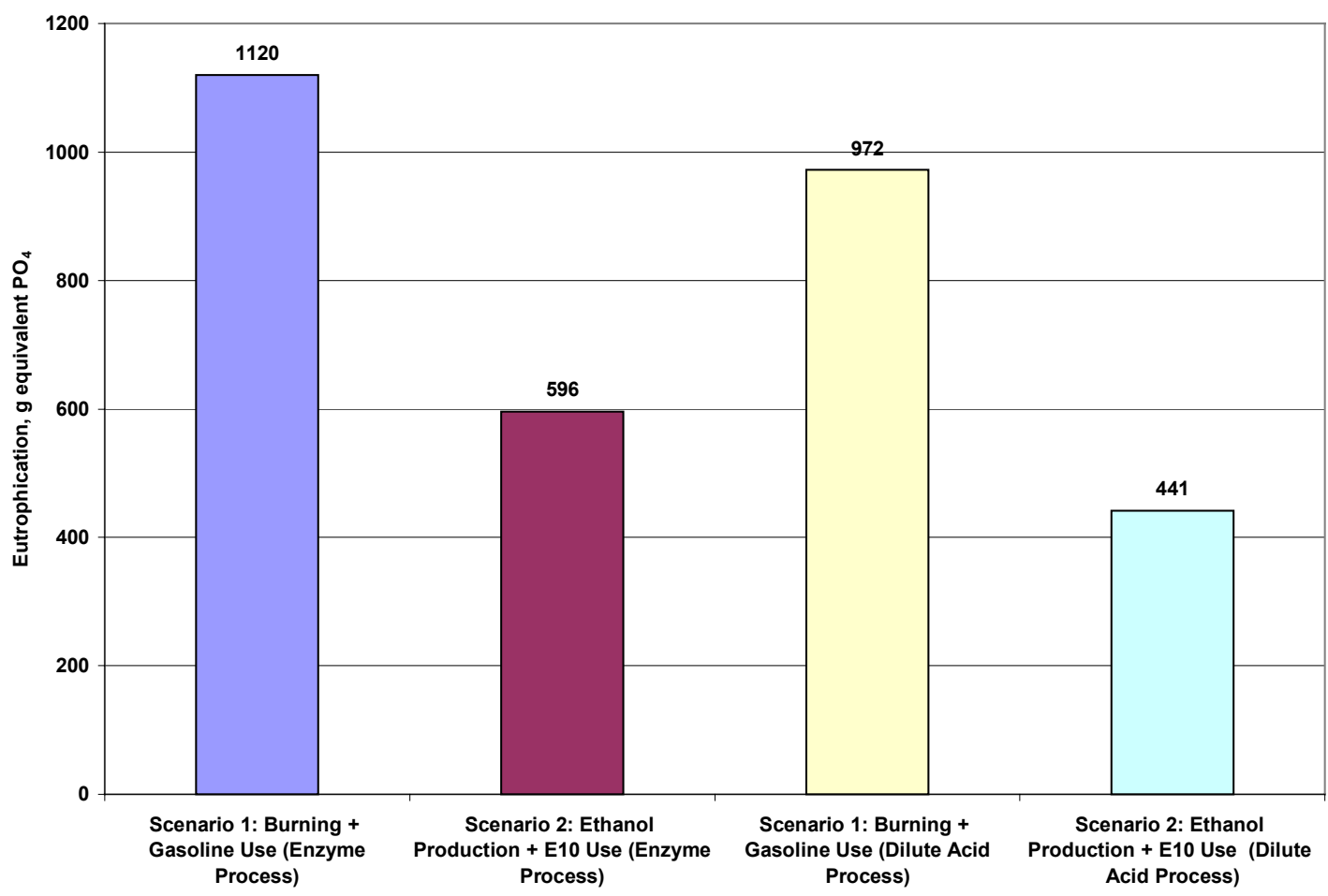

Figure 25. Comparison of burning versus diverting bagasse to ethanol: Eutrophication potential. 


\subsubsection{Human Toxicity Potential}

The human toxicity potential is higher for Scenario 1 than for Scenario 2 (Figure 26). Gasoline production and burning activities in Scenario 1 contribute to its higher index value. This is not unexpected since this impact takes into account all the toxic compounds, both in air and water, and most of these emissions are higher for Scenario 1 than for Scenario 2.

\subsubsection{Air Odor Potential}

Although less obnoxious than the toxic emissions, this impact is also important to consider. The air odor index is higher for Scenario 1 than for Scenario 2 (Figure 27). Again, the burdens from gasoline production and burning in Scenario 1 play a role in its higher index value. Scenario 2 actually has negative index values, meaning that it offsets the odor impact of Scenario 1, and still has credits left in this realm.

\subsubsection{Maximum Incremental Reactivity Potential}

EPA-maximum incremental reactivity (MIR), or ozone-forming potential, as calculated by $\mathrm{TEAM}^{\mathrm{TM}}$, is somewhat higher for Scenario 2 than for Scenario 1. This is because nonmethane hydrocarbon emissions during burning are not speciated and could not be included in these calculations. The EPA-Maximum incremental reactivity potential is calculated by using individual emissions shown in Table 26 (this list includes only those compounds occurring in the processes and/or modules used in the current LCA model). Hence, the ozone impact from burning is not included in the impact for Scenario 1. Thus, it can be surmised that the actual MIR potential, although it cannot be accurately assessed, would be lower for Scenario 2 than for Scenario 1.

Table 26. Ozone-forming potential of selected compounds

\begin{tabular}{lclc}
\hline \multicolumn{1}{c}{ Compound } & $\begin{array}{c}\text { Maximum } \\
\text { incremental } \\
\text { reactivity, } \\
\text { ozone }\end{array}$ & \multicolumn{1}{c}{ Compound } & $\begin{array}{c}\text { Maximum } \\
\text { incremental } \\
\text { reactivity, } \\
\text { ozone }\end{array}$ \\
\hline Acetaldehyde $\left(\mathrm{CH}_{3} \mathrm{CHO}\right)$ & 6.322 & Ethylene $\left(\mathrm{C}_{2} \mathrm{H}_{4}\right)$ & 8.287 \\
Acetone $\left(\mathrm{CH}_{3} \mathrm{COCH}_{3}\right)$ & 0.4892 & Formaldehyde $\left(\mathrm{CH}_{2} \mathrm{O}\right)$ & 7.009 \\
Acetylene $\left(\mathrm{C}_{2} \mathrm{H}_{2}\right)$ & 0.567 & Heptane $\left(\mathrm{C}_{7} \mathrm{H}_{16}\right)$ & 1.045 \\
Benzaldehyde $\left(\mathrm{C}_{6} \mathrm{H}_{5} \mathrm{CHO}\right)$ & -0.259 & Hexane $\left(\mathrm{C}_{6} \mathrm{H}_{14}\right)$ & 1.223 \\
Benzene $\left(\mathrm{C}_{6} \mathrm{H}_{6}\right)$ & 0.601 & Methane $\left(\mathrm{CH}_{4}\right)$ & 0.016 \\
Butane $\left(n-\mathrm{C}_{4} \mathrm{H}_{10}\right)$ & 1.255 & Methanol $\left(\mathrm{CH}_{3} \mathrm{OH}\right)$ & 0.627 \\
Butene $\left(1-\mathrm{CH}_{3} \mathrm{CH} \mathrm{H}_{2} \mathrm{CHCH}\right)$ & 10.68 & Phenol $\left(\mathrm{C}_{6} \mathrm{H}_{5} \mathrm{OH}\right)$ & 1.37 \\
Carbon $\mathrm{Monoxide}_{2}(\mathrm{CO})$ & 0.061 & Propane $\left(\mathrm{C}_{3} \mathrm{H}_{8}\right)$ & 0.577 \\
Ethane $\left(\mathrm{C}_{2} \mathrm{H}_{6}\right)$ & 0.299 & Propionaldehyde $\left(\mathrm{CH}_{3} \mathrm{CH}_{2} \mathrm{CHO}\right)$ & 7.592 \\
Ethanol $\left(\mathrm{C}_{2} \mathrm{H}_{5} \mathrm{OH}\right)$ & 1.622 & Propylene $\left(\mathrm{CH}_{2} \mathrm{CHCH}_{3}\right)$ & 11.14 \\
Ethyl Benzene $\left(\mathrm{C}_{6} \mathrm{H}_{5} \mathrm{C}_{2} \mathrm{H}_{5}\right)$ & 3.11 & Toluene $\left(\mathrm{C}_{6} \mathrm{H}_{5} \mathrm{CH}_{3}\right)$ & 3.154 \\
\hline
\end{tabular}




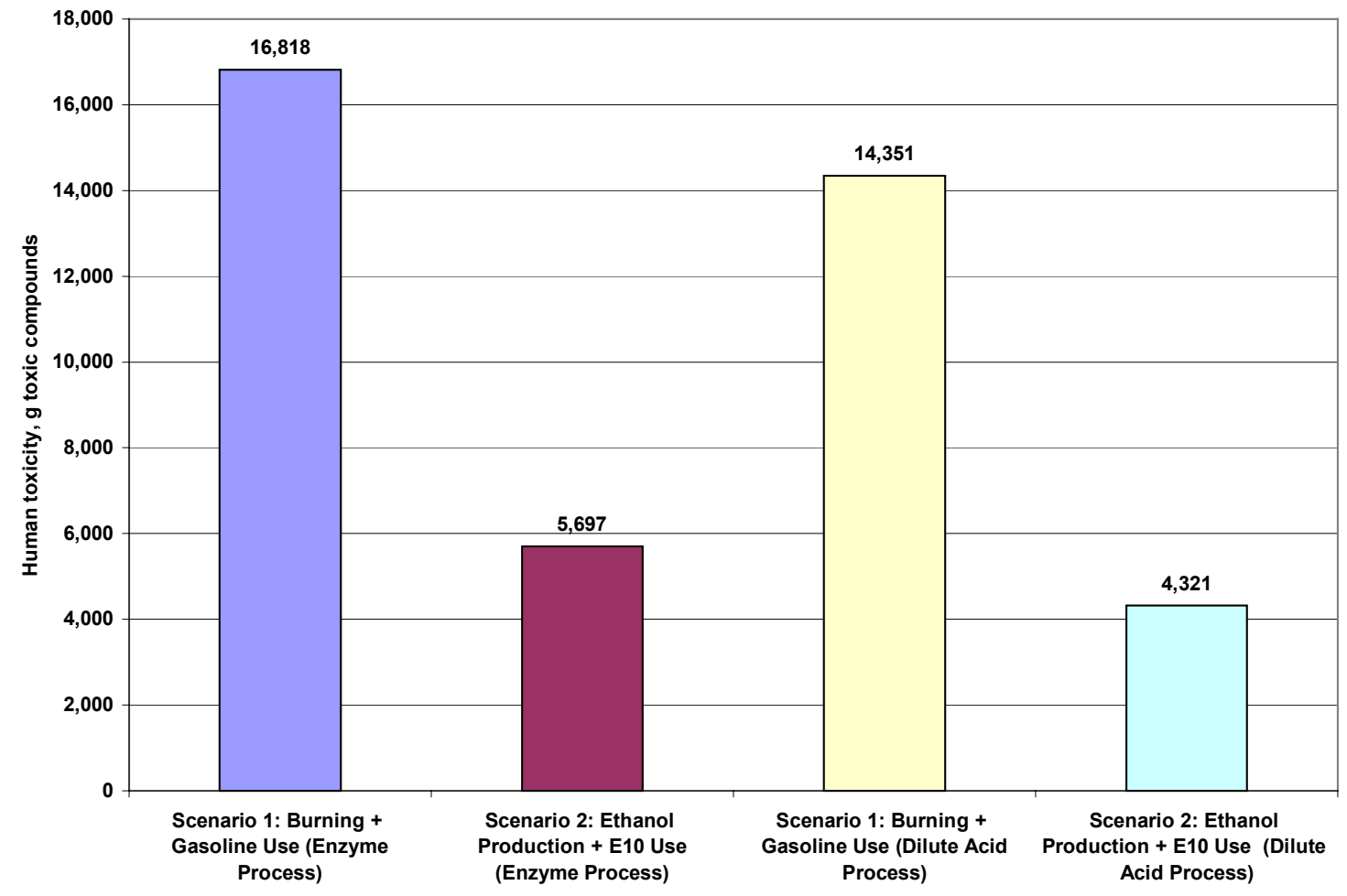

Figure 26. Comparison of burning versus diverting bagasse to ethanol: Human toxicity potential.

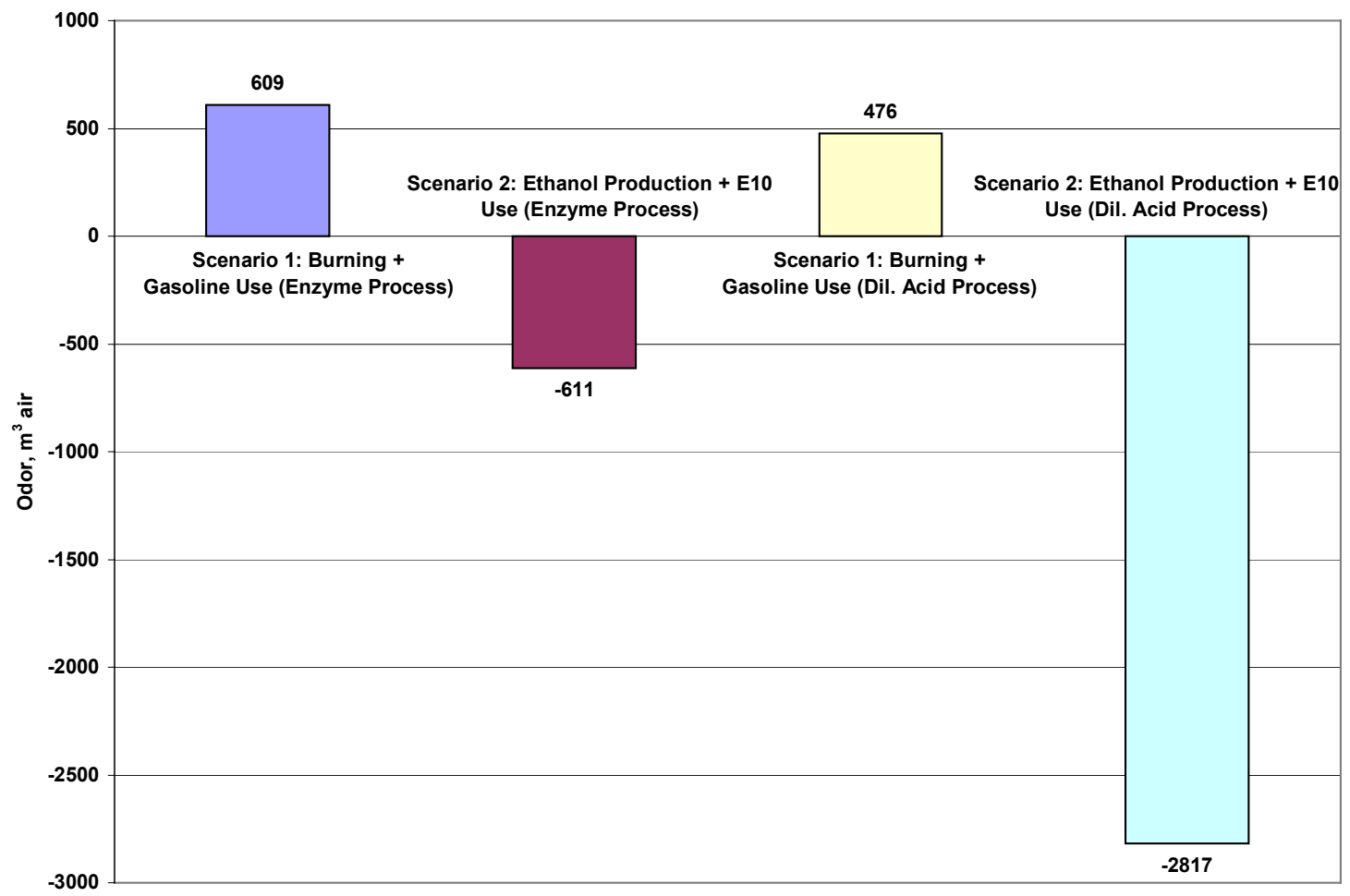

Figure 27. Comparison of burning versus diverting bagasse to ethanol: Air odor potential. 


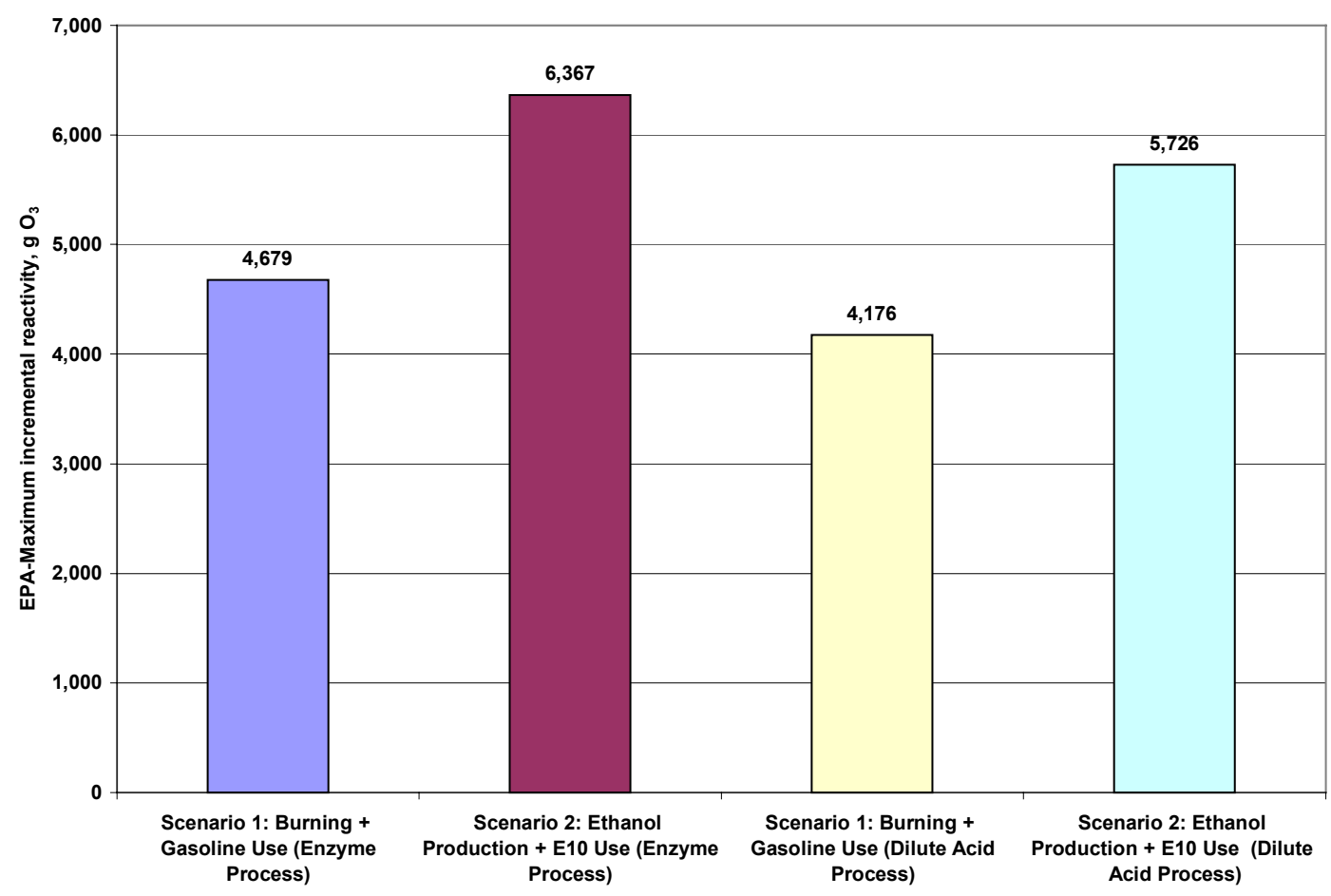

Figure 28. Comparison of burning versus diverting bagasse to ethanol: EPA-Maximum incremental reactivity potential.

\section{Conclusion}

This study provides specific quantitative data on environmental implications of bagasse disposal options in Maharashtra. The LCA performed in this study demonstrates the potentially significant benefits of using ethanol derived from bagasse. Overall, the results show that there is a significant difference between Scenarios 1 and 2 (burning as a disposal option versus conversion to ethanol, respectively); the magnitude of this difference varies with the type ethanol production process. However, in all cases, the comparison of Scenario 1 with Scenario 2 revealed a fundamental difference in energy derived from renewable sources, and the concomitant benefits of reduced greenhouse gas emissions.

Specifically, the prevailing trends observed for the ethanol scenarios were lower net values for:

- $\mathrm{CO}$

- Hydrocarbons (except methane)

- $\mathrm{SO}_{\mathrm{x}}$ and $\mathrm{NO}_{\mathrm{x}}$

- Particulates

- $\mathrm{CO}_{2}$ and methane

- Fossil energy consumption 
Hence, important advantages are associated with the ethanol scenario in regard to reductions in air emissions and energy consumption, and implementation of the ethanol scenario would facilitate air quality improvement. In terms of water phase emissions, however, COD levels were somewhat higher for the ethanol scenario. This is due to the use of ammonia during ethanol fermentation. The lower carbon dioxide and methane emissions, although not regulated or mandated by state or national laws, are desirable attributes. The lower greenhouse potential of Scenario 2 can be important if GHG trading is possible or in the case of JI because India is a developing country.

Additional drivers for the ethanol scenario are the lower values observed for the following six impact assessment categories: eutrophication potential, depletion of natural resources, greenhouse potential, air acidification potential, human toxicity potential, and air odor potential. It should be emphasized that the ethanol scenario shows a lower eutrophication potential despite higher COD values. With properly speciated data, ozone-forming potential can also be shown to be lower for the ethanol scenario.

Hence, the ethanol scenario is shown to commonly exhibit lower burdens than the burning scenario for key environmental criteria, both regulated and unregulated.

\section{Next Phase of the Project}

This study conclusively demonstrates the benefits of diverting the excess bagasse from burning to ethanol production. The next phase should address how to deploy this option in India. The deployment action plan would involve further investigation with the help of relevant parties and stakeholders in India, from both the public and private sectors. These are: the Ministry of Petroleum and National Gas, Indian Institute of Petroleum, Ministry of Surface Transport, Automotive Research Association of India (ARAI), sugar mills associations, potential manufacturers, nongovernmental organizations (NGOs) like USAID and Winrock International, provincial governments, and Petroleum Conservation \& Research Association (PCRA).

There have been recent developments in India that bode well for this opportunity. In March 2000, India's Minister of Petroleum and Natural Gas, Mr. Ram Naik, approved the use of ethanol to reduce detrimental air emissions. Ethanol is to be produced from sugarcane and other agricultural residues such as bagasse and used as an additive to gasoline. (Addresses of several alcohol manufacturers in Maharashtra are listed in Appendix C.) Three pilot projects will be launched in Maharashtra, Uttar Pradesh, and Tamil Nadu. The approval was announced after a seminar entitled, "Ethanol 2000: Sustainable Fuel for the Transport Sector" held in New Delhi. India's Minister for Chemicals and Fertilizers, Mr. Suresh Prabhu, cited applications of ethanol use in the United States, France, Sweden, and Brazil as reasons why the country decided to adopt the use of ethanol. He also said, "One of the most promising strategies is the use of ethanol as a renewable fuel to reduce environmental pollution from India's transport sector while creating new jobs in the rural communities." (Winrock International 2000)

JI and CDM initiatives, and emissions trading are avenues available under the United Nations Framework Convention on Climate Change that can help deploy the renewable fuel option. The World Bank has started a Prototype Carbon Fund (PCF) to address climate change and promote

Environmental Life Cycle Implications of Using Bagasse-Derived Ethanol as a Gasoline Oxygenate in Mumbai (Bombay) 
the transfer of finance and climate-friendly technology to developing countries (World Bank 2000). This is the world's first international market-based emissions trading mechanism $\left(\mathrm{CO}_{2}\right.$, $\mathrm{CH}_{4}, \mathrm{~N}_{2} \mathrm{O}$, hydrofluorocarbons (HFCs), perflourocarbons (PFCs), and sulfur hexaflouride ( $\mathrm{SF}_{6}$ )). A primary focus will be renewable energy technologies - such as wind, small-hydro, and biomass energy technology, which are not profitable without revenue from emissions reductions sold to the PCF.

During his recent trip to India, President Clinton signed a joint statement on cooperation in energy and environment between India and the United States that includes language about the CDM under the auspices of the Kyoto Protocol. Under the agreement, India and the United States will "work together and with other countries in appropriate multilateral fora towards early agreement on the elements in the Kyoto mechanisms, including the Clean Development Mechanisms..." Although officials have not yet resolved some of the details of the CDM, the provision would allow developed countries to receive GHG emission reduction credits for investments made in GHG emission reduction projects in developing countries (IPS 2000).

Hence, these encouraging developments can be exploited in advancing the deployment of the bioethanol option in India. 


\section{LiST OF ACRONYMS AND ABbREVIATIONS}

\begin{tabular}{|c|c|}
\hline ARAI & Automotive Research Association of India \\
\hline CDM & Clean Development Mechanism \\
\hline $\mathrm{CH}_{4}$ & methane \\
\hline $\mathrm{CO}$ & carbon monoxide \\
\hline $\mathrm{CO}_{2}$ & carbon dioxide \\
\hline CSL & corn steep liquor \\
\hline $\mathrm{g}$ & gram \\
\hline $\mathrm{gal} / \mathrm{yr}$ & gallons per year \\
\hline GHGs & greenhouse gases \\
\hline ha & hectare \\
\hline $\mathrm{HMF}$ & hydroxyl-methyl-furfural \\
\hline JI & Joint Implementation \\
\hline $\mathrm{kg}$ & kilogram \\
\hline $\mathrm{kJ}$ & kilojoules \\
\hline $\mathrm{L}$ & liters \\
\hline $\mathrm{L} / \mathrm{yr}$ & liters per year \\
\hline LCA & life cycle assessment \\
\hline LCI & life cycle inventory \\
\hline LCIA & life cycle impact assessment \\
\hline MJ & megajoules \\
\hline $\mathrm{mm}$ & millimeters \\
\hline Mt & million metric tons \\
\hline MTBE & methyl tertiary butyl ether \\
\hline $\mathrm{N}_{2} \mathrm{O}$ & nitrous oxide \\
\hline $\mathrm{NGO}$ & nongovernmental organization \\
\hline $\mathrm{NO}_{\mathrm{x}}$ & nitrogen oxides \\
\hline OECD & $\begin{array}{l}\text { Organization for Economic Cooperation and } \\
\text { Development }\end{array}$ \\
\hline $\mathrm{PCF}$ & Prototype Carbon Fund \\
\hline PCRA & Petroleum Conservation \& Research Association \\
\hline SHF & separate hydrolysis and fermentation \\
\hline $\mathrm{SO}_{\mathrm{x}}$ & sulfur oxides \\
\hline $\mathrm{SSCF}$ & simultaneous saccharification and cofermentation \\
\hline $\mathrm{t}$ & metric ton \\
\hline TPD & metric tons crushed per day \\
\hline TRI & U.S. Toxic Release Inventory \\
\hline EPA & U.S. Environmental Protection Agency \\
\hline USAID & U.S. Agency for International Development \\
\hline VOC & volatile organic compound \\
\hline VSSK & Vasantdada Shetkari Sakhar Karkhana, Ltd. \\
\hline
\end{tabular}




\section{REFERENCES}

Atchison, J.E. (1993). "Bagasse.” In Pulp and Paper Manufacture Series, Vol. 3: Secondary Fibers and Non-Wood Pulping, Hamilton, F.; Leopold, B.; Kocurek, M.; eds., $3^{\text {rd }}$ ed., TAPPI, Atlanta, GA; pp. 22-70.

CARB (November 1998). "Comparison of the Effects of a Fully-Complying Gasoline Blend and a High RVP Ethanol Gasoline Blend on Exhaust and Evaporative Emissions." California Air Resources Board, Sacramento, CA.

Carter, W.P. (1994) "Development of Ozone Reactivity Scales for Volatile Organic Compounds." J. Air \& Waste Manage. Asso., (44), pp. 881-899.

CML (October, 1992). "Environmental Life Cycle Assessment of Products: Guide and Backgrounds." Centre of Environmental Science (CML), Leiden University, The Netherlands.

CRFA (1999). "Emissions Impact of Ethanol." Canadian Renewable Fuels Association, Guelph, Ontario, Canada.

Deccan Herald (1999). "Maharashtra to Crush Only 4.31 Lakh Tonnes of Cane." Deccan Herald, Bangalore, India, March 18, 1999.

Earth Summit Watch (1995). "The Lead Phaseout Page: Phaseout Profile for India." http://gaia1.ies.wisc.edu/research/leadphaseout/welcome.html.

Earth Summit Watch (1999). "The Global Phaseout of Leaded Gasoline: A Successful Initiative." http://earthsummitwatch.org/gasoline.html.

EPA (1985). "Costs and Benefits of Reducing Lead in Gasoline: Final Regulatory Impact Analysis." EPA-230-05-85-006, Office of Policy Analysis, U.S. Environmental Protection Agency, Washington, DC.

EPA (1993a). "Life Cycle Design Manual: Environmental Requirements and the Product System.” EPA/600/R-92/226, U.S. Environmental Protection Agency, Washington, DC.

EPA (1993b). "Life-Cycle Assessment: Inventory Guidelines and Principles." EPA/600-R-92245, U.S. Environmental Protection Agency, Washington, DC.

EPA (1995a). "Guidelines for Assessing the Quality of Life-Cycle Inventory Analysis." EPA/530-R-95-010, U.S. Environmental Protection Agency, Washington, DC.

EPA (1995b). "Emission Factor Documentation for AP-42." Office of Air Quality Planning and Standards, Office of Air and Radiation, U.S. Environmental Protection Agency, Washington, DC.

Guinee, J. B. (1995). A Proposal for the Definition of Resource Equivalency Factors for Use in Product Life-Cycle Assessment in Development of a Methodology for the Environmental Life-Cycle Assessment of Products. Thesis, Centre of Environmental Science (CML), University of Leiden, Netherlands.

Harvey, C.A.; Adler, J. (1988). "Effects of gasoline-oxygenate blends on motor vehicle emissions." Proceedings of the VIII International Symposium on Alcohol Fuels, Tokyo, November 13-16, 1988, Sanbi Insatsu Co. Ltd., Japan.

Heijungs, R.; Guinée, J.B.; Huppes, G.; Lankreijer, R.M.; Udo de Haes, H.A.; Wegener Sleeswijk, A.; Ansems, A.M.M.; Eggels, P.G.; van Duin, R.; de Goede, H.P. (October 1992). "Environmental Life Cycle Assessment of Products." Center of Environmental Science, University of Leiden, Netherlands.

IPCC (1994). "The 1994 Report of Scientific Assessment Working Group of IPCC." International Panel on Climate Change (IPCC), Geneva, Switzerland. 
IPS (2000). “U.S., India Sign Agreement on CDM.” Indian Press Service, March 23, 2000.

ISO (1996). "Draft International Standard ISO/DIS 14040: Environmental management - Life cycle assessment - Principles and framework." International Organization for Standardization, Geneva, Switzerland.

ISO (1997). "Draft International Standard ISO/DIS 14041: Environmental management - Life cycle assessment - Goal and scope definition and inventory analysis." International Organization for Standardization, Geneva Switzerland.

Johnson, D.K.; Adam, P.; Ashley, P.; Chum, H.; Deutch, S.; Fennell, J.; Wiselogel, A. (1992). "Study of compositional changes in biomass feedstocks upon storage (results)." National Renewable Energy Laboratory, Golden, CO.

Kadam, K.L.; Camobreco, V. J.; Glazebrook, B.E.; Forrest, L.H.; Jacobson, W.A.; Simeroth, D.C.; Blackburn; Nehoda K.C. (May 1999). "Environmental Life Cycle Implications of Fuel Oxygenate Production from California Biomass." NREL Report no. NREL/TP-58025688, National Renewable Energy Laboratory Golden, CO.

Lovei, M. (1996). "Phasing Out Lead from Gasoline: World-Wide Experience and Policy Implications." Environment Department Paper No. 40, World Bank, Washington, DC.

Lower, M.E. and Barros, S. (October 1999). "Brazil Sugar Semi-Annual Report 1999." GAIN Report \#BR9022, Sao Paulo, Brazil.

Maharashtra State Government (1998). "Sugar Co-Generation Power Projects." Presented at the Global Investors' Convention: Agro Advantage Maharashtra, November 6-9, 1998, Mumbai, India.

Morris, D.; Ahmed, I. (December 1992). "How Much Energy Does It Take to Make a Gallon of Ethanol?" Institute for Local Self-Reliance, Washington, DC.

NREL (November 1993). "Fuel Cycle Evaluations of Biomass-Ethanol and Reformulated Gasoline.” NREL/TP-463-4950, National Renewable Energy Laboratory (Oak Ridge National Laboratory, and Pacific Northwest Laboratory), Golden, CO.

Rao, P.J.M. (1997). "Industrial Utilization of Sugarcane and Its Co-products." ISPCK Publishers \& Distributors, Delhi, India.

REPSO (July 1998). "Biomass Business Meet at Kolhapur." REPSO Vision, vol. 4, Renewable Energy Projects Support Office (REPSO), Winrock International, New Delhi, India.

SETAC-Europe (1992). "Life-Cycle Assessment." Society of Environmental Toxicology and Chemistry Europe, Brussels, Belgium.

SETAC (1991). "A Technical Framework for Life-Cycle Assessments." Society of Environmental Toxicology and Chemistry, Washington DC.

SETAC (1993a). "A Conceptual Framework for Life-Cycle Impact Assessment." Society of Environmental Toxicology and Chemistry, Washington DC.

SETAC (1993b). "Guidelines for Life-Cycle Assessment: A Code of Practice." Society of Environmental Toxicology and Chemistry, Washington DC.

SETAC (1994). "Life Cycle Assessment Data Quality: A Conceptual Framework." Society of Environmental Toxicology and Chemistry, Washington DC.

Shapori, H.; Duffield, J.; Graboski, M. (July 1995). "Estimating the Net Energy Balance of Corn Ethanol, Economic Research Service." USDA Report \# 721. U.S. Dept. of Agriculture, Washington DC.

Singh, S.K. (April 2000). "India Sugar Annual Report 2000." GAIN Report \#IN0019, U.S. Embassy, New Delhi, India. 
Smouse, S.M.; Staats, G.E.; Rao, S.N.; Goldman, R.; Hess, D. (1998). Promotion of biomass cogeneration with power export in the Indian sugar industry, Fuel Proc. Technol., (54); pp. 227-247.

Taylor, A.B.; Bell, A.J.; Moran, D.P.; Hodgson, N.G.; Myburgh, I.S.; Botha, J.J. (October 1997) "Gasoline/Alcohol Blends: Exhaust Emissions, Performance and Burn-Rate in a MultiValve Production Engine." SAE Paper 961988 presented at the 1996 SAE International Fuels and Lubricants Conference, San Antonio, TX.

USDA (1998). "Major World Crop Areas and Climatic Profiles.” USDA Agricultural Handbook No. 664. U.S. Department of Agriculture (USDA), Washington, DC.

USDOE (1998). "Waste to Ethanol: Ushering in a New Industry." Biofuels News, vol. 1, no. 4, U.S. Department of Energy (USDOE), Washington, DC.

USDOI (1994). "Mineral Commodity Summary 1994." Bureau of Mines, U.S. Department of the Interior, Washington, DC.

Wang, M. (1996). "GREET 1.0 - Transportation Fuel Cycles Model: Methodology and Use." Center for Transportation Research, Energy Systems Division, Argonne National Laboratory, Argonne, IL.

Wang, M.; Saricks, C.; Santini, D (1998). "Fuel-Cycle Fossil Energy Use and Greenhouse Gas Emissions of Corn Ethanol." Paper presented at the $8{ }^{\text {th }}$ Bio-Energy Conference, Madison, Wisconsin, October 5-8, 1998.

Wang, M.; Saricks, C.; Wu, M. (December 1997). "Fuel-Cycle Fossil Energy Use and Greenhouse Gas Emissions of Fuel Ethanol Produced from U.S. Midwest Corn.” Report to the Illinois Department of Commerce and Community Affairs by Center for Transportation Research, Argonne National Laboratory, Argonne, IL.

Wayman, M.; Parekh, S.R. (1990). "Biotechnology of Biomass Conversion." Prentice Hall, Engelwood Cliffs, NJ.

Winrock International (May 1993). "Advancing Cogeneration in the Indian Sugar Industry: Three Mills in Tamil Nadu and Maharashtra." USAID report no. 93-02, Washington, DC.

Winrock International (2000). "Indian Government Approves the Use of Ethanol." Press release, March 20, 2000.

Wooley, R.; Ruth, M.; Sheehan, J.; Majdeski, H.; Galvez, A. (1999). Lignocellulosic Biomass to Ethanol Process Design and Economics, Utilizing Co-current Dilute Acid Prehydrolysis and Enzymatic Hydrolysis: Current and Futuristic Scenarios. NREL Report TP-58026157, National Renewable Energy Laboratory, Golden, Colorado.

World Bank (1998). "Removal of Lead from Gasoline." In "Pollution Prevention and Abatement Handbook," Part II, Environment Department, World Bank, Washington, DC.

World Bank (2000). "World Bank Launches First-of-its-Kind Market-Based Carbon Fund." Press release, Washington, DC, January 18, 2000.

World Bank (2000). "The Sugar Economy." International Task Force on Commodity Risk Management in Developing Countries, World Bank, Washington, DC. 


\title{
Appendix A: Project Review
}

The project was conducted in such a manner as to allow feedback. The Scoping \& Data Summary Document was reviewed by Vince Camobreco and John Sheehan, and their comments were incorporated into the analysis. The draft Final Report (which contained the LCA results, as well as the scoping decisions and data summary) was reviewed by the following panel, comprised of experts specializing in various relevant fields such as biomass/bioenergy, alternative fuels, electricity generation (especially, in India), and LCA.

\author{
Irshad Ahmed \\ Pure Energy Corporation \\ One World Trade Center - \#5301 \\ New York, New York 10048, USA \\ Telephone: 212 938-6923, Fax: 212 839-0383 \\ e-mail: ahmed@pure-energy.com \\ Harish Bhargava ${ }^{4}$ \\ H3 / 1AB, Pluto \\ Hindustan Estates, Kalyani Nagar \\ Pune 411 006, India \\ e-mail: hbhargava@vsnl.com \\ Vince Camobreco \\ Ecobalance Inc. \\ 7101 Wisconsin Ave. \\ Bethesda, Maryland 20814, USA \\ Telephone: 301 657-5943, Fax: 301 657-5948 \\ e-mail: Vincent.Camobreco@us.pwcglobal.com \\ John Sheehan \\ National Renewable Energy Laboratory \\ 1617 Cole Blvd. \\ Golden, Colorado 80401, USA \\ Telephone: 303 384-6136, Fax: 303 384-6877 \\ e-mail: John_Sheehan@nrel.gov \\ D. Vaidyanathan \\ Industrial and Technical Consultancy Organization of Tamil Nadu Ltd. \\ 50-A Greams Road \\ Madras - 600 006, India \\ Telephone: 9144 8225561, Fax: 91448231987 \\ e-mail:dv_itcot@hotmail.com, itcot@vsnl.com
}

\footnotetext{
${ }^{4}$ Was sent a draft for review but did not provide comments.
} 


\section{APPENDIX B: IMPACT ASSESSMENT}

\section{Background}

Only recently has the LCA tool actually been concerned with the impacts on the environment of a system. By definition, the inventory component of an LCA, still the single focus of many LCA studies, is only concerned with the flows generated by the system (either consumed or emitted), and by definition, does not address the impacts on the environment.

In the most straightforward and transparent approach to LCI interpretation, the LCI results may be used $a s$-is to help identify and prioritize opportunities for pollution prevention or increases in material and energy efficiency for processes within the life cycle. A particular advantage of LCI applied in this way is its comprehensiveness. LCAs help detect the shifting of environmental burdens from one life cycle stage to another (e.g., lower energy consumption during use, achieved at the cost of much higher manufacturing energy consumption), or from one media to another (e.g., lower air emissions at the cost of increased solid waste). The subsequent stage, LCIA, addresses the issue of how to translate the flows previously compiled into environmental impacts. Some issues viewed as crucial for LCIA are:

- The amount of additional exposure data that would be needed to model actual impacts (as in human health risk assessment) is technically incompatible with the nature of LCA (several hundreds or thousands of processes connected together, each one generating dozens or hundreds of emissions), and does not correspond to its objectives. It should be recognized that LCA is one environmental management tool among several, and that LCA cannot replace a specific environmental impact analysis for a specific site (see Figure 29).

- Because LCIA aims at assessing potential impacts, LCA should not be considered as a predictive tool for assessing the actual impacts associated with a system, but rather as a tool providing comparative results for the functional unit considered. Moreover, the functional unit has often no reference to time or space considerations (which would be needed for predictive models), but is solely related to the function and performance of a system. As the modeling of environmental impacts improves, potential LCIA models should become more and more precise and integrate crucial notions such as thresholds. (Current approaches are all based on a "less-is-better" approach.) Consequently, inventory data collection requirements could gradually increase with new parameters characterizing emissions' location, flow rate, key attributes of impacted media, etc.

- Existing approaches that result in a limited number of indices are highly controversial. They have been criticized because they do not separate the objective evaluation stage of the environmental impact on scientific grounds from the subjective "valuation" stage in which these impacts are traded off. Using such approaches is very dangerous from an industrial perspective, due to the following reasons.

* It tends to favor short-term arbitrary choices while masking their arbitrary nature behind quantitative approaches, which convey more rigor and objectivity than are truly involved. This is incompatible with industrial long-term investment and product design.

* The choices made might hide pollution displacement from one media to another or from one step to another. In numerous cases, results of inventory or impact assessment have 
been conclusive enough so that no valuation was actually needed. Moreover, very often, the existence of trade-offs is by itself a crucial piece of information.

- For most impact categories, variability and uncertainties about impact potentials make any single numerical "equivalency factor" immediately contradictable and discreditable. Instead, LCIA methods need to be developed in which process data and results are considered in probabilistic terms. As for inventory results, uncertainties should be propagated and communicated to the decision-making audience.

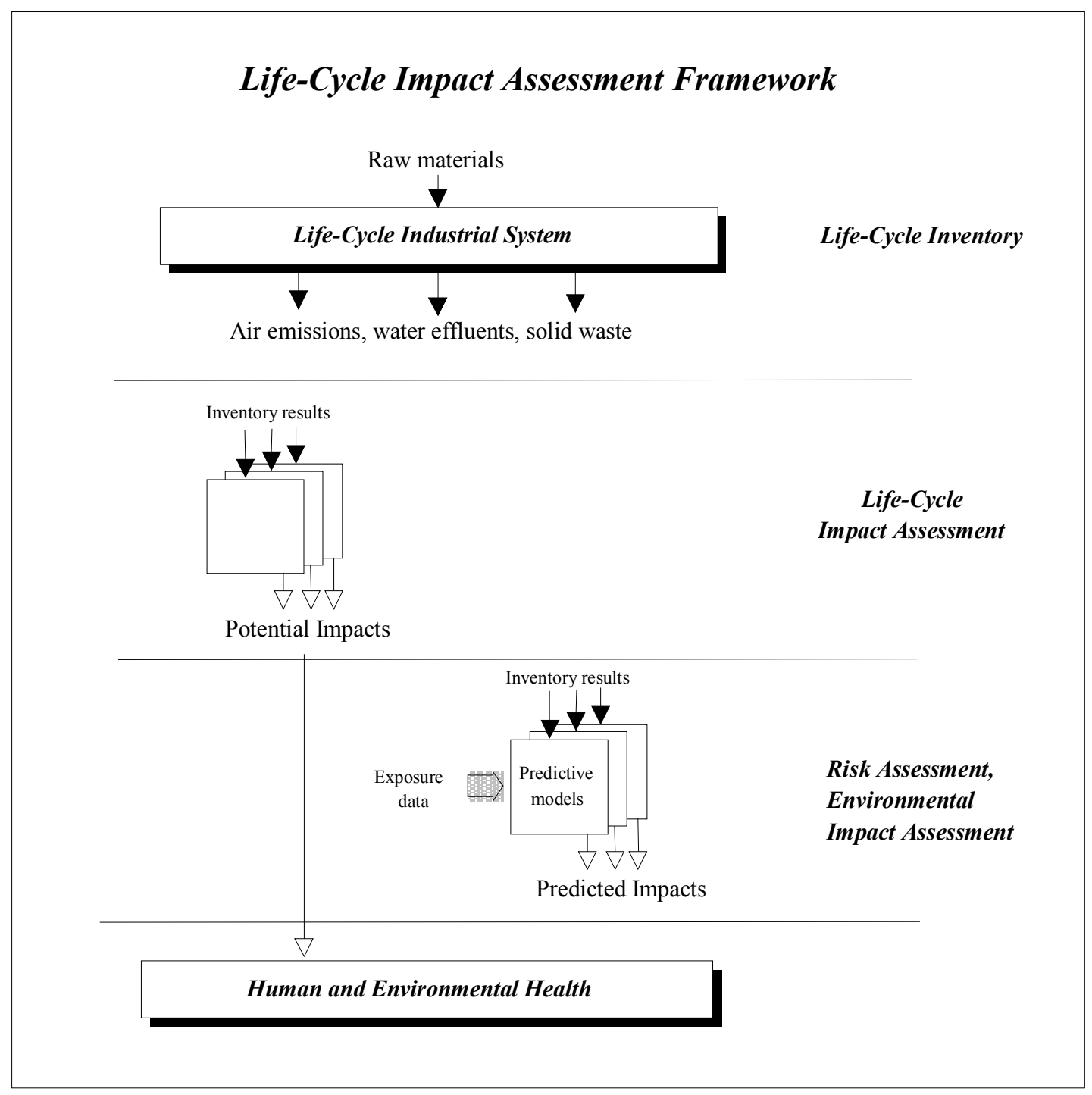

Figure 29. Life cycle impact assessment framework. 


\section{Overview of Life Cycle Impact Assessment Indices}

\section{Greenhouse Potential}

The Greenhouse potential refers to the ability of some atmospheric gases to retain heat that is radiating from the earth. Models have been developed to quantify the contribution made by emissions of various substances to the greenhouse potential. Generally these models provide an indication of the change in the heat radiation absorption of the atmosphere. Global warming potentials (GWPs) have been calculated to compare the emission of different greenhouse gases (IPCC 1994).

The overall result of emission of these gases on the Greenhouse Potential (E) is calculated as follows:

$$
E=\sum G W P_{i} x m_{i}
$$

where, for a greenhouse gas $i$,

$\mathrm{m}_{\mathrm{i}}$ : the mass of the gas released (in $\mathrm{kg}$ ),

$\mathrm{GWP}_{\mathrm{i}}$ : its potential impact on global warming expressed in grams of $\mathrm{CO}_{2}$ equivalent.

The following factors are used to calculate the greenhouse potential (Table 27).

Table 27. Greenhouse gas potential factors

\begin{tabular}{llr}
\hline Formula & Substance & $\mathbf{G W P}_{\mathbf{i}}$ \\
\hline $\mathrm{CO}_{2}$ & Carbon dioxide & 1 \\
$\mathrm{CH}_{4}$ & Methane & 21 \\
$\mathrm{~N}_{2} \mathrm{O}$ & Nitrous oxide & 310 \\
$\mathrm{CCl}_{4}$ & Carbon & 1,400 \\
& tetrachloride & \\
$\mathrm{CFCl}_{3}$ & CFC 11 & 4,000 \\
\hline
\end{tabular}

The potential impact on global warming of the gas $i$ can be defined as the ratio between the cumulative radiative force between the present and a future time horizon (in this case, 20, 100, and 500 years) as a result of the release of a unit mass of greenhouse gas $i$ now, and an equal emission of the standard gas, $\mathrm{CO}_{2}$. The calculation of the GWP is based on understanding the fate of the emitted gas and the radiative effect associated with the amount remaining in the atmosphere.

\section{Acidification Potential}

Potential acidic deposition (onto soil, vegetation, and water) can be expressed as potential $\mathrm{H}^{+}$ equivalents. Potentially acidifying emissions of $\mathrm{SO}_{2}, \mathrm{NO}_{\mathrm{x}}$, and $\mathrm{NH}_{\mathrm{x}}$ can be aggregated on the basis of their potential to form $\mathrm{H}^{+}$. In the calculation of $\mathrm{H}^{+}$equivalents, it is assumed that one 
mole $\mathrm{SO}_{2}$ will produce two moles $\mathrm{H}^{+}$, that one mole nitrogen oxide compounds $\left(\mathrm{NO}_{\mathrm{x}}\right)$ will produce one mole $\mathrm{H}^{+}$, and that one mole reduced nitrogen compounds $\left(\mathrm{NH}_{\mathrm{x}}\right)$ will produce one mole $\mathrm{H}^{+}$.

An acidification potential (AP) of a substance is calculated on the basis of the number of $\mathrm{H}^{+}$ions that can be produced per mole, given by the stoichiometry of the oxidation reaction (Guinee 1995). However, as emissions are specified in $\mathrm{kg}$ rather than in moles, the weight has to be divided by the molecular weight of the substance.

The factors used for AP are listed in Table 28.

Table 28. Acidification potential reactions

\begin{tabular}{llll}
\hline Formula & Substance & \multicolumn{1}{c}{ Reaction } & AP \\
\hline $\mathrm{SO}_{2}$ & Sulfur dioxide & $\mathrm{SO}_{2}+\mathrm{H}_{2} \mathrm{O}+\mathrm{O}_{3} \rightarrow 2 \mathrm{H}^{+}+\mathrm{SO}_{4}{ }^{2-}+\mathrm{O}_{2}$ & 32 \\
$\mathrm{NO}_{\mathbf{x}}$ & Nitrogen oxides & $\mathrm{NO}_{2}+\mathrm{OH}^{-} \rightarrow \mathrm{H}^{+}+\mathrm{NO}_{3}{ }^{-}$ & 46 \\
$\mathrm{NH}_{3}$ & Ammonia & $\mathrm{NH}_{3}+2 \mathrm{O}_{2} \rightarrow \mathrm{H}^{+}+\mathrm{NO}_{3}{ }^{-}+\mathrm{H}_{2} \mathrm{O}$ & 17 \\
$\mathrm{HCl}$ & Hydrochloric acid & $\mathrm{HCl} \rightarrow \mathrm{H}^{+}+\mathrm{Cl}^{-}$ & 36.5 \\
$\mathrm{HF}$ & Hydrogen fluoride & $\mathrm{HF} \rightarrow \mathrm{H}^{+}+\mathrm{F}^{-}$ & 20 \\
\hline
\end{tabular}

\section{Eutrophication Potential}

Eutrophication is the addition of mineral nutrients to the soil or water, which increases production of cell biomass. In both media, the addition of mineral nutrients $(\mathrm{N}$ and $\mathrm{P})$ in large quantities result in generally undesirable shifts in the number of species in ecosystems and a reduction in the ecological diversity. In water, it tends to increase algae growth, that eventually die and sink to the deeper layers of the water body. The decomposition of this dead cell biomass requires the consumption of large amounts of oxygen, which can result in the death of other aquatic species, such as fish.

Another form of oxygen deficit may be caused by emissions of organic materials that can bind oxygen. These emissions are generally expressed as BOD or the COD. The oxygen is mainly consumed by the biological degradation of organic content. The eutrophication potential (EP) of a substance is calculated on the basis of its potential cell biomass formation. It is calculated in $\mathrm{N}$ equivalent, by considering the average ratio of $\mathrm{N}$ and $\mathrm{P}$ in cell biomass and the oxygen required for the breakdown of this cell biomass. The ratios for $\mathrm{N}, \mathrm{P}$, and $\mathrm{O}_{2}$ are 7, 1, and 142, respectively.

EPs are developed by analogy with the GWP. Therefore, phosphate ions have been chosen as the reference substance. A single index is produced for the eutrophication:

$$
E P=\sum E P_{i} \times m_{i}
$$


where $m_{i}$ is the weight (in $\mathrm{kg}$ ) of the substance released. The calculated quantity indicates the quantity of $\mathrm{PO}_{4}$ emission with the same potential eutrophication effect.

The following classification factors (Table 29) are used for the eutrophication potential (CML 1992).

Table 29. Eutrophication potential factors

\begin{tabular}{llc}
\hline Formula & Substance & EP \\
\hline $\mathrm{PO}_{4}$ & Phosphates & 1 \\
$\mathrm{P}$ & Phosphorous & 3.06 \\
$\mathrm{~N}$ & Nitrogen & 0.42 \\
$\mathrm{NO}_{\mathrm{x}}$ & Nitrogen oxides & 0.2 \\
$\mathrm{NH}_{3}$ & Ammonia & 0.42 \\
$\mathrm{COD}$ & Chemical oxygen demand & 0.022 \\
\hline
\end{tabular}

\section{Natural Resources Depletion Index}

Resource Depletion as an Environmental Issue

Resource depletion can be defined as the decreasing availability of natural resources. The resources considered in this impact are fossil and mineral resources, excluding biotic resources and associated impacts such as species extinction and loss of biodiversity. It is important to recognize that what is addressed in this index is the fact that some resources are depleted, not the fact that their extraction from the environment will generate impacts (e.g., methane emissions from coal mining).

\section{Corresponding Inventory Flows}

The assessment of natural resources depletion can only be applied to a subset of the LCI flows called elementary flows, i.e., flows that are directly taken from the environment. A coal consumption of $1 \mathrm{~kg}$ at the power plant gate does not correspond to an elementary flow. Rather, it corresponds to a consumption of approximately $1.03 \mathrm{~kg}$ of coal in the ground, due to the losses in mining, processing, and transportation.

\section{Availability Defined}

The notion of availability can be further defined. Natural resources depletion does not consider the availability within the economy, but rather within the "natural" environment. Excluded from this impact are "economic stocks" such as aluminum from aluminum cans or steel from used car bodies. Therefore, the availability is not measured within the whole economy, but only at the economy-environment "boundary." Furthermore, the availability is concerned with the availability within the primary extraction medium (e.g., iron ore available from the earth's crust) and not within the entire geosphere (which would include iron available in water bodies, atmosphere, plants, landfills, etc.). 


\section{Resource versus Reserve}

Once the concept of availability has been defined, the notion of reserve of a resource needs also to be determined. Through the years, geologists, mining engineers, and others operating in the mineral field have used various terms to describe and classify mineral resources. Known resources can be classified from two standpoints: 1) purely geologic or physicochemical characteristics - such as grade, tonnage, thickness, and depth - of the material in place, and 2) profitability analyses based on costs of extracting and marketing the material in a given economy at a given time. The former constitutes important objective scientific information of the resource and a relatively unchanging foundation upon which the latter economic delineation can be based. For mineral resources, the reserve chosen for this index is the reserve base as defined by the U.S. Bureau of Mines resource (USDOI 1994): "part of an identified" resource that meets specified minimum physical and chemical criteria related to current mining and production practices, including those for grade, quality, thickness, and depth. The reserve base encompasses those parts of the resources that have a reasonable potential for becoming economically available within planning horizons beyond those that assume proven technology and current economics. It includes those resources that are currently economic (reserve), marginally economic (marginal reserves) and currently sub-economic." By including economic and sub-economic considerations, the reserve base falls between the two extremes of economic reserve and ultimate reserve/resource base.

For fossil fuels (including uranium), the reserve chosen is based on information supplied by the World Energy Council (WEC). In order to be consistent with the reserve base used by the U.S. Bureau of Mines, the reserve chosen for fossil fuels has been defined as the addition of the WEC's "proved amount in place" (tonnage in place that has been both carefully measured and has also been assessed as exploitable under present and expected local economic conditions with existing available technology) and "estimated additional reserves recoverable" (quantity of the estimated additional amount in place that might become recoverable within foreseeable economic and technological limits).

It should be noted that what matters most in this impact assessment index is the availability of a relative scale allowing comparisons between resources rather than an estimation of the exact size of what is considered available for use. This is linked to the fact that Impact Assessment as performed within an LCA is of a comparative rather than predictive nature. It aims at assessing the relative potential impacts of different alternatives (i.e., natural resource depletion index of A versus B) rather than assessing the actual impacts of a system onto the environment (as it would be done in traditional risk assessment).

\section{Index Definition}

Once the type of reserve is identified, an index can be defined that will relate an inventory flow with the depletion of that resource. The proposed depletion index uses equivalency factors, i.e., each natural resource consumption recorded in the inventory is multiplied by the resource's weighting factor (or equivalency factor). As described in equation (1) that follows, the total depletion index is then compiled by adding the previous intermediate results for all inventory flows considered.

\footnotetext{
${ }^{5}$ As opposed to identified resources are undiscovered resources, the existence of which is only postulated.
} 
Several methods can be used to produce the equivalency factors. In the first method described in equation (2), the inverse of reserve (in $\mathrm{kg}$ ) is used as a weighting factor. Such an index addresses the relative contribution of the LCA system to the depletion of the reserves (the larger the relative contribution, the bigger the index) as well as the size of the reserve (the larger the reserve, the smaller the index). However, it does not address the following problem: how long a given resource will continue to be available (the fact that the reserve is rapidly or slowly being depleted, which is directly related to the notion of sustainability, is not accounted for in this index).

In the second method, described in equation (3), the inverse of remaining years of use is used as a weighting factor. The number of remaining years of use is defined as the reserves divided by the total world-wide production (i.e., extraction). It represents the number of years for which current reserves will suffice at the current production (extraction) level. This index, however, does not correctly account for the size of the reserve: two resources with the same number of years will have the same indices irrespective of whether there are $1 \mathrm{~kg}$ or 1 million $\mathrm{t}$ reserves.

In the third method described in equation (4) and retained as a basis for the index, the inverse of remaining years of use and the reserve size are used as weighting factors. This index addresses both problems that were raised by the first two methods. It should be noted, however, that choosing higher (e.g. cubic) power for the reserve and production could generate a number of similar indices. ${ }^{6}$ Because there is no rational basis for doing so, the index has been kept as in equation (4). In order to facilitate the readability of the results, all equivalency factors have been multiplied by $10^{15}$. (As explained previously, the relative contribution of each resource is what matters most.)

(1) Depletion $=\sum_{r e s}$ equivalency factor $r_{r e s} x$ inventory consumption $n_{r e s}$

(2) Depletion $=\sum_{\gamma e s} \frac{1}{\text { reserve }} e_{\text {res }} \times$ inventoryconsumption $_{r e s}$

(3) Depletion $=\sum_{\gamma e s} \frac{1}{\text { years }_{r e s}} \times$ inventoryconsumption $_{r e s}=\sum_{r e s} \frac{\text { production }_{r e s}}{\text { reserve }_{r e s}} \times$ inventoryconsumption $_{r e s}$

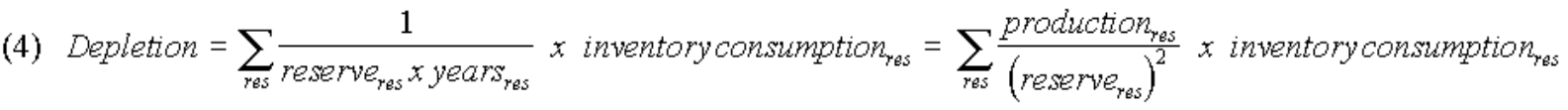

\section{Human Toxicity Index}

Human toxicity potential (HTP), expressed in kg of body weight, is calculated as follows:

$$
H T P=\sum H C A_{i} m A_{i}+\sum H C W_{i} m W_{i}+\sum H C S_{i} m S_{i}
$$

\footnotetext{
6 It has been shown that in order to keep the index independent of the resource density, the power of the reserve should be the power of the production plus one, which is the case in equation (4).
} 
where, for the toxic compound $i$,

$\mathrm{mA}_{\mathrm{i}}$ : the mass (in $\mathrm{g}$ ) of a compound emitted in air, $\mathrm{mS}_{\mathrm{i}}$ : the mass (in $\mathrm{g}$ ) of a compound emitted in soil, $\mathrm{mW}_{\mathrm{i}}$ : the mass (in $\mathrm{g}$ ) of a compound emitted in water, $\mathrm{HCA}_{\mathrm{i}}$ : the toxicological Classification Factor (in kg body weight/g substance) for air emissions, $\mathrm{HCS}_{\mathrm{i}}$ : the toxicological Classification Factor (in kg body weight/g substance) for soil emissions, $\mathrm{HCW}_{\mathrm{i}}$ : the toxicological Classification Factor (in $\mathrm{kg}$ body weight/g substance) for water emissions.

The factors applied to the amounts of substances emitted in the environment are the products of two factors: the exposure factor and the effect factor.

For an emission of a substance $M_{\text {subs,air }}$ in the air:

$$
\begin{gathered}
C_{\text {subs,air }}=\frac{M_{r s u b s, a i r}}{V_{\text {air }}} \\
m_{\text {subs,via_air }}=\frac{M_{\text {subs,air }}}{V_{\text {air }}} V_{\text {air }} \\
T_{\text {subs,via_air }}=\frac{M_{\text {subs,air }}}{V_{\text {air }}} V_{\text {air }} W
\end{gathered}
$$

The exposure factor of a substance emitted in air is independent of this substance and is equal to:

$$
X_{\text {subs,via_air }}=\frac{v_{\text {air }} W}{V_{\text {air }}}
$$

where,

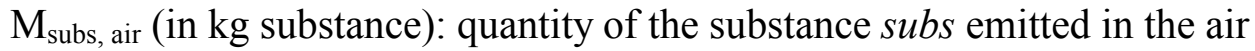

$\mathrm{C}_{\text {subs }}$, air (in $\mathrm{kg}$ substance $/ \mathrm{m} 3$ ): atmospheric concentration of subs

$\mathrm{V}_{\text {air }}\left(\mathrm{m}^{3}\right)$ : total volume of air in the world model $\left(3 \times 10^{8} \mathrm{~m}^{3}\right)$

$\mathrm{V}_{\text {air }}\left(\mathrm{in}^{3} /\right.$ day/person): volume of air inhaled per person per day

$\mathrm{m}_{\text {subs,via_air }}$ (in $\mathrm{kg}$ substance/day/person): total daily human exposure

W (in person): global population

$\mathrm{T}_{\text {subs, via_air }}$ (in $\mathrm{kg}$ substance/day): total daily exposure

$\mathrm{X}_{\text {subs, via } \_ \text {air }}\left(\right.$ in day $^{-1}$ ): exposure factor air 
The calculation for water is analogous to the one for the air, with:

$\mathrm{V}_{\text {water }}\left(\mathrm{m}^{3}\right)$ : total volume of water in the world model $\left(3.5 \times 10^{18} 1\right)$ and $\mathrm{v}_{\text {water }}($ in $1 /$ day/person): volume of water consumed per person per day

The case of soil is different as soil is not directly consumed by human beings. Nevertheless, a parameter $\mathrm{v}_{\text {soil }}$ is introduced: $\mathrm{v}_{\text {soil }}$ is analogous to the volume of air inhaled (per person and per day) or to the human water consumption consumed (per person and per day) and is expressed in $\mathrm{kg}$ soil/kg body weight/day. This parameter was evaluated based on a study carried out by the National Institute of Public Health and Environmental Protection (RIVM) in Bilthoven, The Netherlands). The concentration $\mathrm{C}$ in soil was calculated for a number of substances, which should not be exceeded to not threaten public health. A serious threat to the public health corresponds to a dose for a person equal to the product of TDI x M x N (TDI: Tolerable Daily Intake, in kg substance/kg body weight/day; M: body weight of a person; N: corrective factor).

By analogy with the exposure factors for air and water, this dose (TDI x M x N) may be set equal to $\mathrm{C} \mathrm{x} \mathrm{v}_{\text {soil }}$ where $\mathrm{v}_{\text {soil }}$ is expressed in $\mathrm{kg}$ soil/person/day.

$$
\begin{aligned}
& m_{\text {subs,via_soil }}=T D I \times M \times N=C \times v_{\text {soil }} \\
& v_{\text {soil }}=\frac{T D I \times M \times N}{C} \\
& X_{\text {subs,via_soil }}=\frac{v_{\text {soil }} W}{V_{\text {soil }}}
\end{aligned}
$$

The parameter $\mathrm{v}_{\text {soil }}$ is used as a "quantity of soil consumed by a person during a day." It varies from one substance to another (TDI depends on the substance). As the dose reaching humans is proportional to the quantity emitted, this calculation assumes that the exposure route is independent of the level of emission.

The exposure factor of a substance emitted in soil is equal to:

$$
E_{s}=\frac{1}{T D I}
$$

TDI (in $\mathrm{kg}$ substance/day/kg body weight): tolerable daily intake 
According to the data available, the effect factor for a substance emitted in the air is equal to (in order of preference):

$$
E_{\text {air }}=\frac{M}{T C L \times v_{\text {air }}} \quad \frac{M}{A Q G \times v_{\text {air }}} \quad \frac{1}{T D I} \quad \frac{1}{A D I}
$$

where,

$\mathrm{M}$ (in $\mathrm{kg}$ body weight): body weight of a person

TCL (in $\mathrm{kg}$ substance $/ \mathrm{m}^{3}$ ): acceptable concentration in air

AQG (in $\mathrm{kg}$ substance $/ \mathrm{m}^{3}$ ): air quality guidelines

TDI (in $\mathrm{kg}$ substance/day/kg body weight): tolerable daily intake

ADI (in $\mathrm{kg}$ substance/day/kg body weight): acceptable daily intake

$\mathrm{V}_{\text {air }}$ (in $\mathrm{m}^{3} /$ day/person): volume of air inhaled per person per day

TCL: Set by RIVM. The health effects of continuous daily exposure by inhalation to air polluted to the level of the TCL are assumed to be equivalent to a daily oral dose equal to the TDI of that substance.

AQG: Air Quality Guidelines set by the World Health Organization (WHO).

TDI: Tolerable Daily Intake set by RIVM. The WHO method used for ADI was applied for the harmfulness of a substance for oral exposure.

ADI: Acceptable Daily Intake set by WHO.

It should be noticed that TDI and TCL are calculated by extrapolation of data from animal studies. These data (NOEC, LC50, etc.) are divided by uncertainty factors that vary from one method to another. These factors have no scientific meaning and induce a distortion in the results. When there is no threshold value, for instance, in the case of carcinogenic substances, the maximum tolerable risk is equal to 1 additional cancer per 10,000 individuals exposed.

$$
E_{s}=\frac{1}{T D I}
$$

According to the data available, the effect factor for soil is equal to:

where,

TDI (in $\mathrm{kg}$ substance/day/kg body weight): tolerable daily intake ADI (in $\mathrm{kg}$ substance/day/kg body weight): acceptable daily intake

According to the data available, the effect factor for water is equal to (in order of preference):

$$
E_{w}=\frac{1}{T D I} \quad \frac{1}{A D I}
$$


where,

TDI (in $\mathrm{kg}$ substance/day/kg body weight): tolerable daily intake

ADI (in $\mathrm{kg}$ substance/day/kg body weight): acceptable daily intake

\section{Stratospheric Ozone Depletion Index}

The ozone $\left(\mathrm{O}_{3}\right)$ layer is present in the stratosphere and acts as a filter, absorbing harmful shortwave ultraviolet light while allowing longer wavelengths to pass through. Since the late 1970s, a thinning of the ozone layer over the Antarctic has been observed during the spring, which could amount to up to $80 \%-98 \%$ removal of this layer (the ozone "hole"). This hole over the Antarctic is created by the unique chemistry present over the poles. During the winter, a cyclonic vortex forms over the Antarctic, within which temperatures become very cold (less than $-80^{\circ} \mathrm{C}$ ), which allows the formation of 'polar stratospheric clouds' (PSCs). Most chlorine and bromine (from CFCs and other sources) in the atmosphere are bound in reservoir compounds, which render them inert and unable to affect ozone. However, in the presence of the PSCs, complex reactions occur that release active chlorine and bromine from the reservoir compounds. The addition of ultraviolet light during the spring sets up catalytic reactions involving chlorine and bromine, which result in ozone depletion. As the vortex breaks down, this ozone-depleted air mixes into the rest of the stratosphere. These reactions occur, to a lesser extent, in the Arctic.

A decline in the ozone layer allows more harmful short-wave radiation to reach the earth's surface, potentially causing changes to ecosystems as different flora and fauna have varying abilities to cope with it. There may also be adverse affects to agricultural productivity. Effects on humans can include increased skin cancer rates (particularly the fatal melanoma type) and eye cataracts, as well as suppression of the immune system. Another potential problem is the uncertain effect on the climate.

\section{Index Calculation}

The inventory data assigned to the Tropospheric Ozone Creation Index are the VOCs emitted in the air. However, all the VOCs for which an MIR is available have not been included. Also, in this method, there is no coefficient for chemical families, such as alkanes, halogenated hydrocarbons, alcohols, etc., as well as for hydrocarbons (unspecified). Only very specific pollutants are taken into account.

The overall result of emission of these gases on the MIR index is calculated as follows (Carter 1994):

$E=\sum M I R_{i} \times m_{i}$

where, for a volatile organic compound gas $i$,

$\mathrm{m}_{i}$ : mass of the gas released (in $\mathrm{kg}$ ),

MIR $_{i}$ : its Maximum Incremental Reactivity. 
There are a number of inherent difficulties in calculating VOC reactivities, not the least of which is the nonlinear nature of the reactions in photochemical smog. This is typified by the actions of $\mathrm{NO}_{x}$, which can either form $\mathrm{O}_{3}$ or inhibit its formation, depending on the overall environmental conditions. Additionally, scientists are still not certain of the exact mechanism for ozone formation.

One method that is used to quantify the ozone production potential of various VOCs is the incremental reactivity (IR) scale. This scale gives values for VOCs that indicate the change in ozone caused by adding a small amount of the compound to the emissions, divided by the amount added. More precisely, the incremental reactivity is a function of the product of a VOC's kinetic and mechanistic reactivities:

$$
\mathrm{IR}=\left(\begin{array}{ccc}
\text { kinetic reactivity } & \text { mechanistic reactivity } & \text { mass conversion } \\
\text { (VOcted/VOC emitted }) & \text { (moles O3/mole VOC reacted }) \times(\text { moles VOC/gram VOC })
\end{array}\right.
$$

The kinetic reactivity is a value that is primarily dependent on the VOC's atmospheric rate constants as well as the overall levels of $\mathrm{OH}$ radicals, ozone, or light in the scenario. The mechanistic reactivity is a component of both the compound's reaction mechanism and its efficiency in forming ozone. Because most VOCs are measured in terms of mass, a mass conversion component is added. The resulting value is generally given in terms of moles of $\mathrm{O}_{3}$ formed per gram of VOC emitted.

Obviously the calculation of incremental reactivity values is dependent on an understanding of both reactivity of the VOC and the environmental conditions during the time period studied. Therefore, there are limits to the accuracy of the calculated IR values. All the same, government bodies have generally accepted incremental reactivity values.

In the calculation of IR values, a base mix of organic gases is defined in order to approximate the atmospheric constituents. Different scenarios are then modeled to reflect changes in $\mathrm{NO}_{\mathrm{x}}$ concentrations and VOC emissions, to determine the effects on ozone production. One scenario, which gives the MIR, is modeled using the environmental conditions at which the peak ozone levels are most sensitive to changes in total reactive VOC emissions. Results from the MIR scenario are often preferred, because even if environmental conditions vary widely, the incremental reactivity for the VOC will most likely not be more than that which was determine under MIR.

Officially, the EPA has a policy that ranks volatile organic compounds as being either "negligibly reactive" and "reactive." These rankings are used for regulatory control purposes, but they are based on the reactivity of a compound. The informal policy is that compounds with incremental reactivities less than that for ethane $\left(0.299\right.$ gram $\mathrm{O}_{3}$ per gram VOCs $)$ are considered 'negligibly reactive.' This is not to say that these compounds do not form ozone- they do. However, they just produce ozone at small enough levels that their effect on overall ozone formation is considered to be inconsequential. 


\section{Odor Index}

An odor is a volatile emanation of a substance that triggers an olfactory feeling. Odor is considered a problem when a given concentration of odorous substances is experienced as unpleasant. Whether a smell will be experienced as odor (stench) will depend on the individual exposed to it. However, above a certain emission level all individuals will experience it as an odor.

\section{Index Calculation}

The potential direct odorous effects on individuals ('the Odorous Nuisances') of the emission of 64 'malodorous' substances are considered. The overall results of emission of these gases on the Odorous Nuisances in air $\left(\mathrm{O}_{\text {air }}\right)$, expressed in $\mathrm{m}^{3}$, are calculated as follows:

$$
O_{a i r}=\sum \frac{m_{i, a i r}}{O T V_{i, a i r}}
$$

where, for an odorous gas $i$,

$\mathrm{m}_{\mathrm{i}, \text { air }}$ : mass of the substance $i$ released in air (in $\mathrm{kg}$ ).

OTV $_{\mathrm{i} \text {,air: }}$ Odor Threshold Value in air $\left(\right.$ in $\left.\mathrm{kg} \cdot \mathrm{m}^{-3}\right)$.

The Odor Threshold Value (OTV) of a substance is defined as the concentration of a given substance under defined standard conditions at which $50 \%$ of a representative sample of the population can just detect the difference between a sample of air mixed with that substance and a sample of clean air. Thus, this is a definition at the smell (this term is used for emissions) level not at the odor (or odor nuisance: this term is used for effects) level. Smell can be measured with some objectivity but individual associations become more important for odor (stench). For these reasons odor threshold - in fact smell threshold values - rather than stench threshold values are determined.

Odorous substance concentrations and potential odor nuisances are closely related. However, an odor emission does not necessary mean odor nuisance. An odor emission may or may not lead to potential stench or odor nuisance depending on the dispersion of the substance, chemical conversion, stack height, meteorological conditions and the distance between an emission source and a residential area. The provisional approach for malodorous air is a worst case approach, which does not take into account the dispersal and degradation processes, largely dependent on the substance concerned.

In the longer term, some of these processes could be included in the assessment of odor emissions to quantify the contribution of individual substances emissions to odor nuisances, relative to a reference substance.

For most substances, there is no uniform OTV. Today, many measurement methods are available; the purity of the substances, the rate at which the concentration rises, the number of 
subjects, etc., are also factors that influence the odor threshold value. As a result, the values available show wide differences and heterogeneity between OTVs.

Emissions of potentially malodorous substances to water could also produce malodorous air after evaporation into the atmosphere, but this process is not taken into account. 


\section{APPendix C: List of Alcohol MANufacturers in MAHARashtra}

1) The Andhra Sugars Ltd.

Venkatraypuram, Tanuka, West Godavari Dist: A.P. 534215. Tel: 08819/2911, Fax: 3168.

Capacity: 5,400 TPA. ${ }^{1}$ Contact Person: M. Thimmaraja.

2) Ashok Organics Industries Ltd.

406 Sharda Chambers, 33 New Marine Lines, Mumbai, 400 020. Tel: 2056410, 2089556,

Fax: 2089456.

3) Alembic Chemicals Works Co. Ltd.

Alembic Road Baroda 390 003. Tel: 330550, Fax: 330834

Capacity: 3,000 TPA. J.H. Parikh, Manager-Marketing.

4) Cellulose Products of India Ltd.

National Chambers, 29 Veer Nariman Road, Fort Mumbai 400 023. Tel: 2045598, 4835, Fax: 2043271.

Capacity: $10 \mathrm{MLA}^{2}$ Contact Person: G.D. Kamat, General Manager-Marketing.

5) Kothari Sugars \& Chemicals Ltd.

Kothari Building, 115, Mahatma Gandhi Salai, Chennai, 600 034. Tel: 8276036, 4901, 4892 , Fax: 8272263.

Capacity: 9 MLA. Contact Person: V. Ramchandran.

6) Krishna Sahakari Sakhar Karkhana Ltd.

Rethare Budruk, P.O. Shivnagar, Karad Dist: Satara 415 108. Tel: Karad 2306, Shivnagar $6222,6226$.

Capacity: 4.4 MLA. Contact Person: R.T. Bhosale.

7) Somaiya Organics (India) Ltd.

Narang house, 34, Cht. Shivaji Maharaj Marg, Mumbai 400 039. Tel: 2022934, 2852534,

Fax: 2873646.

Capacity: 600 TPA. Contact Person: K.S. Prasad.

8) Synthetics \& Chemicals Ltd.

Oriental House, 7 J Tata Road, Mumbai 400 020. Tel: 220161, Fax: 2870299. Capacity: 30

MLA. Contact Person: Ketan/Varshal Krishnakant Parikh.

9) Kesar Enterprises Ltd.

Tel: 2042396, 2851737, Fax: 2876162.

Capacity: 14.3 MLA. Contact Person: S.S. Bhatia.

10) United Co-operative Distillery Ltd.

Parite, Shahunagar, Parite Karvir Dist. Kolhapur 416211, Tel: 5630.

Capacity: 4.5 MLA. Contact Person: P.G. Meghe. 
11) Vijayshree Chemicals (India) Ltd. 201, Arvind Chambers, Sai Service Compound, W.E. Highway, Andheri (E), Mumbai 400 069. Tel: 8385304, 4984, Fax 8384984.

Contact Person: K. Chaturvedi.

12) Tilak Nagar Industries Ltd.

Industrial Assurance Building, Churchgate, Mumbai 400 020. Tel: 2831716/8, Fax: 2046904. Capacity: 6 MLA, Contact Person: V.K. Nagle.

13) Sanjivani (Takli) S.S.K. Ltd.

Sahajanandnagar. P.O. Shingnapur Tal. Kopargaon Dist. Ahmadnagar 423 603. Tel: 2334, 2305, Fax: 0242324208.

Capacity: 65,000 liters per day. Contact Person: A.D. Antre.

${ }^{1}$ TPA: metric tons per annum

${ }^{2}$ MLA: million liters per annum 


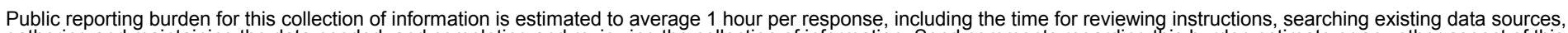

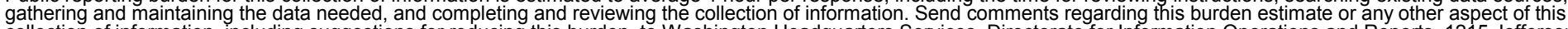

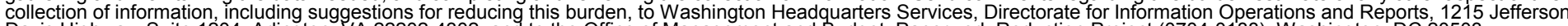

Davis Highway, Suite 1204, Arlington, VA 22202-4302, and to the Office of Management and Budget, Paperwork Reduction Project (0704-0188), Washington, DC 20503.
1. AGENCY USE ONLY (Leave blank)
2. REPORT DATE
November 2000
3. REPORT TYPE AND DATES COVERED
Technical Report

4. TITLE AND SUBTITLE

Environmental Life Cycle Implications of Using Bagasse-Derived Ethanol as a Gasoline

Oxygenate in Mumbai (Bombay)

5. FUNDING NUMBERS

WG88.0101

6. $\operatorname{AUTHOR}(\mathrm{S})$

Kiran L. Kadam

7. PERFORMING ORGANIZATION NAME(S) AND ADDRESS(ES)

8. PERFORMING ORGANIZATION REPORT NUMBER

9. SPONSORING/MONITORING AGENCY NAME(S) AND ADDRESS(ES)

National Renewable Energy Laboratory

1617 Cole Blvd.

AGENCY REPORT NUMBER

NREL/TP-580-28705

Golden, CO 80401-3393

11. SUPPLEMENTARY NOTES

12a. DISTRIBUTION/AVAILABILITY STATEMENT

National Technical Information Service

12b. DISTRIBUTION CODE

U.S. Department of Commerce

5285 Port Royal Road

Springfield, VA 22161

13. ABSTRACT (Maximum 200 words)

Bagasse is the fibrous residue generated during sugar production and can be a desirable feedstock for fuel ethanol production. About $15 \%-25 \%$ of the bagasse is left after satisfying the mills' energy requirements, and this excess bagasse can be used in a bioconvesion process to make ethanol. It is estimated that a 23 million L/yr ( $\sim 6 \mathrm{million}$ gal/yr) ethanol facility is feasible by combining excess bagasse from three larger sugar mills in Maharashtra state. The plant could supply about half of the ethanol demand in Mumbai, assuming that all gasoline is sold as an E10 fuel, a blend of $90 \%$ gasoline and $10 \%$ ethanol by volume.

The life cycle assessment (LCA) performed in this study demonstrated the potentially significant benefits of diverting excess bagasse in Maharashtra to ethanol production, as opposed to disposing it by burning. In particular, lower net values for the ethanol production scenario were observed for the following: fossil energy consumption, and emissions of carbon monoxide, hydrocarbons (except methane), $\mathrm{SO}_{\mathrm{x}}, \mathrm{NO}_{\mathrm{x}}$, particulates, carbon dioxide, and methane. The lower greenhouse potential of the ethanol scenario is also important in the context of Clean Development Mechanism and Joint Implementation because India is a developing country.

14. SUBJECT TERMS

Bagasse, Mumbai, Bombay, sugarcane, India, fuel ethanol, life cycle assessment

17. SECURITY CLASSIFICATION OF REPORT Unclassified
18. SECURITY CLASSIFICATION OF THIS PAGE Unclassified
19. SECURITY CLASSIFICATION OF ABSTRACT Unclassified
15. NUMBER OF PAGES

16. PRICE CODE

20. LIMITATION OF ABSTRACT UL 